Portland State University

PDXScholar

$1-1-1984$

\title{
Evaluating urban containment programs
}

Arthur C. Nelson

Portland State University

Follow this and additional works at: https://pdxscholar.library.pdx.edu/open_access_etds

Let us know how access to this document benefits you.

Recommended Citation

Nelson, Arthur C., "Evaluating urban containment programs" (1984). Dissertations and Theses. Paper 546. https://doi.org/10.15760/etd.546

This Dissertation is brought to you for free and open access. It has been accepted for inclusion in Dissertations and Theses by an authorized administrator of PDXScholar. Please contact us if we can make this document more accessible: pdxscholar@pdx.edu. 


\section{EVALUATING URBAN CONTAINMENT PROGRAMS}

by

ARTHUR C. NELSON

A dissertation submitted in partial fulfillment of the requirements for the degree of

Doctor of Philosophy

in

Urban Studies

Portland State University

(C) 1984 Arthur C. Neison 
TO THE OFFICE OF GRADUATE STUDIES AND RESEARCH:

The members of the Committee approve the dissertation of Arthur C. Nelson presented December 13, 1983.
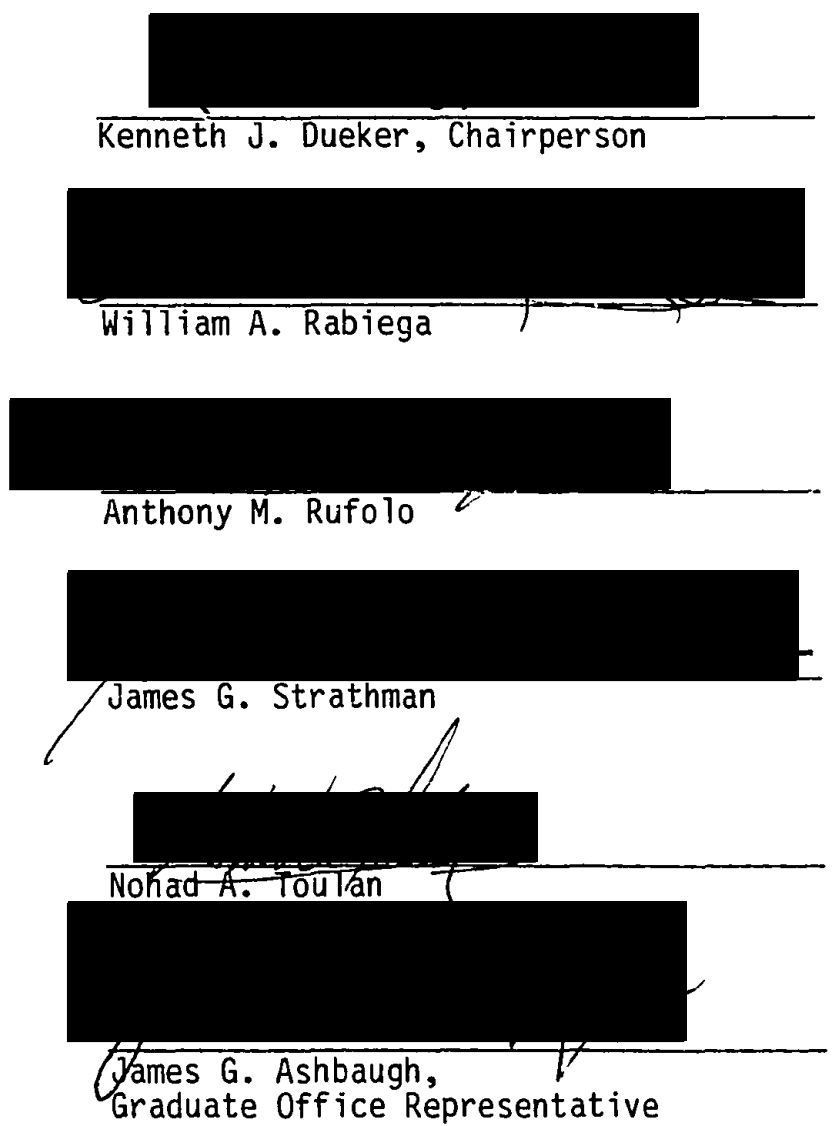

Approved:
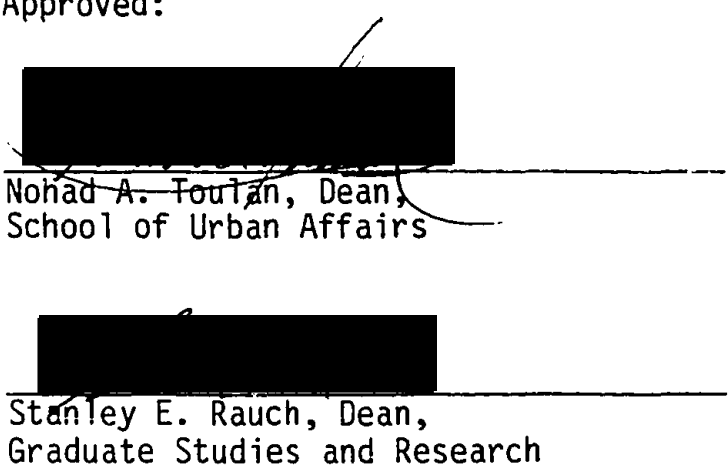
AN ABSTRACT OF THE DISSERTATION OF Arthur C. Nelson for the Doctor of Philosophy in Urban Studies presented December 13, 1983.

Title: Evaluating Urban Containment Programs

APPROVED BY MEMBERS OF THE DISSERTATION COMMITTEE:
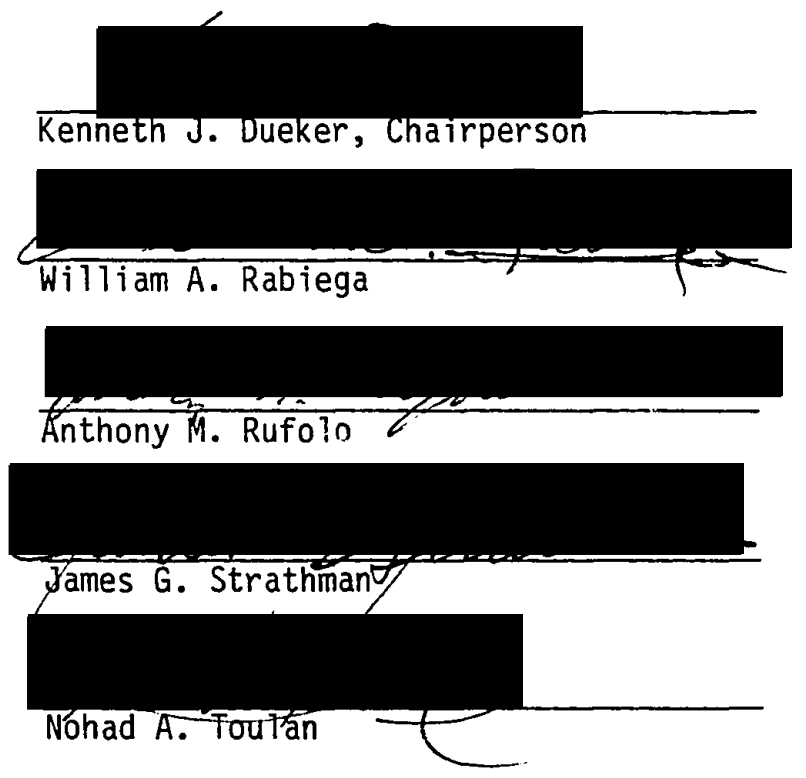

Urban containment programs may be evaluated in terms of a theory unifying contributions from the economic, geographic and political science disciplines. The unified theory shows that successful programs will segment the urban-rural land market, remove speculative use value of rural land, and result in the urban land market valuing greenbelt proximity as an amenity.

A general model to test urban containment programs against the unified theory is developed and then modified for application to Salem, Oregon. Results are fourfold. First, a gap in the locus of 
urban and rural land values at the UGB indicates that segmentation of the urban-rural land market is associated with urban containment policies. Second, the simultaneous effect of imposing a UGB proximate to urban development and subjecting rural land to conservancy zoning is to remove the speculative value component of rural land and reveal Sinclair's (1967) underlying convex quadratic agricultural use land value gradient. This finding is important in two respects: (a) it confirms the possibility of Sinclair's gradient, which has not been supported empirically hitherto, and (b) it suggests that a program's success in preserving greenbelt land solely for agricultural uses can be evidenced if Sinclair's gradient is revealed. Third, the conditions under which a program may fail to preserve rural land from speculative behavior will be evidenced by the traditional negatively sloping land value gradient. Fourth, where urban development is proximate to a UGB delineating greenbelts, the urban land market will value its proximity as an amenity. This finding is important in two respects: (a) it suggests that proximity to privately owned greenbelts may be valued as an amenity in the urban land market, a finding which has not been reported empirically hitherto, and (b) if an urban land market has confidence in the ability of an urban containment program to prevent sprawl into greenbelts, then it will treat greenbelt proximity as an amenity. The unified theory and methodology developed by this dissertation are generalizable to the evaluation of other urban containment jrograms. 


\section{Acknowledgments}

Many acknowledgments are in order. Several individuals assisted in my data collection, especially with regard to determining data availability and peculiarities. Notable among these individuals are Jeannie Sasaki of the Marion County Department of Assessment and Taxation, and Spencer Powell and John Totten of Spencer, Totten \& Associates, Appraisers. Several committee members assisted in my research design, data analysis and interpretation, namely, Kenneth $\mathrm{J}$. Dueker, William A. Rabiega, Anthony M. Rufolo, and especially James G. Strathman. While this dissertation was initially outlined in 1977, data availability made its preparation impractical until recently. Once data became available, however, I would not have had the means to pursue this dissertation were it not for a Maurie D. Clark fellowship. Through this entire period of time, my wife, Monika Zimmermann, has provided me with purposeful review of my work, in addition to sparing my time of many household and business concerns. 


\section{Table of Contents}

Acknowledgments $\quad$ ii i

List of Tables vi

List of Figures vii

List of Plates viji

Introduction 1

Chapter 1. Perceptions of Urban Spraw1 and Oregon's Efforts to Contain it

A. Some Important Roles of Urban Containment Programs 8

1. Reducing the Costs of Sprawl 9

2. Preserving Open Spaces and Related Public Goods and Amenities

3. Removing Speculative Use Value of Rural Land 15

B. Urban Containment Programs Influencing Oregon's Efforts 18

1. The British Example 18

2. American Examples 19

3. The Salem Example 20

4. Oregon's Statewide Urban Containment Efforts 23

Chapter 2. A Unified Theory of Urban Containment Influences on Urban-Rural Land Values

A. Segmenting the Urban-Rural Fringe Land Market 27

B. Removing Speculative Use Value of Rural Land 31

1. Land Value Theory

2. The Use of Urban Containment Programs to Reveal Sinclair's Agricultural Use Land Value Gradient 40

C. Greenbelt Proximity as an Amenity in the Urban Land Market

D. Unifying These Theories

Chapter 3. A Model to Evaluate Urban Containment Programs 50

A. A General Model 50

B. Research Setting and Data Characteristics 52

C. Model Specification and Performance Expectations 57

1. Attribute Specification 59

2. Modelling and Specification Comments 70

3. Choice of Functional Form 72

4. Expected Results 73 
Chapter 4. Results and Interpretations 75

A. Market Segmentation 75

B. Spatial Influences of Containment Policies
on Rural Land Values

1. Removing Farmland Speculation in Rural North Salem 80

2. Maintaining Low Density Sprawl in Rural South Salem 82

C. Spatial Influences of Containment Policies on Urban Land Values 84

1. Greenbelt Proximity as an Amenity in Urban North Salem 86

2. Disequilibrium in Urban South Salem? 89

Chapter 5. Conclusions and Policy Implications 91

1. Urban-Rural Market Segmentation 92

2. Rural Submarket Effects 96

3. Urban Submarket Effects 98

4. A Planning Suggestion 100

$\begin{array}{lr}\text { Selected Bibliography } & 103\end{array}$

Appendix: Supplemental Information $\quad 115$

Chow Tests 116

$\begin{array}{ll}\text { Chow Test Regressions: } & 117 \\ \text { All Cases } & 118\end{array}$

Urban Cases $\quad 118$

Rural Cases 119

Regressions for Urban and Rural Chow Tests:
Rural Cases

\begin{tabular}{ll} 
Urban Cases & 120 \\
\hline
\end{tabular}

$\begin{array}{cc}\text { Means and Standard Deviations of Regressions } & 122 \\ \text { Reported in Text } & 122\end{array}$

Correlation Matrices:
All Cases

All Rural Cases 123

All Urban Cases 123

$\begin{array}{ll}\text { Rural North } & 124\end{array}$

$\begin{array}{ll}\text { Rural South } & 124\end{array}$

Urban North $\quad 125$

Urban South 125

$\begin{array}{cc}\text { Casewise Plots of Standardized Residuals: } & 125 \\ \text { All Cases } & 126\end{array}$

$\begin{array}{ll}\text { Rural North } & 129\end{array}$

Rural South 130

Urban North 131

$\begin{array}{ll}\text { Urban South } & 131\end{array}$

$\begin{array}{ll}\text { Semi-Log Regression Equations: } & 132 \\ \text { All cases } & 133\end{array}$

$\begin{array}{ll}\text { Rural North } & 133 \\ \text { Rural South } & 134\end{array}$

$\begin{array}{ll}\text { Rural South } & 135\end{array}$

Urban North 136

$\begin{array}{ll}\text { Urban South } & 137\end{array}$ 


\section{LIST OF TABLES}

Table

Page

1.1 Population and Land Area of U.S. Urbanized Areas: $1960-1970$

1.2 Urbanization in the Willamette Valley: $1966-2000$

5

3.1 Expected Direction of Associations Between Attribute Coefficients and Price Per Acre 


\section{LIST OF FIGURES}

Figure

Page

2.1 Effecting Segmentation of the Urban-Rural Land Market

2.2 The Competition for Location Between Peas and Wheat

2.3 The Family of Bid-Rent Curves for a User of Land 34

2.4 Distribution of Activities on the Urban Landscape 35

2.5 The Effect of Changing Tastes for Residential Land on the Location of the Urban-Rural Boundary

2.6 The Market Value and Agricultural Use Value of Land Proximate to Urban Development

2.7 Greenbelt Proximity as an Amenity in the Urban Land Market

2.8 The Unified Theory of the Effects of Urban Containment Programs on Urban-Rural Land Values

4.1 Segmentation of the Urban-Rural Fringe Land Market 78

4.2(a) Revealing the Agricultural Use Land Value Gradient in Rural North Salem

4.2(b) Maintaining Urban Land Value Characteristics in Rural South Salem

4.3 Greenbelt Proximity as an Amenity in Urban North Salem

5.1 Effects of an Urban Containment Program on Urban and Rural Land Values 


\section{LIST OF PLATES}

Plate

Page

1.1 Spatial Development of Salem, Oregon, 1900 to 1975.

23

1.2 Location of Salem and its Urban Area in Oregon and within the Mid-Willamette Valley 24

3.1 Marion County Land Use Plan Map, Salem Area 54

3.2 Extent of Urban Development in Salem, Oregon, 197958 


\section{Introduction}

In 1973, Oregon's iejislature adopted its nationally acclaimed statewide land use planning program, which requires every city, county, and regional governing body to prepare comprehensive plans consistent with as many as nineteen planning goals. In recognition of Oregon's pioneering efforts, the American Planning Association bestowed its highest planning honor on Oregon in 1982. Analysts tend to agree that Oregon's planning program rests on two cornerstones: (1) the containment of urbanization within urban growth boundaries (LGBs) and (2) the preservation of farmland solely for farm uses. In the first regard, Oregon's planning program specifically intends to segment the urban-rural fringe land market into distinctive urban and rural submarkets, which is largely accomplished by limiting urban services and urban development to land within a UGB. Second, because the majority of the state's growth occurs in the fertile Willamette Valley, Oregon's program specifically intends to protect this farmland from speculators. This is largely accomplished by imposing exceedingly restrictive "exclusive farm use" (EFU) zoning on prime agricultural farmland proximate to urban areas, and this also has the effect of creating a system of greenbeits between urban areas. Hitherto, empirically sound research demonstrating the performance of Dregon's planning efforts in these regards has not been reported; such work is apparently flawed for want of adequate theoretical or empirical bases. This dissertation provides planning analysts with a theoretical and methodological basis by which to evaluate the influence of urban containment programs on urban-rural land behavior. 
Chapter 1 opens by presenting some of the popular sentiments about urban sprawl expressed during legislative deliberations on the Oregon Land Use Act of 1973. The chapter then reviews the urban containment and farmland preservation literature. This exercise led this researcher to determine the apparent objective embraced by Oregon's program: the manipulation of urban-rural land behavior in order to (1) focus growth into delineated urban areas, even at the expense of creating an excessive demand for urban land; (2) eliminate speculative or non-agricultural use land value of rural 1and; and (3) preserve the several public good and amenity values which greenbelts offer to urban residents. The chapter concludes with a summary of notable urban containment programs apparently influencing the nature of Oregon's efforts, including those of Great Britain, some American cities, generally, and Salem, Oregon, particularly.

Chapter 2 develops a theory describing the effect of urban containment programs on the behavior of the urban-rural land market. This theory borrows from and unities the reievant, but hitherto unrelated, theories of land economics, geography and planning. The unified theory provides the basis for constructing a model to evaluate urban containment programs in Chapter 3. Because Salem is considered by many to be Oregon's, if not America's, quintessential urban containment program, it provides a convenient setting in which to apply the model; the results of this exercise are reported in Chapter 4. Short and long term policy implications for Salem's program particularly, and urban containment programs generally, are offered in Chapter 5. 
CHAPTER 1

\section{Perceptions of Urban Sprawl and Oregon's Efforts to Contain it}

During the 1960s, America's urban population increased by about 20 million; four-fifths of this growth occurred within the urban fringe. During this period, "urban sprawl" consumed land at a pace nearly 70 percent greater than population growth: while total urban population increased by 21 percent, the consumption of land for urban uses increased by 36 percent. Between 1960 and 1970, the volume of urban fringe land increased by nearly 9,000 square miles. These findings are summarized in Table 1.1.

Table 1.1

POPULATION AND LAND AREA OF U.S. URBANIZED AREAS: 1960-1970*

\begin{tabular}{|c|c|c|c|c|c|}
\hline Area & $\begin{array}{l}\text { Number of } \\
\text { Persons }\end{array}$ & $\begin{array}{l}\% \text { of } \\
\text { Total }\end{array}$ & $\begin{array}{l}\text { Square } \\
\text { Miles }\end{array}$ & $\begin{array}{l}\text { \% of } \\
\text { Total }\end{array}$ & $\begin{array}{l}\text { Pers/ } \\
\text { Sq.Mi. }\end{array}$ \\
\hline $\begin{array}{c}1970 \\
\text { All Urban Areas } \\
\text { Central Areas } \\
\text { Fringe Areas } \\
1960\end{array}$ & $\begin{array}{r}115,585,727 \\
61,716,128 \\
53,869,599\end{array}$ & $\begin{array}{c}100.0 \% \\
53.4 \\
46.6\end{array}$ & $\begin{array}{l}33,847.5 \\
13,456.2 \\
20,391.3\end{array}$ & $\begin{array}{c}100.0 \% \\
39.8 \\
60.2\end{array}$ & $\begin{array}{l}3, \frac{115}{115} \\
4,586 \\
2,642\end{array}$ \\
\hline $\begin{array}{l}\text { A11 Urban Areas } \\
\text { Central Areas } \\
\text { Fringe Areas } \\
\text { Change } 1960-70\end{array}$ & $\begin{array}{l}95,834,2.51 \\
57,966,093 \\
37,868,158\end{array}$ & $\begin{array}{r}100.0 \\
60.5 \\
39.5\end{array}$ & $\begin{array}{l}24,978.5 \\
10,534.6 \\
14,443.9\end{array}$ & $\begin{array}{r}100.0 \\
42.2 \\
57.8\end{array}$ & $\begin{array}{l}3,837 \\
5,502 \\
2,622\end{array}$ \\
\hline $\begin{array}{l}\text { All Urban Areas } \\
\text { Central Areas } \\
\text { Fringe Areas }\end{array}$ & $\begin{array}{r}19,751,476 \\
3,750,035 \\
16,001,441\end{array}$ & $\begin{array}{r}20.6 \\
6.5 \\
42.3\end{array}$ & $\begin{array}{l}8,869.0 \\
2,921.6 \\
5,947.4\end{array}$ & $\begin{array}{l}35.5 \\
27.7 \\
41.2\end{array}$ & $\begin{array}{l}-11.0 \% \\
-16.6 \\
+0.8\end{array}$ \\
\hline
\end{tabular}

* Excluding areas newly defined as "urbanized" in 1970.

Source: U.S. Bureau of the Census, U.S. Census of Population: 1970, Number of Inhabitants, Final Report PC(1)A1, United States Summary (Washington, D.C., USGP0, 1971). 
During this period, urban sprawl appears to have influenced agricultural land values and productivity. For example, Schmid (1968) reports that raw unimproved land value is about nineteen times greater for residential uses than it was for agricultural or forest uses. The expectation by farmers to cash in on these apparent profits led Colighlin (1977) to coin the term "impermanence syndrome" to describe how farmers anticipate urbanization and the resulting change in social and economic conditions. Work by Berry (1978) and Plaut (1976) indicate that when farmland owners anticipate converting their land to urban uses, they begin disinvesting in agricultural inputs, and farmland production gradually declines until it ultimately idles. Berry, for example, notes that for each acre urbanized during the 1960s in the Middle Atlantic states, another acre of farmland became idle; such actions by farmers can be considered efficient in the sense that agricultural inputs to land in the path of urbanization are not wasted.

Oregon discovered itself not immune from the urbanization trends of the 1960s and early 1970s. During this period, Oregon's population grew at a rate roughly twice the national average and most of this growth was focused in the counties comprising the fertile willamette Valley, an area of about 5,000 square miles. While comprising on $y$ about 10 percent of the state's farmland, the Willamette Valley accounts for 40 percent of the state's agricultural productivity. Concerned about growth trends, then-Governor McCall commissioned Halprin \& Associates (1972) to report on the Valley's apparent urbanization trends. By relying on Willamette Basin Task Force (1969) 
projections, Halprin showed that, without intervention, the volume of urban iand in the Valley would increase by 75 percent, or about one quarter of a million acres, between 1966 and 2000; another 370,000 acres would be devoted to related uses such as garbage sites, airports, roads, parks, and water storage. Halprin estimated that roughly 1,500 square miles of the Valley's land area would be devoted to urban and related uses by the year 2000, as shown in Table 1.2.

Table 1.2

URBANIZATION IN THE WILLAMETTE VALLEY: $1966-2000$

\begin{tabular}{|c|c|c|c|c|c|}
\hline Category & 1966 & 1970 & 1980 & 1990 & 2000 \\
\hline $\begin{array}{l}\text { Population }\left(000^{\prime} s\right) \\
\text { Actuala } \\
\text { Projected } \\
\text { Land Uses } \\
\text { (000's of Acres)c } \\
\text { Cropland } \\
\text { Native Pasture } \\
\text { Woodland } \\
\text { Urban } \\
\text { Urban-Related } \\
\text { Other }\end{array}$ & $\begin{array}{r}1,456 \\
237 \\
5,101 \\
332 \\
583\end{array}$ & 1,496 & $\begin{array}{r}202 \\
5,054 \\
434 \\
280 \\
304\end{array}$ & 2,083 & $\begin{array}{r}1,421 \\
156 \\
4,983 \\
568 \\
370 \\
211\end{array}$ \\
\hline
\end{tabular}

a U.S. Bureau of the Census reports and Center for Population Research, Portland State University (for 1980). Notice the accuracy of projections for 1980.

b Oregon State Economic Task Force projections, May, 1972.

c Willamette Basin, Comprehensive Study, Willamette Bas in Task Force, Pacific Northwest River Basins Commission, 1969.

d Year 2000 figure given in "Urban-Rural Planning and Taxation", speech by Ken Omlid to Eugene Rotary Club, May, 1972. Year 1980 figure interpolated. Both figures taken out of "0ther" land use category.

Source: Halprin, Lawrence, The Willamette Valley: Choices for the Future, Willamette Valley Environmental Protection and Development Planning Council, State of Oregon, Salem, 1972. 
In 1969, the Legislature adopted Senate Bill 10, the state's first statewide planning effort. Although all jursidictions were required to prepare comprehensive plans, there was general agreement that Senate Bill 10 neither specified planning expectations nor enforced the planning process. For example, Jeffrey (1983) reports that in 1973 alone, almost 30,000 acres of Willamette Valley farmland was lost to urban development. Sullivan (1975) cläims that rural land remained loosely controlled through this period, resulting in largely unplanned residential growth outside of cities.

Dissatisfied with ineffective planning and concerned about urbanization trends, especially in the Willamette Valley, Governor McCall proposed a planning program which (1) contained urbanization, (2) protected open spaces, and (3) controlled land uses on a Valleywide basis under state guidelines. In 1973, the Legislature adopted Senate Bill 100 - the "Oregon Land Use Act" - which affected not only the Willamette Valley but the entire state. Senate Bill 100 created the Land Conservation and Development Commission ("LCDC"), a gubernatorially selected seven member panel, and its administative arm - the Department of Land Conservation and Development. The LCDC was notably made responsibie for: (1) creating, interpreting, and administering statewide planning goals - 19 of which were effective by 1976, (2) deciding whether local comprehensive plans complied with the goals, and (3) assuring broad citizen involvement in plan-making. Furuseth (1980, 1981), Gemache (1981), Gustafson, Daniels and Schirack (1982) and Nelson (1983a, 1983b) observe that Oregon's statewide planning program consists of two cornerstones: (1) rural 
1 and use restrictions and (2) urban growth boundaries ("UGBs"). Rural land use restrictions include (a) statutorily required, locally administered "exclusive farm use" (EFU) control of all land liberally defined as "farmland" and (b) extensive application of non-statutory forest and mixed farming-forestry zones which are in many ways tantamount to EFU restrictions. Gustafson, et al, note that minimum lot size (MLS) zoning is the most widely used method of preventing the conversion of rural land to nonfarm and nonforest uses. Urbanization is more specifically contained by UGBS, which distinguish between urbanizable and rural land. UGBs define the outer limits of urban services and are typicallij astablished to accommodate projected urbanization demands over a twenty year period. Though the LCDC does not consider any comprehensive plan to be complete until its urban containment policies include both rural land preservation and UGB elements, the National Agricuitural Lands Study (1981b) characterizes UGBS as Oregon's fundamental agricultural preservation planning tool. The nature of Oregon's statewide planning program can be traced to an extensive literature ident ifying various problems associated with urban sprawl including its costs, impact on certain public goods and amenities, and influence on speculative behavior. The next section wiil summarize the treatment of these issues in literature and show where Oregon's urban containment efforts are focused. 


\section{A. SOMF. IMPORTANT ROLES OF URBAN CONTAINNENT POLICIES}

The view that "urban spraw1" must somehow be coniained ignores the question of what it is. According to Kain (1966), it is usually impossible to determine whether planners understand sprawl to be a pattern of compact, contiguous development of large lots or a pattern of scattered, non-contiguous development of small lots, or both. The literature of Gottman (1961), Clawson (1962), Schmid (1968), and others, tends to view urban sprawi as a "leapfrogging" 1 and conversion process where urban development outflanks some farms while engulfing others. But, it is Harvey and Clark (1965) who define at least three distinct patterns of urban sprawl. First, sprawl may be very low density development of a large area, where single family homes are built on small acreages of about two to five acres, or more, thus consuming large amounts of land which some believe should be either developed at higher densities or banked for future urban needs. Second, sprawl may be more intensive development extending out from built-up areas along major highways, while space between these developed corridors remains underdeveloped. Third, sprawl may be characterized as a "leapfrogging" development pattern where relatively compact urbanization flanks or surrounds undeveloped iand. Lessinger (1958) indicates that this latter form of sprawl is really an efficient process of urbanization. As residential developmeni extends outward from the central city, some landowners keep their land vacant until such time as community level facilities, such as schools and shopping centers, are needed.

The nlanning literature indicates nearly uniform agreement that uncontrolled sprawl has undesirable costs and impacts. They tend to 
agree that urban containment programs should reduce the costs of sprawl, preserve open space benefits, and eliminate rural land speculation. The extent to which Oregon's urban containment policies are intended to achieve these outcomes is reviewed here.

1. Reducing the Costs of Sprawl

Einsweiler, et al. (1975), note that urban growth management systems are motivated by a desire to reduce the costs of extending public services and facilities to an expanding urban fringe. The Real Estate Research Corporation (1974a) suggests that urban sprawl causes (1) over-investment in public facilities and services because households demand those services over widely separate areas; (2) increasing average and marginal costs of providing services such as water and sewer, school buses, fire and police services, electrical distribution, road construction and maintenance and; underutilization of existing facilities and services because of shifting population. Thus, one of the functions of urban containment policies is to provide facilities and services to an expanding population in an efficient and cost-effective manner.

The effect of urban sprawl on the cost of delivering public services is far from clear, however. Kain contends that:

(views to the effect that sprawl is wasteful and inefficient, or is otherwise responsible for local fiscal problems, are) exceedingly difficult to document. Such allegations are usually based upon opinion, intuition, and appear to be strongly influenced by what the observer wishes to believe. Evidence of these supposedly higher costs is more qualitative than quantitative and the proponents of these views rely more heavily on rhetoric than on careful documentation to support their positions.(BGRS, 1974,p.4) 
The Bureau of Governmental Research and Service ("BGRS", 1974) quotes the Nationai Academy of Sciences' Subcommittee on Land Use in this same regard:

Although the supposed excessive development costs associated with the present conversion process have been described by many, hard and comparable data to support such a conclusion are scarce. ... Those who criticize 'sprawl' have not effectively responded to those who argue that: (a) the present pattern of development not only conforms to consumer desires but may be an effective way of holding land from premature development; (b) while initial development costs may be higher, subsequent strategic 'in fill' may in the end actually result in lower total costs than would have been possible with more planned or ordered development; (c) the present pattern of development provides more options with respect to the acquisition of cheaper land than would a more regulated and orderly one; and (d) most development costs are 'insensitive' to the form of development. (BGRS, p. 5)

While several case studies show that it is less costly to provide public services to cluster developments than to conventional developments, the National Academy of Sciences observes that: "Very few (of these studies) consider the impact of cluster developments on community or areawide development costs or operating costs related to alternative development patterns." Furthermore, Beaton, Johnson and Hibbard (1972) suggest that savings may merely result in higher urban land prices because (a) the total supply of buildable land available to meet demand may be constrained because of containment and (b) public savings - in terms of reduced property taxes, for example -will be capitalized into the land anyway.

Urban containment policies are also intended to reduce other costs of sprawl. In their influential publication of the early 1970s, The Costs of Sprawl, the Real Estate Research Corporation (1974a) calculates that sprawl wastes energy and increases air pollution. 
Their model high density community would utilize 44 percent less energy and result in 45 percent less air pollution than a model of a typical low density community, given equal populations.

In response to these claims, Altshuler (1979) notes that these costs are difficult to prove. For example, The Costs of Sprawl assumed 1600 square feet for low density homes but only 900 square feet for high density homes. This difference alone accounts for a substantial portion of the projected energy savings outcome. Other energy savings attributable to reduced vehicle travel were apparently due to a calculation error of roughly twenty-percent. He implores that residential energy use should be put into perspective: only one-fifth of a typical urban area's energy consumption is attributable to residential use.

He then notes that human exposure to air pollution in the high density model community portrayed in The Costs of Sprawl is roughly twice that of the typical low density community, even though per capita air pollution emissions are lower in the ligh density community. He implies that the cumulative effect of pollution in high density areas may be more detrimental to personal health than that in low density areas.

Others contend that sprawl is inevitable, and not merely a feature of the latter half of this century. Harrison (1974) notes that the rate of urban dispersion in the U.S. has remained notably constant since the late nineteenth century, and probably would have proceeded without such sprawl-inducing programs as highway construction, housing and tax policies. 
Reducing the costs of sprawl is not an apparently well-defined objective of Oregon's statewide land use planning program. For example, data describing the costs of sprawl are not presented in Halprin's (1972) study. In addition, the LCDC has never required that a community demonstrate savings attributable to one urban planning strategy over another, nor has it required capital improvement programs - a technique largely used to plan for and minimize the expense of extending urban services. Rather, preventing the pavingover of the Willamette Valley appears to be the primary underlying motivation of Oregon's statewide land use planning efforts. Preserving open spaces appears to be the fundamental motivation behind Oregon's entire statewide land use planning program according to Gemache (1981), Furuseth (1980, 1981), and Gustafson, Daniels and Schirak (1982).

\section{Preserving Open Spares and Related Public Goods and Amenities}

One distinct benefit commonly attributed to urban containment policies is that they provide open spaces near urban centers. The idea of preserving open spaces as a way of enhancing urban living dates roughly to the 13 th century, B.C, when:

The Lord said to Moses .... 'Command the people of Israel, that they give to the Levites ... cities to dwell in; and pasture lands round about the cities. The cities shall be theirs to dwell in, and their pasture lands shall be for their cattle and for their livestock and for all their beasts. The pasture lands of the cities ... shall reach from the wall of the city outward a thousand cubits all around. (Numbers 35: 1-4)

In the 16th century, Thomas More developed his utopian network of towns with limited size and open internal layout, distributed over the 
agricultural landscape. Toulan (1965) observes that many of the ideas and the works of 19th century England presumed that open spaces directly benefited urban conditions. For example, owen and later, Buckingham, emphasized the need for open spaces and greenbelts in and around urban areas. In America, Olmstead designed New York City's Central Park to "provide for the masses of the city a brief equivalent of a visit to the countryside". Thoreau and Marshall recommended vast reserves of natural open land on the outskirts of cities in both America and England.

0sborn (1946) credits Ebenezer Howard's Garden Cities of ToMorrow (1902) with uniting the complementary purposes of limiting urban sprawl through the use of open space preserves. Howard proposed to limit city population to 32,000 , of which 2,000 would actually reside in a permanent agricultural greenbelt surrounding the city. Howard's approach launched the "Garden City" movement which in turn influenced city planning throughout England and America. His ideas are largely responsible for London's Green Belt Act of 1938, and the founding of such towns as Greenbelt, Maryland; Greendale, Wisconsin; and Greenhills, Ohio during the 1930s.

Toulan notes that the open space movement has recently shifted away from utilizing open spaces as an urban planning tool to the preservation of open spaces outright. This new emphasis was the product of two general events. First, rapid suburbanization following World War II focused attention on the need for direct government intervention to preserve open spaces in and near metropolitan areas. Second, the desire to guide development away from open spaces, 
allowing for open spaces to meet recreational and natural resources needs, became articulated.

Plaut (1976) identifies the negative influences which urban development imposes on agricultural productivity. Along the urbanrural fringe the coliective political, social and economic activities of urban residents result in: (1) reduced hours of farm equipment operation to avoid disagreeable noises at odd hours; (2) reduced access of slow moving farm vehicles to major highways; (3) increased constraints on the use of certain fertilizers and pesticides near residents; (4) increased vandalism by neighbors, or crop and livestock losses due to neighbors' pets; (5) harrassment of farm animals and; (6) inhibited ability to expand farm operations as farmers compete for land also sought by non-farmers. These urban influences reduce agricultural productivity and the value of land for agricultural uses. Similar concerns are expressed by Libby (1974), Berry (1976, 1978) and Coughlin, et al. (1977).

Hanson (1976) notes that open spaces provide a range of public goods and amenities. Whether publicly owned or not, open spaces provide public goods such as air cleansing, groundwater storago: flood control and elimination of waste. Amenities include visual satisfaction, privacy, and opportunities for passive and active recreation. In addition, farmland may be considered a merit good because its value to the public may not be fully understood. For example, Gibson (1977) indicates that cropland may be undervalued in the marketplace for its value in making the public less vulnerable to future food shortages. 
Oregon's legislators recognized the benefits of open spaces when they adopted the "Agricultural Land Use Policy Act". This Act specifically intends to contain urbanization and preserve farmland and other open spaces when it declares that:

(1) Open land used for agricultural use is an efficient means of conserving natural resources that constitute an important physical, social, aesthetic and economic asset to all of the people of this state, whether living in rural, urban or metropolitan areas of the state.

(2) The preservation of a maximum amount of the limited supply of agricultural land is necessary to the conservation of the state's economic resources and the preservation of such land in large blosks is necessary in maintaining the agricultural economy of the state and for the assurance of adequate, healthful and nutritious food for the people of this state and nation.

(3) Expansion of urban development into rural areas is a matter of public concern because of the unnecessary increases in costs of community services, conflicts between farm and urban activities and the loss of open space and natural beauty around urban centers occurring as the result of such expansion. (ORS 215.243.)

Whether intended to provide greenbelts, contain urban sprawl, preserve agricultural land and enhance its productivity, or to preserve public goods, merit goods, or amenities, Oregon's statewide planning program appears committed to preserving rural land.

\section{Removing Speculative Use Value of Rural Land}

Clawson (1962) views land as a commodity subject to price fluctuations based upon its supply and demand characteristics at any given period in time. While noting that landowners typically expect to profit from land, Clawson observes that the prospect of profiting from conversion of land from one use to another, usually in the form of converting farmland into subdivisions, has somehow met with moralistic dissatisfaction in the public. Realizing profits from land 
use conversicr depends on a number of factors, many of which are beyond the control of the landowner. First, the location of land with respect to transportation and urban utilities is largely dependent upon actions of government. Second, uses of land are largely predetermined through zoning and building codes. Third, the actual market for land is a derived one, dependent upon the market for commercial, industrial, residential, and public uses. In this regard, there is much uncertainty about particular markets. The market for housing, for example, is often fragmented and variable over distance and time. Fourth, the market for land, especially large tracts, is usually thin and involves a few buyers negotiating with a few owners.

Clawson (1971) expects that land speculation will occur if it is withheld from the market for economic reasons by a rational, profit maximizing, landowner. If a landowner withholds land from the market, despite urbanization occurring adjacent to if not all-around his land, then what occurs is what some view to be the most costly and certainly the most often attacked form of urban spraw1: leapfrog development. Following this, Bahl (1968) theorizes that speculation will occur when the landowner decides to hold land an additional unit of time if the expected increase in market value of the land is great enough to compensate him for the additional cost incurred during that additional holding period. These costs include the property tax and the amount which would have been earned by investing an amount equivalent to the current market value of the land in the best alternative investment. The mere fact that the land sold for much more than it was purchased for is not evidence that a profit was made when considering its 
initial purchase price, the holding costs involved, and the discount rate applicable during the holding period.

The economic "ripening asset" theory suggests that land will be withheld from the market until a certain optimal date for development, or redevelopment, occurs. Shoup (1970) specifies that this moment depends upon (1) the discount rate applying to the real estate market, (2) the property tax rate, (3) the earnings of the land in any interim use, and (4) the way in which the highest and best use of the land is expected to change in the future. In this latter regard, Lessinger (1958) contends that land which has been leapfrogged over may become strategically located for uses such as schools and shopping centers which were not economically justifiable earlier.

Speculation requires the expectation that urban development will extend into rural areas within a foreseeable period of time. However, key court cases in Oregon - basing their decisions on statutes and LCDC policies - have all but ruled rural land speculation illegal in Oregon. In one case, the courts denied a rural residential subdivision by noting that nonfarm-nonforest related housing must locate in cities (Still v. Marion County, 42 Or App 115). In another case, the courts declared that the cumulative effect of small parcelizations is the frustration of rural land preservation efforts and a minor partitioning (short plat) was disallowed (Jurgenson v. Union County, 42 Or App 505; see also Rutherford v. Armstrong, 31 or App 1319). In yet another case, the courts allowed a rural subdivision only after a local government demonstrated that agricultural productivity would increase as a result (36 Or App 699). 
B. URBAN CONTAINMENT PROGRAMS INFLUENCING OREGON'S EFFORTS

Importan't elements of Oregon's statewide urban containment program can be traced to those of Great Britain, other American cities, and the state's capital city - Salem. These efforts and their applicability to Oregon's statewide program will be reviewed here.

\section{The British Example}

As noted earlier, Britain has long been interested in containing urbanization and preserving the countryside - especially since initiation of the "Garden City" movement earlier this century. While some important "Garden City" legislation was adopted prior to World War II, Haii, Thomas, Gracey and Drewett (1973) report that Britain's major urban containment efforts began when Parliament passed the "Town and Country Planning Act of 1947". While complex and modified several times since its implementation in 1948, four features of the Act are relevant here. First, each county and borough was responsible for preparing plans acceptable to a nationa? ministry. Second, urbanizable areas were delineated by "stoplines", beyond which urban services and growth could not expand without ministerial "permission" - which was made exceedingly difficult. Third, because these policies removed speculative use value of rural land near urban areas, landowners were compensated for their negotiated losses from a 300 million pound-sterling fund. This particular feature effectively created "greenbelts" around major urban areas, and their permanency is largely ensured because compensation provides strong political rationale for prohibiting conversion to urban uses. Fourth, a series 
of "satellite" towns were targeted to accommodate regional urban growth. Satellite towns consisted of both existing and new towns and were physically designed to absorb "spillover" development pressure from the major central cities. Satellite towns were largely financed by the "New Towns Act" and the "Town Development Act".

\section{American Examples}

Einsweiler, et al. (1975), report that in recent years, several urban areas of medium to large size have employed urban containment programs. These programs are typically intended to accommodate projected five to twenty year demands for urban land with in delineated regions. They usually involve restricting the expansion of urban facilities beyond an "urban services limit". Urban containment programs also typically employ capital improvement programming, construction quotas, planned development incentives, and a variety of other policies intended to assure long term success of the program. These programs also include a variety of extra-territorial controls over land in order to prevent the frustration of urban containment efforts within a region. Many states allow cities review authority over land use decisions (typically subsivision decisions) several miles beyond sity linits. Other cities employ restrictive extraterritorial urban service extension and annexation policies. In some states, cities and counties enter into joint management agreements covering the urban-rural fringe, in which joint agreement is needed to approve zoning and development requests. Notable jurisdictions having urban containment programs include Dade County (Miami) Florida; 
Lexington-Fayette County, Kentucky; Brooklyn Park (a township northwest of Minneapolis), Minnesota; Sacramento, California; Ramapo Township, New York; Montgomery and Prince George's County, Maryland; Petaluma, California; and Salem, Oregon.

\section{The Salem Example}

Several years prior to implementation of Oregon's statewide land use planning program, the Salem urban area began planning for and adopted a comprehensive urban containment program. The program required the cooperation of several jurisdictions and resulted in (1) a delineated urban growth boundary (UGB) around an urban area straddling the Willamette River in two counties, (2) downzoning vast amounts of rural land beyond the UGB, and (3) several jointjurisdiction management agreements covering virtually all major aspects of urban expansion and rural development.

The concept of a UGB around Salem began in 1970 with a resolution by the Governmental Coordinating Committee of the Mid-Willamette Valley Council of Governments (MWVCOG), an organization comprised of Marion and Polk Counties and their respective cities and special service districts, to the counties and the City of Salem. The resolution stated that:

Development work on comprehensive plans now underway for Marion and Polk Counties and the City of Salem (should) include delineation of an optimum urban growth boundary for the central city of Salem as a specific community directive. Such a boundary should reflect multiple considerations involving land use, sanitary drainage bas in limits, transportation patterns, economic patterns, and soil types. (Minutes, 8-11-70.) 
In August 1973, a statement of intent was signed by these three jurisdictions to develop plans and policies consistent with a UGB concept. In addition, special districts and agencies such as the Salem School District Board and the Marion-Polk County Local Government Boundary Commission also adopted policies supporting the UGB concept. By the end of 1974, Marion County and the City of Salem had adopted specific limits of a UGB, and by the end of 1975 the downzoning of land situated beyond the UGB was substantially completed.

The motivations behind preparing the UGB included the twin objectives to contain urban "sprawl" and preserve agricultural land:

Much land in our urban area is very inefficientiy used. About $25 \%$ of the land of the city lies vacant. Lands on the outskirts of a developing area are usually less expensive than those close to the city and thus they may appear preferable for development. But this process of "leap-frogging" over vacant land in the urban area to build on land further out results in what is commonly called "urban sprawl".

The problems "sprawl" poses to this area are particularly significant because of the importance of agriculture to the local economy. Choice farmland is lost when urban developers outbid farmers for the land. Agricultural interests have expressed deep concern about the way prime farmlands are being permanently removed from agricultural production. (An Urban Growth Policy for the Salem, Oregon, Area, MWVCOG, August, 1973.)

This same policy document also expressed a concern about how Salem would grow, especially in light of projected rapid growth:

Salem began as a community in 1850, and by 1870 there were on!y 1,300 people. In the first hundred years the city grew to 43,000 people and 10 square miles. In 1970 the city has 26 square miles with 69,000 people and about 100,000 in the Salem urban area. Salem will continue to grow but we have some choices in how it will grow. It's projected in the Salem Area Comprehensive Plan by 1990 at least 160,000 people will be residing within the Salem urban area. (Emphas is in original.) 
Thus, given its projected growth rate and local sentiment against allowing the city to expand into rural areas, the Salem UaB was designed and implemented. The UGB generally followed drainage basins and property lines within which substantial urbanization was intended. It also included other areas intended to remain largely open and deveioped such as (1) a large open area in the southeast sector owned by state and local governments and some private interests because their facilities - state prison facilities, airport, naval reserve center, and a bible college - used some urban services and (2) a large area of Willamette siver floodplain land because it included the city's sewerage treatmant facilities. The UGB extended across the Willamette River into Polk County to include West Salem, a popular suburban district connected by a bridge system to downtown Salem. Then, in order to preserve the agricultural areas north and east of Salem and still meet projected urban land use demands through the balance of the century, the UGB was drawn to intentionally shift development pressure into South Salem, an extensive area of rolling hills. All other Willamette River bottom land and much of the rural land situated outside of the UGB and north of the Santiam Highway and in Polk County was zoned EFU.

Salem's historic urbanization pattern is shown on Plate 1.1 . Plate 1.2 iliustrates the location of Salem's urban area (which is delineated by its UGB) in relation to the state of Oregon and the midWillamette Valley. 


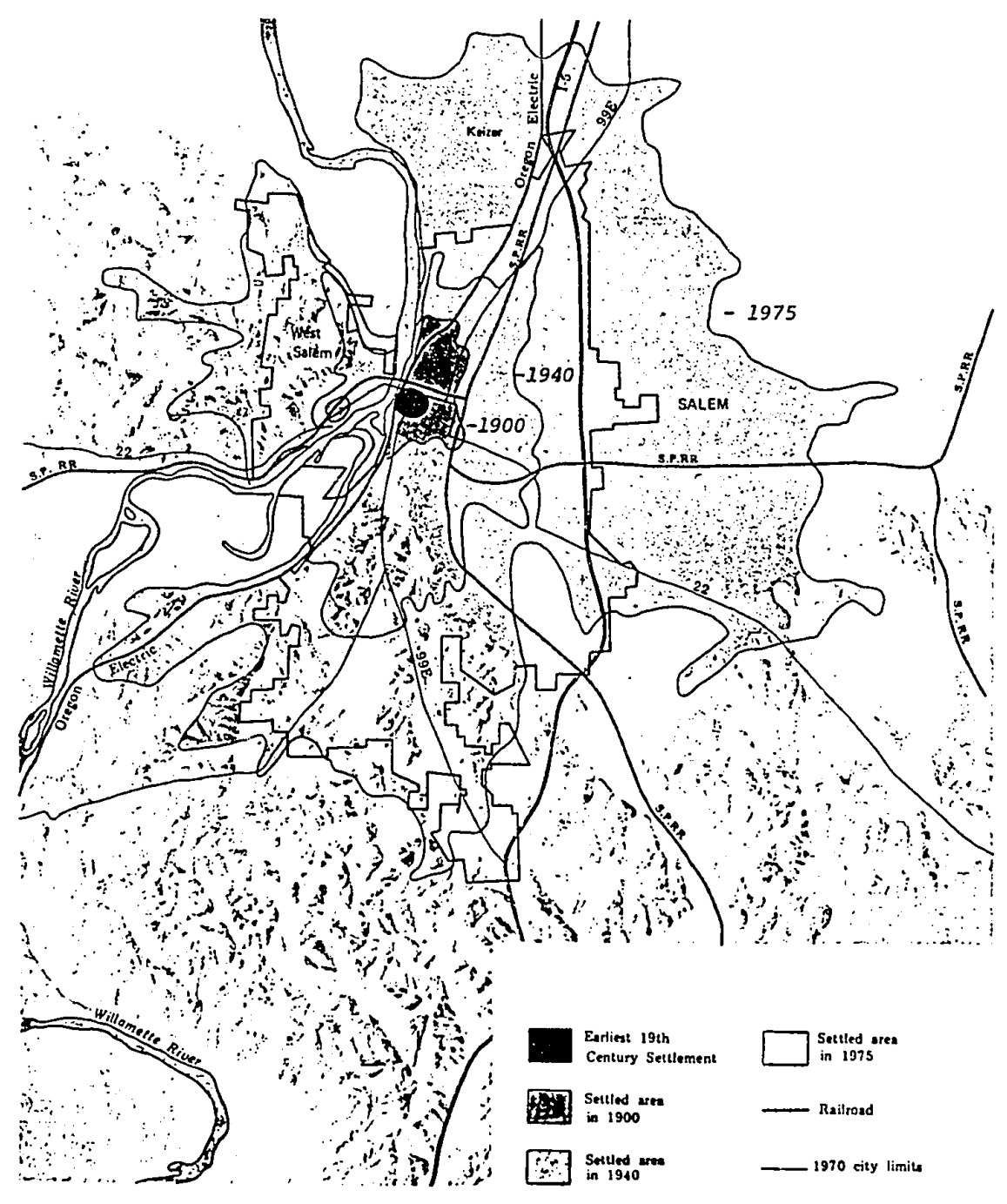

PLATE 1.1 Spatial development of Salem, Oregon, 1900 to 1975. (From University of Oregon, Atlas of Oregon, 1976.) 


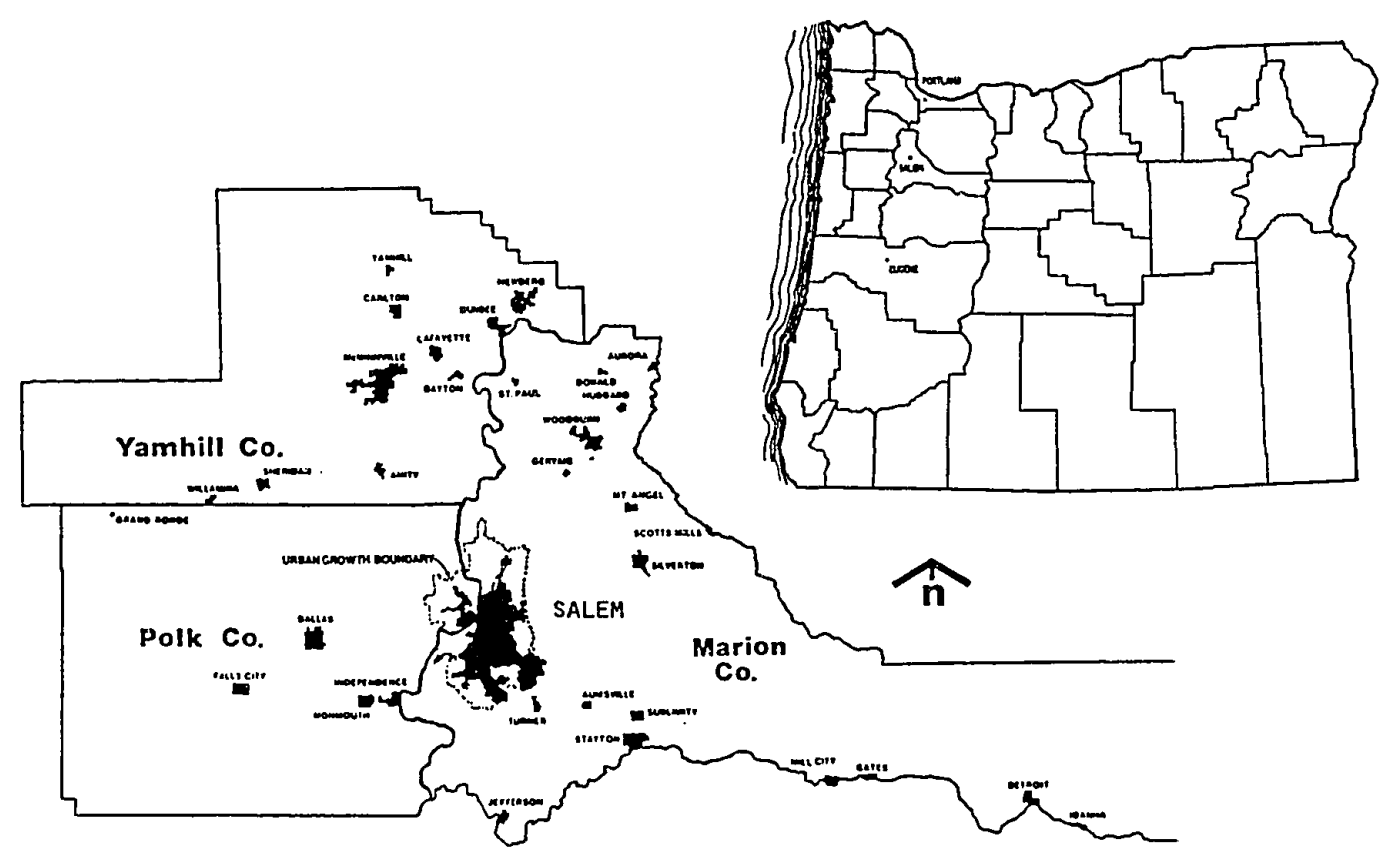

PLATE 1.2 Location of Salem and its urban area in Oregon (above right) and within the Mid-lillamette Valley (lower left). 
4. Oregon's Statewide Urban Containment Efforts

Largely following these various leads, Oregon's statewide urban containment program became effective January 1, 1975. Oregon's program requires all cities and urban areas to "provide for the orderly and efficient transition from rural to urban uses". This objective is accomplished by separating "urbanizable" land from rural land. "Urbanizable" land is that which may be converted to urban uses in the future but which is currently beyond the reach of urban services. The process of identifying urbanizable land is the most critically reviewed process of any city or county plan. In general, the process entails: (1) accepting an LCOC approved population projection, (2) detailed analyses of the landscape in order to determine land which is subject to development constraints such as flooding, severe slopes, weak soils, etc., (3) projecting the twenty or so year demand for urban land, (4) allocating land to meet the demand, (5) designing a capital improvement program to extend key facilities and services into urbanizable land, and (6) adopting a site-specific UGB which is acceptable to all affected jurisdictions, such as nearby cities, counties, special service districts, and the ICDC.

Because Oregon's land use planning program is structured to be a series of state-coordinated local plans, the LCDC is vested with the power to determine whether local plans comply with the statewide flanning goals. The LCDC has apparently held high standards for local governments to follow in preparing acceptable plans: by late 1983 nearly 90 percent of all plans submitted to the LCDC for review for 
the first time have been rejected. The most common reasons for rejection include: (1) population projections which appear too high or are not based upon official agency projections, (2) housing densities and overall urban land use intensities which are too low, and therefore require more rural land to be urbanized than considered necessary by the LCDC, and (3) allocating more urbanizable land than is needed within twenty years. In this latter regard, the LCDC usually denies plans which attempt to avoid creating excessive demand - in other words, the LCOC prefers plans which anticipate total infill to plans which attempt to minimize private monopolistic behavior. 


\section{CHAPTER 2}

\section{A Unified Theory of Urban Contairment Influences on Urban-Rural Land Values}

The performance of urban containment programs can be evaluated by comparing their effects on the urban-rural land market to theoretical expectations. Unfortunately, a theory of urban containment effects on land values does not exist except as disjointed contributions from the economic, geographic and planning disciplines. A unified theory incorporating relevant features of these independent contributions is constructed of three components. First, if uriban containment policies intend to focus growth within UGBs, then one should expect an excessive demand for urban land to result and consequently effect segmentation of the urban-rural land market. Second, when an urban containment program uses conservancy zoning for the purpose of creating greenbelts surrounding urban areas, then it should effect the removal of the speculative use value component of rural iand and reveal the underlying agricultural use land value gradient proximate to a UGB. Third, proximity to these greenbelts should be internalized by the urban land market as an amenity. These components are reviewed and combined into a unified theory. 
A. SEGMENTING THE URBAN-RURAL FRINGE LAND MARKET

Market segmentation can be affected by socioeconomic discrimination between areas, which Becker (1957) and Rosser (1978) identify as "ghetto" segmentation. Clawson and Perloff (1975) note that zoning is commonly employed to create and/or reinforce such socioeconomic segmentation. Ohls, Weisberg and White (1974) suggest that "fiscal" zoning can increase aggregate municipai property vaíues if it segments the market by socioeconomic strata. Lafferty and Frech (1978) suggest that if an urban development program concentrates development within a municipality, then property values rise throughout it and the regional land market becomes segmented into urban and rural submarkets. In all of these examples, a gap in the locus of land values is expected along the boundary between districts created by socioeconomic discrimination, zoning, or urban development policies.

Whitelaw (1980) presents a simplified version of how an urban containment program may segment the land market. In the absence of a program, any notable differences between land prices on adjoining parcels should be explained by differences in the determinants of land values such as location, size, socioeconomic factors, negative externalities and amenities. However, if a program uses a UGB and other containment policies to differentiate between urban and rural land, it does so by creating a gan in the otherwise continuous locus of urban and rural land values at the UGB. In Fig. 2.1, $R^{m}$ represents the unrestricted locus of land rents along the urban-rural fringe and curve RG represents the locus of land values resulting from the same 


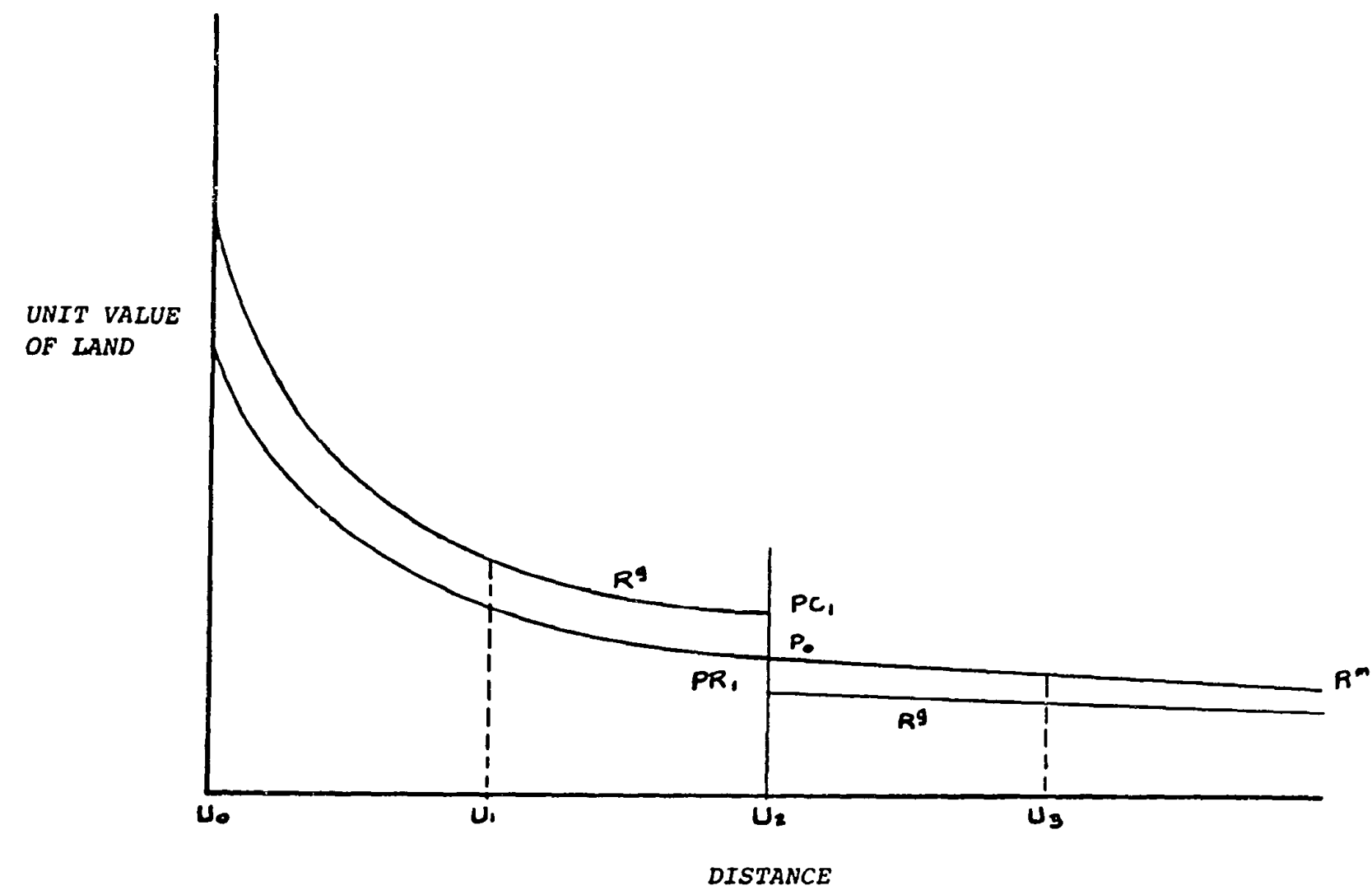

FIGURE 2.1: EFFECTING SEGMENTATION OF THE URBAN-RURAL LAND MARKET.

When an Urban Containment Program differentiates between urban and rural land uses at an Urban Growth Boundary, $u_{2}$, it does so by creating a gap in the locus of urban and rural land values at $u_{2}$ and the land value gradient shifts from $R^{m}$ to $R^{g}$. 
forces affecting $R^{m}$, plus the increment which results when urban land uses are denied locations beyond the UGB at $u_{2}$. Under an urban containment program, the value of 1 and at $\mathrm{u}_{3}$ is at $\mathrm{Rg}_{3} ; \quad$ land denied of urban development prospects is thus less valuable under urban containment programs than it would have been otherwise. Likewise, the value of land at $u_{1}$ is higher than it would have been otherwise because an excessive demand for urbanizable land will have been effected. Thus, an urban containment is expected to effect a gap in the locus of land values at $u_{2}$ in the manner illustrated in fig. 2.1. If a gap is not detected, then it may be concluded that (a) $R^{g}$ and $R^{m}$ are the same, (b) the program has no apparent effect on land values, and thus $(c)$ the regional land market has not been segmented into urban and rural components. In a model of land value determinants which allows binary differentiation between urbanizable (1) and rural (0) land, a significant and positive coefficient on that determinant is expected. Two studies employ such models to evaluate specific urban containment programs, but each offer mixed results. These studies will be summarized below.

Brooklyn Park, Minnesota, adopted its urban containment program in 1963, and enjoys the reputation as being among the pioneers of urban growth management. Gleeson (1979) studied its effect on urban and rural land values based on sales of 129 and 73 principally vacant land parcels in 1972 and 197t, respectively. He selected these time periods because they fell conveniently several years after program impiementation. He found that a segmentation binary attribute, differeritiating between large (15+) acreage parcels located inside or 
beyond the Brooklyn Park urban services limit, accounted for more than two-thirds of the difference in mean value between the urban and rural components, after accounting for other influences on price variation. His findings did not hold for smaller parcels. He surmised that larger parcels provide investors and developers with greater holding and interim use flexibilites.

Salem, Oregon, has employed an urban containment program since only 1975, but it is among the most celebrated in America. The program was rited by Oregon's Land Conservation and Development Commission as the example for all other urban areas of the state to emulate. Largely as a result of this directive, Oregon's statewide planning program has achieved a considerable reputation among planning analysts (see, e.g., Furuseth, 1980, 1981; National Agricultural Lands Study, 1981; Urban Land Institute, 1975; Gustafson, et a1., 1982; Jeffrey, 1983) and the planning profession (American Planning Association, 1982). Beaton, et al. (1977) studied the effect of Salem's program on sales of 105 vacant urban residential and rural 1 and exceeding one acre occurring in 1976. They did not find a significant coefficient on their binary segmentation attribute. They suggested that, because an ample supply of urbanizable land apparently exists in Salem, an excessive demand for urban land should not be detected until after a period of several years. They also suggested that short term urban service extension policies should be the major, if not the sole, policy influence on urban land values. 
B. REMOVING SPECULATIVE USE VALUE OF RURAL LAND

Boal (1970) theorizes the role which urban containment programs assume in removing speculative use value of rural land. Boal's theory is actually an extension of Sinclair's (1967) agricultural use land value, which itself is an extension of Von Thuenen's (1826) classical land rent theory. The first part of this section reviews (a) Von Thuenen's salient contributions to land rent theory, (b) contemporary urban land value theory, especially as it relates to the urban-rural fringe, and (c) Sinclair's theory. The second part of this section discusses Boal's application of Sinclair's theory to the evaluation of urban containment programs.

\section{Land Value Theory}

Von Thuenen theorizes that agricultural use land value increases as a function of market proximity and is influenced by commodity characteristics. In its simplest form, his theory described the pattern of nineteenth century German agricultural land uses as a system of six concentric zones around urban development. Land in the innermost zone commanded the highest rent. In order to outbid competing users, occupants of this zone had to produce the most valuable commodities of the time, such as vegetables and milk products, because these commodities enjoyed high yields per acre and were perishable under the transportation and storage conditions prevalent for the times, The second zone also commanded high rents, and occupants here were typically devoted to firewood and timber production because these goods could be produced in high volumes and 
also enjoyed high rents. However, because of the weight and bulk characteristics of these goods, transportation costs were also high and the second zone consequently did not extend far from the market. The third zone was occupied principally by rye, a valuable staple during Von Thuenen's time. The fourth and fifth zones were occupied by declining proportions of rye with pasture and fallow crops. Only land extensive livestock grazing occupied the outermost zone.

Alonso (1960, 1964, 1972) succinctly describes the relationship of 1 and value to market proximity and commodity characteristics within Von Thuenen's scheme, and then extends Von Thuenen's concept to describe the urban-rural land market. For example, Fig. 2.2 assumes that if wheat production yields $\$ 100$ per acre at the market and production costs are $\$ 50$ per acre, then a farmer growing wheat at the market would make a profit of $\$ 50$ per acre. At greater distances from the market, transportation costs of $\$ 5$ per mile per acre, for example, reduces profit to $\$ 25$ at five miles and to zero at ten miles. If pea production enjoys a market price of $\$ 150$ per acre, but production costs are $\$ 75$ per acre and transport costs are $\$ 10$ per mile per acre, then Fig. 2.2 shows the pea farmer's profit to be $\$ 75$ per acre at the market and zero at 7.5 miles.

The nature of the competition for space and location between these commodities simplifies Von Thuenen's theory of agricultural use land value. If farmers are merely tenants on the 1 and, then the relationship between farmer and landowner can be viewed as separate and profits realized by the farmer will be shared with the landowner. The landowner will naturally seek the highest return to his land and 
will allow only the highest paying farmer to rent his 1 and. As farmers bid against each other for more profitable locations until farmers' profits are everywhere the same, then what has been considered profit may now be considered rent; hence Von Thuenen's economic rent concept. Fig. 2.2 shows that, when landowners seek the highest rent, farmers will tend to produce peas at distances closer to the market than five miles and wheat at distances beyond five miles. At five miles, farmers are indifferent to the production of peas or wheat because the rent from each crop will be the same. Now consider that the wheat farmer has alternative bid-rent functions for land when market prices for wheat are higher and lower than the level indicated in Fig. 2.2, along each of which his profits are everywhere the same. Fig. 2.3 shows these alternative bid-rent functions, $R^{a}, R^{b}$ and $R^{c}$, superimprosed upon the actual market value of land, $R^{m}$. The user of land will select that location (L) where land rent $(R)$ is the lowest, which is the tangent of $R^{m}$ with $R^{b}$; profits will be maximized at this point because the user achieves equilibrium between location and rent. The market value of land is thus comprised of all competing users' selection of equilibrium quantities of location and rent. Thus, in Fig. 2.4, the distribution of land uses on the landscape is generalized as a pattern of concentric zones extending from the market center, where location is dictated by the progressively steeper bidrent curves of the central business, residential and agricultural users. The rent demanded at any location for a unit of land is that which a given user is required to pay in order to outbid all other potential users for that location. 


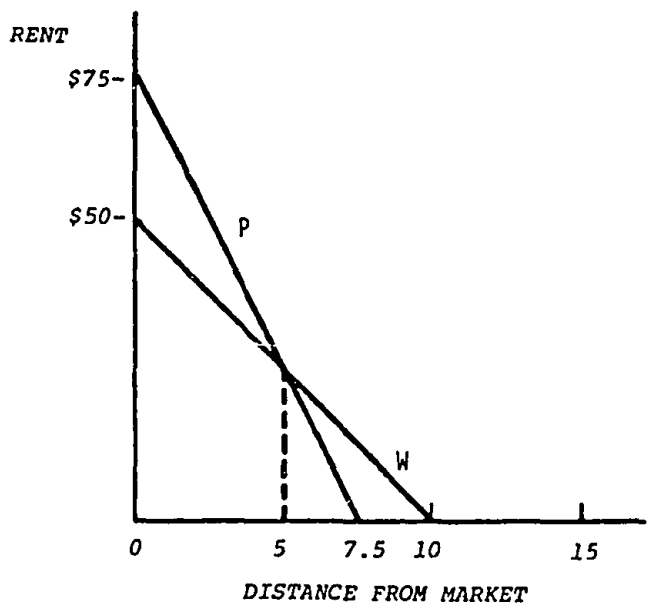

Fig. 2.2 The competition for location between Peas $(P)$ and wheat $(W)$. (From Alonso, 1972.)

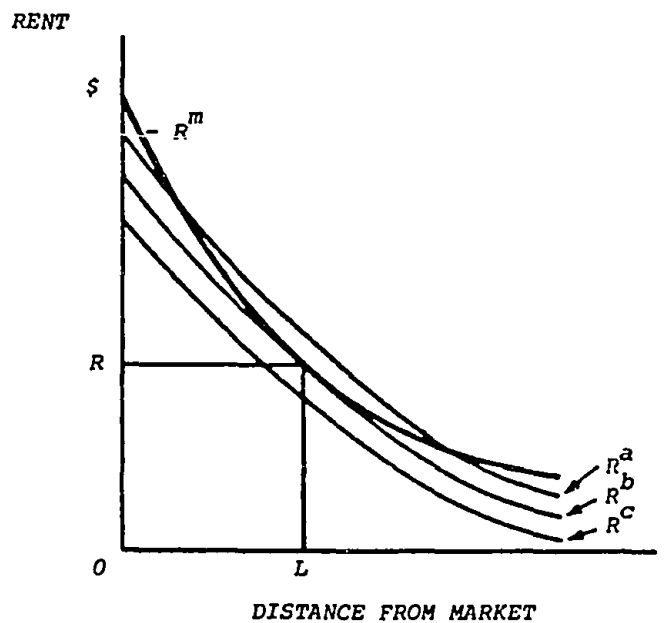

Fig. 2.3 A user of land with alternative bid-rent functions will select those quantities of location and rent where the market value of 1 and is tangent to the lowest possible bid-rent curve. (From Alonso, 1972.) 


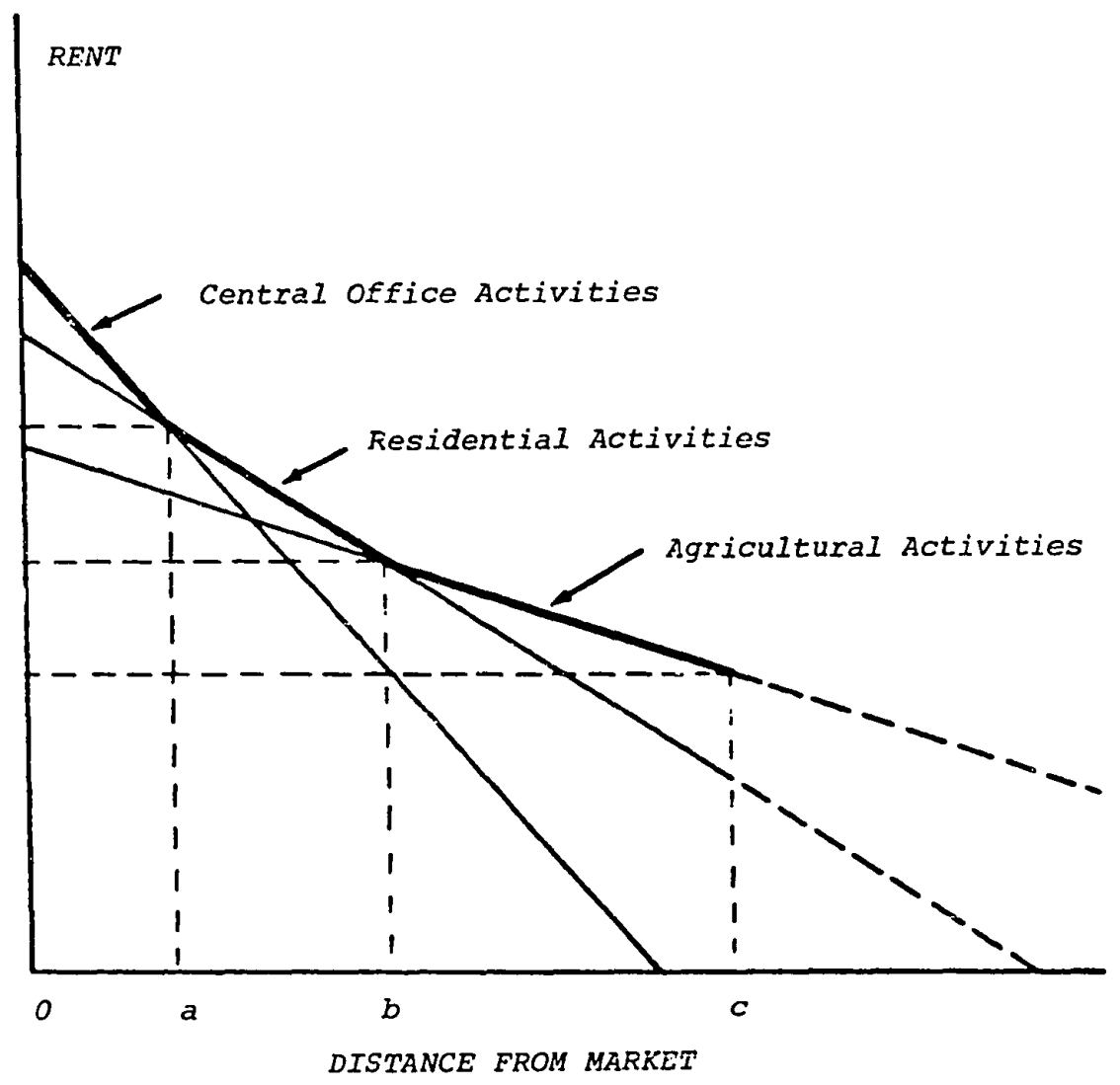

Fig. 2.4 Activities organize themselves on the urban landscape into a pattern where those with steeper rent functions than competing uses command central locations. 
Muth (1961) notes that changing population, technology, income, and other factors may effect urban spatial expansion into rural areas over time. Assuming residential and agricultural production and demand functions which decline with distance from the market center in a manner shown in Fig. 2.4, residential users outbid agricultural users to the left of $b$ while agricultural users outbid residential users to the right of $b$. The urban-rural boundary can be considered $b$, where users of land are indifferent to converting their land from agricultural to residential uses. Figure 2.5(a) shows that the demand and supply characteristics establish the equilibrium price of residential land users, $R_{1}$ (the equilibrium price of agricultural land users, $R_{2}$, is implied). If factor prices such as transportation costs and household wages are known for both residential and agricultural users, then Fig. 2.5(b) shows that the urban-rural boundary, b, can be drawn as the intersection of the rent functions of both users. In Fig. 2.5(a), if $P_{1}$ rises, this means that residential users' utility of land increases and they will be willing to pay higher rents. This change in residential users' taste for land may result in increasing their demand function to $D_{1}{ }^{\prime}$, and supply may also increase to $S_{1}{ }^{\prime}$ if residential land users outbid agricultural land users just beyond the boundary, $b$. This causes $R_{1}$ to shift to $R_{1}^{\prime}$ in Fig. 2.5(b), and the urban-rural boundary consequently extends outward to b'. Despite these conversion dynamics, however, Von Thuenen, Alonso, Muth, and others, asstime that the form of the agricultural use land value gradient will retain the feature of declining at a declining rate with respect to distance from the market. 


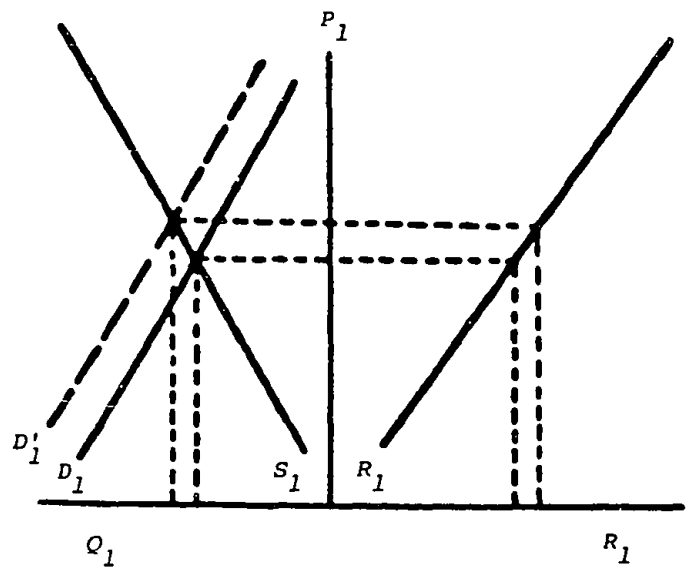

(a)

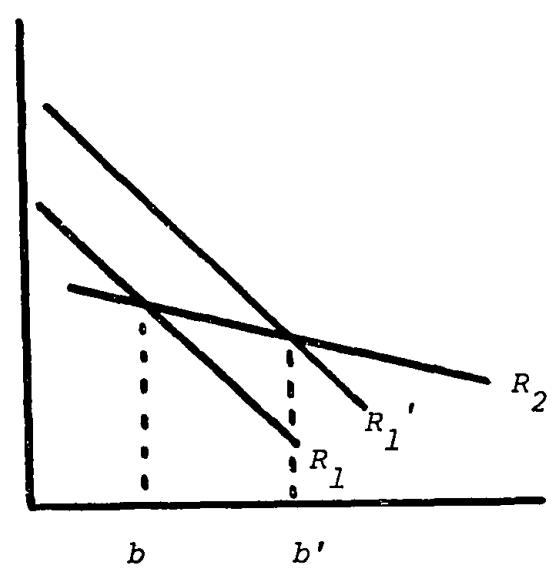

(b)

Fig. 2.5 The effect of changing tastes for residential land, $R_{1}$, on the location of the boundary between residential and agricultural activities $\left(R_{2}\right)$. (From Muth, 196I.) 
Sinclair observes that in twentieth century industrialized countries, where transportation has been vastly improved and perishable commodities can be hauled great distances and stored for long periods of time, the advantage of market proximity - so important during Von Thuenen's time - has been substantially diminished. Furthermore, the nature of agricultural production in industrialized countries has become more sophisticated; modern agricultural organization favors large-scale production and mass transportation of goods, which further diminish the advantages of market proximity. In fact, because modern agricultural operators enjoy national and world markets, proximity to transport routes and shipping points are likely more important location criteria than local market proximity.

Sinclair suggests two additional factors which affect the productivity of agricultural land proximate to the market. First, where urban and agricultural land users are juxtaposed, urban externalities will tend to inhibit agricultural productivity by trespassing and by imposing nuisance abatement to control dust, fertilizers, hours of operation, road use, noise, pesticides, irrigation, and so forth. Second, within the urban-rural fringe, undeveloped land is subject to the speculation that it will be converted to urban uses in a matter of time. The degree of this anticipation varies with respect to urban development proximity and the perceived rapidity of urbanization. Sinclair observes that the greater the likelihood of conversion, the less likely a farmer will find it practical to invest highly into agricultural inputs. The combination of urban externalities and speculation results in 
agricultural productivity increasing with declining proximity to urbanization until, at some point beyond urban development, the production-inhibiting influences are negligible: a phenomenon antithetical to Von Thuenen. Sinclair suggests that the innermost zone of agricultural production will be devoted to idled and developing land. The second zone will be devoted to idled land and land which is in temporary uses such as grazing. In both the first and second zones, little agricultural investment and maintenance cost is required to hold the land. The third zone will be one of transitory field crops and grazing, where nominal agricultural investments are observed. The fourth zone will be devoted to dairying and field crops while the fifth zone consists of specialized feed-grain livestock.

While some have disputed aspects of Sinclair's theory (Peet and Horvath, 1967), several observations and empirical efforts have supported his agricultural use intensity expectations. For example, Burgess (1925, 1929) described Chicago's land use pattern as one of concentric zones where the fifth through seventh zones were comprised of increasing agricultural intensity and declining urbanization pressure. Goitman (1961) reported vast amounts of agricuituraily underutilized land proximate to urban development within "megalopolis". Mattingly (1972) renorted declining agricultural land use intensity and an increasing incidence of "part-time" farming with increasing proximity to urban development in the Rockford, Illinois, area. Berry, et al. (1976) and Berry (1978) reported a survey of middle Atlantic states farmers which found that farmers tend to undergo a process of agricultural disinvestment in anticipation of 
urban conversion. Based on their review of literature and some empirical work, Coughlin, et al. (1977) coined the term "impermanence syndrome" to describe the situation where farmers anticipating urbanization and the resulting change in social and economic conditions, become disinterested in maintaining productivity levels.

Based on his pattern of agricultural uses proximate to urban development, Sinclair traces out the underlying value of $l$ and for agricultural uses as essentially a convex quadratic function with respect to distance from urban areas, shown as $R^{g}{ }_{1}$ in $F i g .2 .6$. However, because the unrestricted market value of land is observed at $\mathrm{R}^{\mathrm{m}}$, consistent with Alonso (1960, 1964), Mills (1969), and Muth (1961, 1969), Sinclair acknowledges that his peculiar agricultural use land value gradient will be obscured. His theory allows for a convenient definition of speculative use value of land. If the ratio of agricultural use land value to market value increases continuously with distance from urbanization unti? the ratio becomes unity, beyond which agricultural use land value declines, then the difference between agricultural use $l$ and value and market value at any point prior to unity must be speculative use land value.

\section{The Use of Urban Containment Programs to Reveal Sinclair's} Agricultural Use Land Value Gradient

Over most of this century, Britain's "garden city" movement has largely championed Howard's (1902) concepts for containing urbanization within greenbelts. In 1948, Britain's "Town and Country Act" required all urban areas to prepare plans consistent with it 


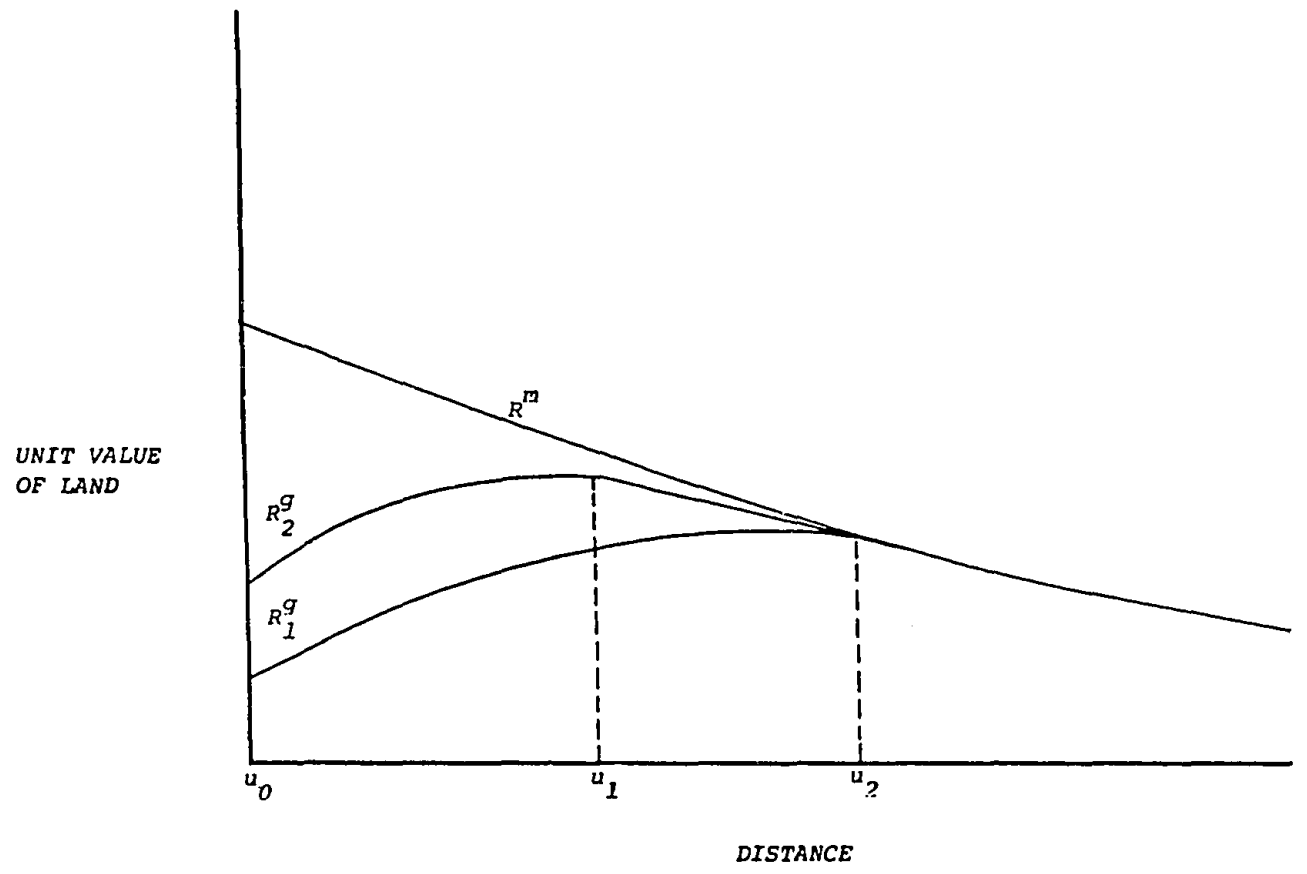

Figure 2.6 The market value, $R^{m}$, and agricultural use value, $R^{g}$, of land proximate to urban development at $u_{0}$. 
(see, e.g., Hall, et al., 1973). While complex and subsequently modified several times, two of the Act's features are relevant here. First, urbanizable areas were intended to be confined within "stoplines", beyond which urban services and low density urban sprawl was made exceedingiy difficult. Second, because the Act intendeu to remove speculative use 1 and value of rurai land, and convert rural land into a system of greenbeits surrounding urban areas, a three hundred million pound sterling fund was set-aside to pay for rural landowners' negotiated speculative use land value losses.

Einsweiler, et al. (1975a, 1975b) and Carter, et al. (1974), suggest that urban containment programs similar to Britain's are becoming an increasingly popular and steadily accepted regional planning strategy in America. These efforts typically consist of two fundamental features: the containment of urbanization within urban growth boundaries (iGbs) and the preservation of rural land generally for greenbelt (Isberg, 1973) or urban land banking purposes (Fishman \& Gross, 1972). Jurisdictions employing UGBS typically intend to contain urbanization within UGBS for a five to twenty year period and include a variety of specialized urban development controls including annexation policies (Freilich, 1975), planned unit development incentives (Eurcheî, 1972, 1973), capitai facilities programming (4irst \& Hirst, 1975), phased zoning (Urbanczyk, 1974), and so forth. Rural land is typically subjected to conservancy zoning (Rosser, 1978; Toulan, 1965), minimum lot size and use controls (Gustafson, et al., 1982), or outright purchase of development rights (Costonis, 1974). While some urban containment programs merely intend to slow the 
urbanization process into rural areas (Gleeson, 1979), others intend to preserve rural land soley for greenbelt uses (Gustafson, et al.; Furusețh, i980, i9̇8i).

If Sinclair's peculiar agricultural use land value gradient were ever to manifest itself, Boal suggests that it should do so as a result of urban containment programs. Following Sinclair, Boal notes that the market value of rural land is composed of speculative and agricultural use components. Within the urban-rural fringe land market, the speculative use land value component occupies the area between lines $R^{m_{R}}{ }_{1}$ in $F i g . ~ 2.6$, and exists at any point where the ratio of agricultural use land value to market value is less than unity. If an urban containment program separates urban from rural land by imposing a UGB at $u_{0}$, then it should effect removal of the speculative use land value component beyond the UGB and thereby reveal Sinclair's underlying agricultural use land value gradient at $\mathrm{R}{ }_{1}$. If the program is perceived by farmers to provide them with long term stability, then the program should also result in greater investments into and productivity of farmland, and the agricultural use land value gradient should shift upward to $\mathrm{R}_{2}{ }_{2}$. However, because urban externalities spill over the UGB and into agricultural land, Sinclair's peculiar land value gradient should remain evident. Both Boal and Rosser suggest that the success of an urban containment or greenbelt program may be evidenced by Sinclair's gradient. This researcher has not found empirical suppori for Sinclair's gradient; nor has he found any empirical effort to apply Sinclair's theory to the study of urban containment programs. 
C. GREENBELT PROXIMITY AS AN AMENITY IN THE URBAN LAND MARKET

In addition to offering a variety of public goods, open spaces may provide amenities to urban land proximate to it. If an entire urban area benefits from the existence of greenbelts, then the greenbelts can be considered to provide a pure public goud. In the other hand, if properties proximate to greerbelts enjoy exclusive consumption of certain goods such as views, privacy, and recreation, then greenbelt proximity may be considered a quasi-public good or amenity. In this regard, several empirical works report that the urban land market assigns an amenity premium to proximity to seyera? forms of publicly owned open spaces including water bodies and beaches (Li \& Brown, 1980; Diamond, 1980; Brookshire, et al., 1980; and Brown \& Pollakowski, 1977), large urban parks (Blomquist \& Worley, 1981; Hammer, et a1., 1971; Coughlin \& Kawashima, 1973; and Weicher \& Zerbst, 1973), and greenbelts (Correll, et al., 1978). The models employed in these studies typically viewed the commodity "housing" as representing a bundle of goods consisting of location, space and structure, and amenity attributes. By holding location, space and structure attributes constant, price differentials were attributed to amenities representing open space proximity. In all of these examples, the amenity value may be partly attributable to public ownership of the open spaces.

When the greenbelt is privately owned, the amount of amenity value internalized by the urban land market may depend on the nature of the rural land controls involved. In Britain, where rural 
landowners were compensated for their negotiated speculative losses, and ministerial "permission" to urbanize greenbelts is made exceedingly difficult, the urban land market is expected to internalize greenbelt proximity as an amenity. This is because Britain has virtually purchased the development rights of rural land, and urban landowners proximate to these greenbelts have some certainty about their long term status. However, Oregon's program provides no compensation for speculative losses resulting from EFU zoning (similar to Rosser's "conservancy" zoning). In fact, policy documents suggest that, because the UGB may be pushed into EFU areas over time, explicit compensation for near term speculative losses is not necessary (see, e.g., Mid-Willamette Valley Council of Governments, 1972a).

Hitherto, theoretical and empirical efforts have not specifically determined that the urban land market will value proximity to privately owned greenbelts as an amenity. Boal (1970) and Rosser (1978) address the issue of privately owred greenbelts, but they indicate that conservancy zoning and UGBs should only effect a gap in land values, as shown in Fig. 2.7. This researcher rather theorizes that, under the condition of containing urbanization within UGBs and limiting rural land to greenbelt uses (by subjecting it to conservancy zoning), the urbail land market will assign a premium to greenbelt proximity and land value will increase from $P_{1}$ to $P_{2}$ at $u_{2}$. The amenity but should have the property of diminishing returns. If conservancy zoning is not implemented beyond the UGB, and rural 1 and is allowed to develop into a pattern of low density urban sprawl, then this amenity should not be detectable. 


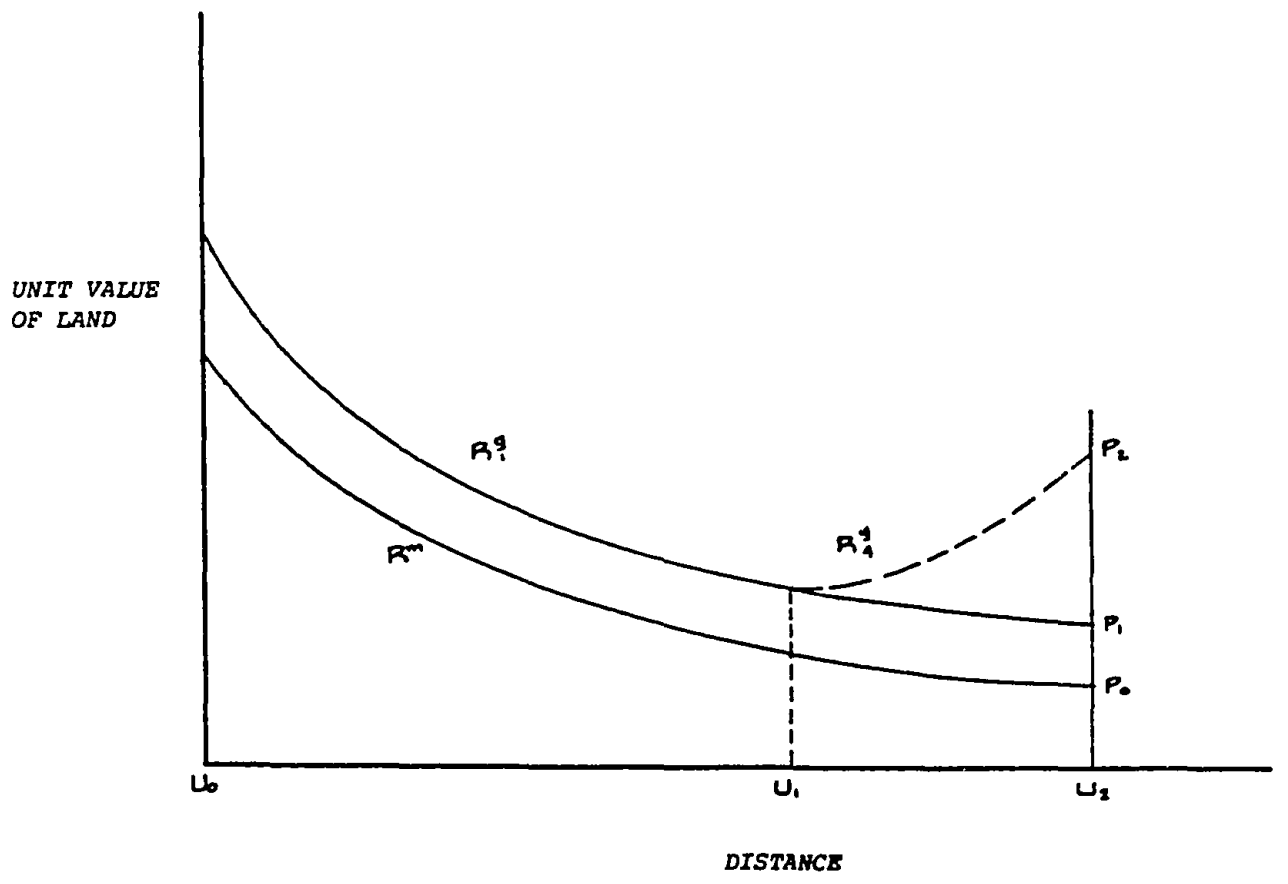

FIGURE 2.7: CREATING AN AMENITY IN THE URBAN LAND MARKET. When an urban containment program effects creation of a greenbelt surrounding urban areas, as in imposing conservancy zoning on rural land, then the urban ?and market values greenbelt proximity as an amenity. Where the greenbelt is coterminous with an urban growth boundary at $u_{2}$, the amenity value is represented by $R_{4}^{9}$. 


\section{UNIFYING THESE THEORIES}

Fig. 2.8 unifies these theories into one which accounts for several outiomes to urban containment programs. Assuming a competitive market where the locus of land values comprises the land value gradient $R^{m}$, an urban containment program which limits urbanization at $u_{2}$, should have the effect of creating a gap in the locus of 1 and values at $u_{2}$. If conservancy zoning is not imposed on rural 1 and, thus allowing rural land to develop into a pattern of low density urban sprawl, then the land value gradient will be shifted from $R^{m}$ to $\mathrm{R}_{1}$.

Where an urban containment program also includes conservancy zoning beyond $u_{2}$, speculative use land value is removed from the area $\mathrm{u}_{2} \mathrm{u}_{4}$ and the underlying agricultural use land value gradient, $\mathrm{Rg}_{2}$, is revealed. Over time, the agricultural use land value will shift upward to $\mathrm{Rg}_{3}$, because farmers will be insulated from urbanizing influences and they will increase agricultural investment and productivity. The form of this gradient will remain the same, however, because land proximate to urban development will remain negatively influenced by proximate urban uses. Under these conditions, urban land proximate to the greenbelt delineated by a UGB imposed at $u_{2}$ will value its proximity as an amenity between $u_{2}$ and $u_{1}$, and the urban land value gradient will appear as $R^{9}$ in this area. 


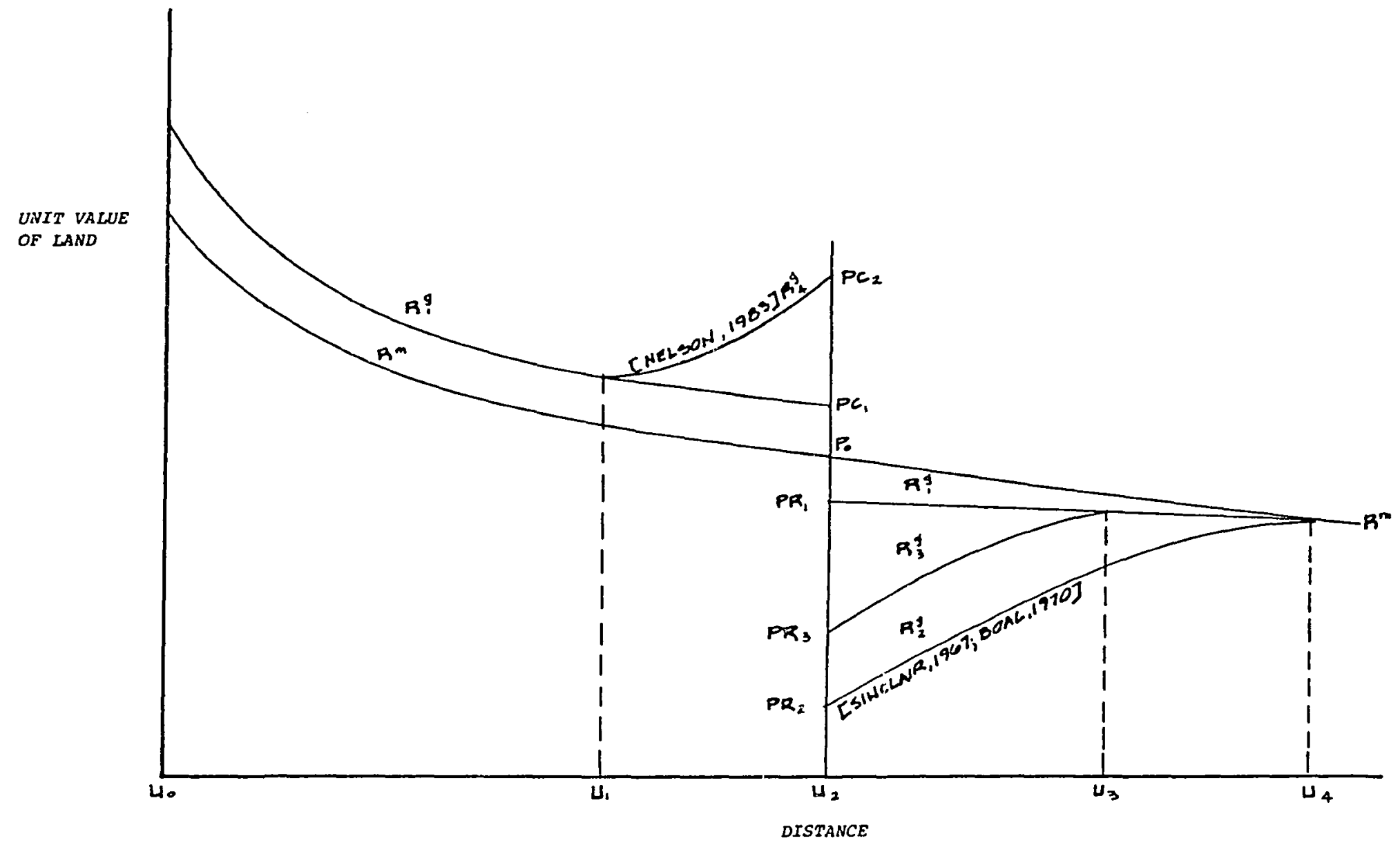

FIGURE 2.8 THE UNIFIED THEORY OF THE EFFECTS OF URBAN CONTAIIMENT PROGRAMS ON URBAN-RURAL LAND VALUES. 


\section{CHAPTER 3}

\section{A Model to Evaluate Urban Containment Programs}

Urban containment proyrams may be evaluated by comparing the performance of policy attributes estimated from a model of the urban-

rural land market to the unified theory presented in Chapter 2. In this chapter: (1) a general model to evaluate urban containment programs is presented: (2) the research setting and nature of the data available to evaluate the performance of Salem's urban containment program is reviewed, and; (3) the model employed in this research to evaluate Salem's program is specified.

\section{A. A GENERAL MODEL}

There are three fundamental land value determination theories: (a) classical rent theory; (b) speculative theory, and; (c) investment theory. Classical rent theory views land value as determined by variations in the inherent productivity and accessibility between parcels. Following Ricardo, productivity models explain differences in agricultural land values. Accessibility models of vacant 1 and value were originally developed by Von Thuenen and later adapted by Aionso (1960, 1964) and Muth (1961, 1969) to the urban-rural fringe. Some theorists - notably Clawson (1971) - view land value as highly influenced by land and development speculators. Others - such as Bahl (1968), Shoup (1970), Adams, et al. (1968), and Kaiser, et al. (1968) - view land valuation as the result of rational investment calculations where prospective purchasers discount the future expected use value of undeveloped 1 and to estimate a present value net of holding costs (such as property taxes, management, etc). 
Witte and Long (1980) conclude that none of these models receive consistently high ratings in terms of their ability to: (a) provide thorough theoretical explanations of land vaiue; (b) cxp?ain the variations in land value; (c) enjoy readily available data, and; (d) have interpretable outcomes. Their evaluation scheme rates accessibility models slightly higher than productivity, speculative and investment models. To improve the performance of vacant land models, they suggest an eclectic model comprised of these models' salient features and features of the hedonic model of land value where land is occupied by structures. While classical rent theory views land as a homogeneous good, Witte and Long contend that it is a nonhomogeneous good with multiple site and bidder attributes affecting its productivity and unit value. Their model explains the variation of unit value of vacant land as a function of: (a) site attributes (SA) such as accessibility, public policy constraints on the parcel including urban containment policies, size and shape, topography and soil characteristics, externality or neighborhood factors, availability of services such as water and sewer, and environmental quality; and (b) bidder attributes including holding costs (HC) such as property taxes and other assessments, income (I) derivable from vacant land uses such as crops and parking, future development possibilities (DP), ownership and title factors (OC) which may affect saies prices, tax law and portfolio considerations of bidders (TL), and the risk and return of alternative investment opportunities (RRa):

$$
P=f(S A, I, H C, D P, O C, T L, R R a) \text {. }
$$


They suggest that their model may reveal the underlying valuation of vacant land if land supply is perfectly inelastic and bidder characteristics vary. They aiso suggest that, decause short-run owner reservation prices and other ownership characteristics may give some elasticity to the vacant parcel supply curve, the underlying valuation of parcel attributes may only be estimated using Rosen's (1974) twostep procedure. Otherwise, the model is considered in reduced form and coefficients are interpretable as implicit prices. In either case, when the vector of site attributes includes urban containment attributes (such as differential zoning) then, by holding all other attributes constant, the model will estimate price differentials of vacant land value attributable to those urban containment factors. Thus, it appears that a model of the unified theory of urban containment effects on land values may be constructed consistent with either the traditional accessibility or Witte \& Long's eclectic approaches, depending on data availability and characteristics.

\section{B. RESEARCH SETTING AND DATA CHARACTERISTICS}

This dissertation selected the urban containment program of Salem, Oregon, for evaluation because of its many research conveniences, including: (a) its recognition as the quintessential urban containment program in Oregon, if not America; (b) its use as the precedent cited by Oregon's LCDC for requiring urban containment programs of all urban areas statewide; (c) its physical setting - it is not complicated by extensive suburban development or spillover growth from proximate major urban areas, and it is situated on a 
modestly flat to gently rolling plain; (d) its differential urban development pattern - urban development is largely proximate to its northern UGB but not to its southern UGB, and conservancy zoning is largely imposed on rural land proximate to its northern UGB while rural residential zoning is largely imposed on rural land proximate to its southern UGB, and; (e) its use as the subject of previous research efforts. This section will review the nature of Salem's growth and policy responses to it, the selection of an appropriate period of study, and the nature of available data.

The Salem SMSA comprises two counties and over one-quarter of a million inhabitants, about half of whom reside within the Salem UGB. The UGB contains the cities of Salem and Kaizer (formally incorporated in 1982) with 1980 populations of about 90,000 and 30,000 respectively. Salem is Oregon's capital city and Marion County seat. Between 1960 and 1980, Marion County's population increased by 65\% (70,000 people) and its supply of farmland decreased by $12 \%, \quad(45,000$ acres). Development of unincorporated areas became the focus of broad-based public efforts to contain urbanization particularly within the Salem region. For example, in 1970-71 over 2,000 acres of unincorporated land were subdivided and provided with urban leve? services. By early 1975, Marion County and neighboring Polk Count:, together with the City of Salem, had installed a UGB and imposed conservancy zoning in prime agricultural areas beyond it. The UGB was slightly modified between its initial adoption in 1974-75 and LCDC's approval of it in 1981. For this analysis, the subject UGB is that approved by Marion County on April 11, 1979 and shown in Plate 3.1. 


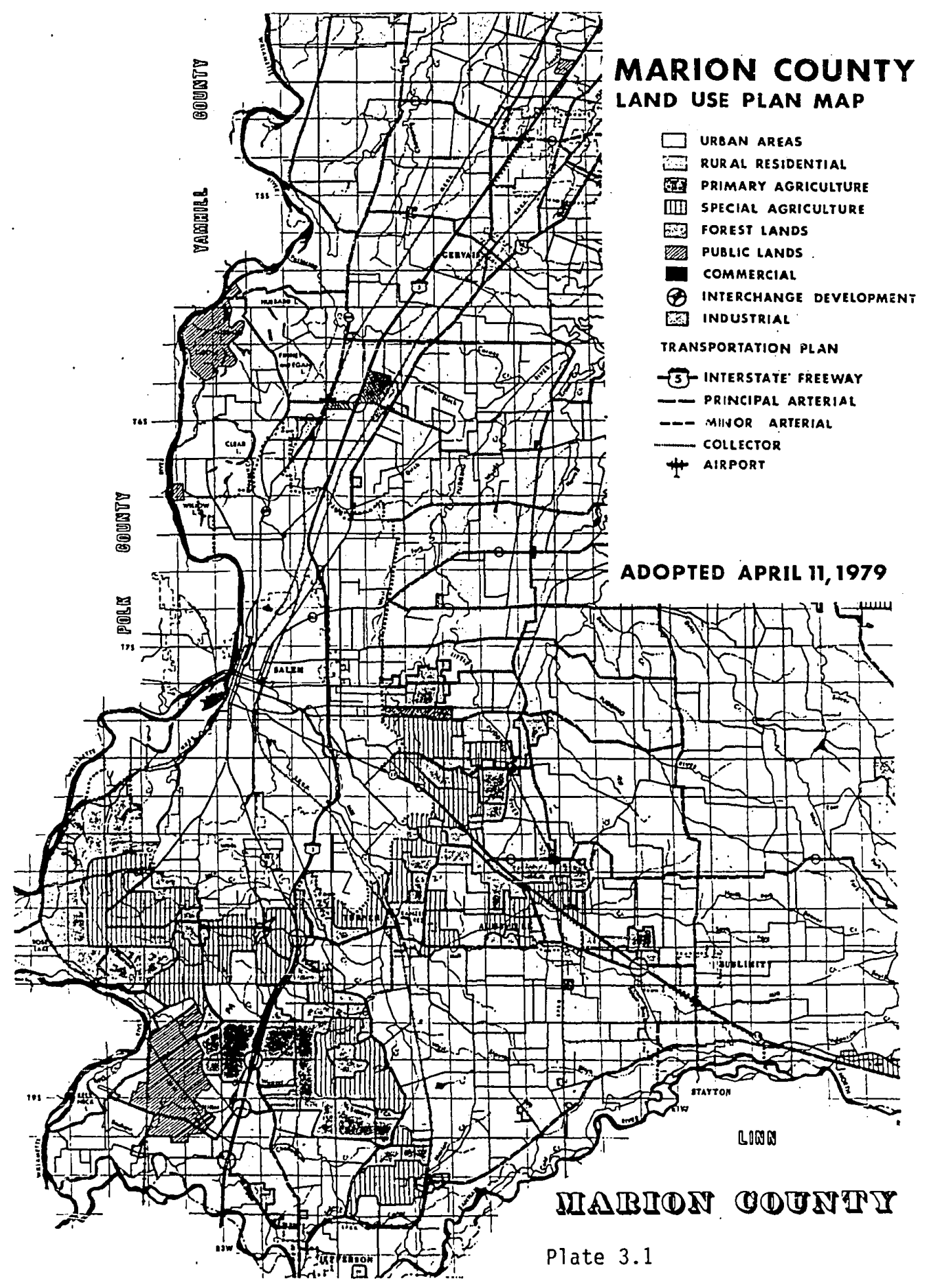


The research period is limited to the period of September 1, 1977 to August 31, 1979 because: (a) it commences about three years after initial adoption of the UGB and about two years after conservancy zoning was completed, thus providing some time for the local land market to internalize these policy influences; (b) it represents a period of time when Salem experienced rapid growth; (c) it precedes by only a few months the beginning of Oregon's 1980 recession; (d) it precedes by a few months the rapid increases in the prime lending and mortgage rates, and; (e) an adequate number of residential and rural vacant land sales occurred.

Two hundred and nine sales of vacant residentially zoned urban land and rural land in Marion County, exceeding nine-tenths of an acre but less than 100 acres in size, and situated within and roughly three miles beyond the UGB, constitute the universe of qualified vacant land sales occurring during the study period. The universe does not include vacant land sold subsequent to urban subdivision approval, or sales apparently involving relatives and closely-held corporations, or trades involving tangible property of unspecified value.

Sources of readily available data include recorded sale instruments, county zoning maps, soils data and maps provided by the USDA Soil Conservation Service, facility maps provided by the City of Salem, census information, county Tax Collector data and maps, and county Assessor files. These data allow specification of: unit sale prices, accessibility, parcel size, soil characteristics and topography (indirectly), availability of urban services, urban containment policies generally and zoning particularly, property tax 
level, neighborhood characteristics - to the extent reported by the census and only at the census tract level, and time of sale.

Site attributes which cannot be specified due to available data and resource limitations include (a) specific on-site characteristics such as topography, drainage, views, and the availability and suitability of alternative water and sewer sources - such as wells and septic systems; (b) certain neighborhood effects such as crime rates and dilapidation levels, and; (c) air and water quality.

Because resources limited data collection to secondary public sources, bidder information is not included in this research. In addition, because a large porportion of all sales were recorded by memoranda, specific sale terms such as interest rate and payment schedule were not available and calculation of present values was not possible. However, property tax and zoning information may give some indication of bidder behavior with respect to holding costs and development possibilities.

The spatial distribution of urban and rural activity in the study area may reveal the conditions under which aspects of the unified theory can be found. For example, while conservancy zoning is applied extensively to farmland proximate to the UGB in North Salem, rural residential zoning is applied extensively to rural land proximate to the UGB in South Salem. Since urban containment programs intend to remove speculative use value of rural land, separate evaluations of the northern and southern regions may reveal the conditions under which this outcome may be realized. Plate 3.1 illustrates the pattern of conservancy and rural residential zoning in the study area. 
Second, the conditions under which the urban land market internalizes greenbelt proximity as an amenity may be determined by separately evaluating the urban North and South Salem. In the northern region, urban development is largely proximate to the UGB and the UGB itself delineates the conservancy-zoned farmlanc's cumprising a greenbelt. In the southern region, urban development is largely some distance from the UGB and land beyond the UGB is allowed to develop into a pattern of low density urban sprawl. Plate 3.2 illustrates where urban development is generally proximate to the UGB.

\section{MODEL SPECIFICATION AND PERFORMANCE EXPECTATIONS}

Based on the characteristics of available data, a model is developed to evaluate Salem's urban containment program in terms of the unified theory. The model is in reduced form and is similar to accessibility models based on classical rent theory. The model will attempt to explain the variation in per acre price of land (PACRE) as a function of parcel size (SIZE), month in which the sale occured (TIME), soil quality, related topographical features, and septic suitability (SOILS), neighborhood influences proxied by the average household income at the census tract level (INCOME), purchase characteristics (TERMS), holding costs in terms of property taxes (TAX), the availability of urban utilities, notably water and sewer (SERVICES), accessibility in terms of distance from the central business district (DCBD), incidence of rural residential (RR) zoning, and urban containment policies (UGB):

$$
\text { PACRE }=f(\text { SIZE, TIME, SOILS, INCOME, TERMS, TAX, SERVICES, RR, OCBD UGB). }
$$




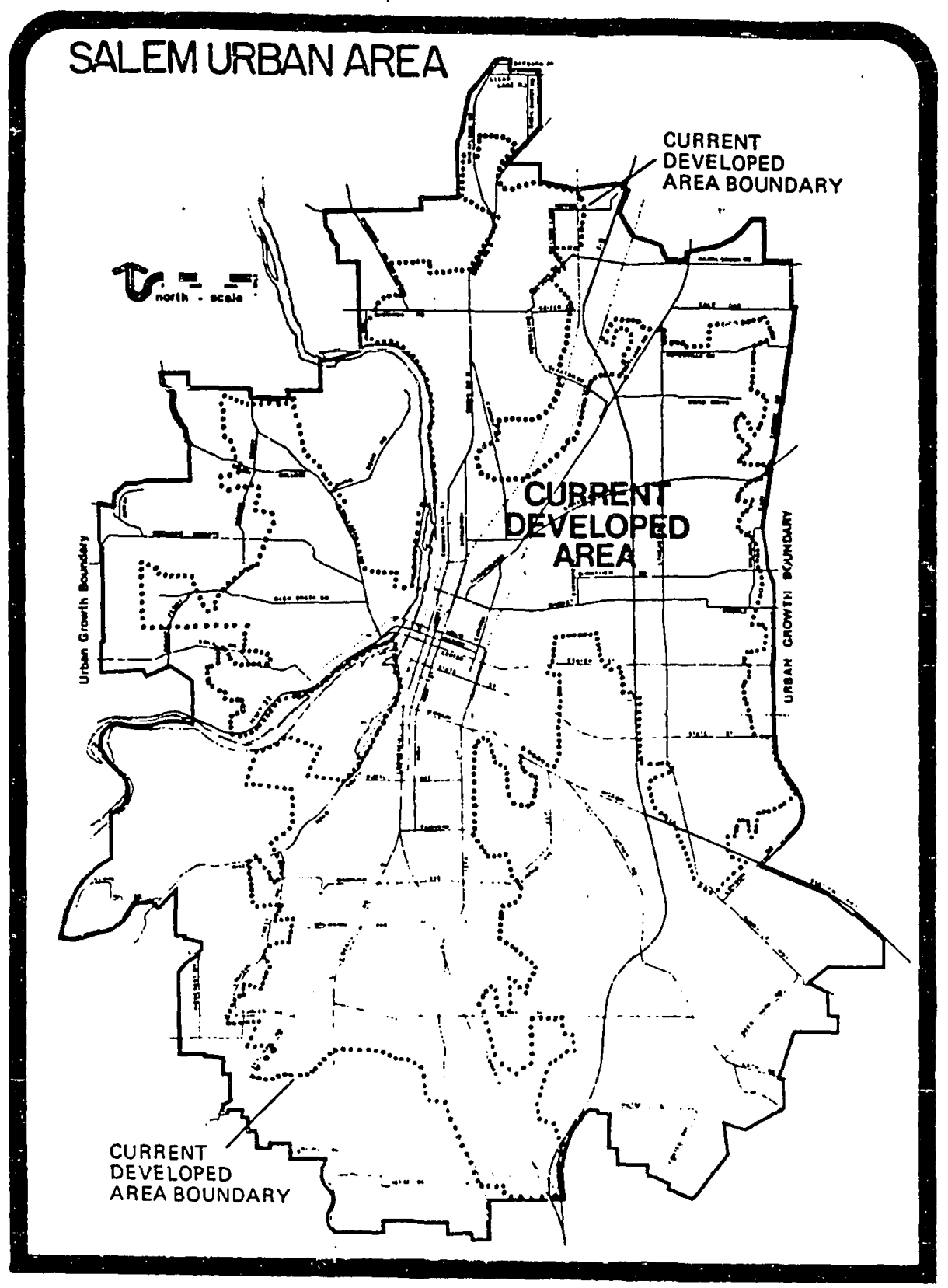

As revised and adopted July 23, 1979, by the Silen City Council.

Plate 3.2 Extent of urban development in Salem, Oregon, 1979. 


\section{Attribute Specification}

The attributes of this model are essentially site-related. However, the TIME, TAX and TERMS attributes may indicate bidder behavior with respect to changing market conditions over time, property tax effects on holding decisions, and financing arrangements which may affect holding and development decisions. In most instances, these attributes are conventionally specified.

\section{(a). SIZE}

Urban economists such as Ratcliff (1949), and Smith, Tschapat and Racster (1977) suggest that land value per unit initially increases at an increasing rate and then decreases at a decreasing rate as lot size increases. Hushak and Sadr (1979) note that the relationship between unit land price and parcel size is highly nonlinear because the nearly constant cost of subdividing is spread over less area as parcel size declines. Colwell and Sirmans (1978) theorize and empirically demonstrate the existence of "plottage" and "plattage" value of land. "Plottage" value occurs when land value increases as a function of land assemblage, providing owners with greater development flexibility. "Plattage" value occurs when land value increases as a function of parcelization, providing owners with greater return from parcelization. Plottage and plattage may occur simultaneously in a land market. Colwell and Sirmans report an empirical investigation revealing (a) plottage to occur at aggregated parcel sizes of less than about one-quarter acre and (b) plattage to occur at aggregated 
parcel sizes greater than about one-half acre. Chicoine (1981) reported that plattage existed in his investigation of $\mathrm{farm} l$ and values at the urban fringe - where the minimum case size was one acre.

The nonlinear relationship between unit land price and parcel size is typically expressed in quadratic or log form. Expecting only the possibility of a negative association between area and unit land price, Clonts (1970), Hushak (1975), Richardson, Vipond and Furbey (1974), and Gleeson (1979), utilized the quadratic form. Expressing SIZE in the quadratic form appears acceptable when only plattage is expected in a local land market or when parcel sizes exceed about one acre.

(b). IIME

The influence of time on land value may be measured continuously by year (Colwell and Sirmans, 1978; Boyce, 1972; Richardson, Vipond, Furbey, 1974)) or month (Chicoine, 1981). The coefficient of TIME is expected to be positively associated with land value. In a semi-log model, TIME may be interpreted as an inflation rate. In a linear mode1, TIME may be interpreted as the average amount of change per unit of TIME - not as conveniently interpretable as the semi-log model allows but acceptable when a study period does not cover more than just a few years. Rather than deflating sales prices by regional or national consumer price deflators, TIME has the advantage of indicating local inflationary tendencies and changing market conditions over time - such as the effect of urban containment programs. In this research, TIME is measured continuously in months. 
(c). SOILS

Continuously measured soil indexas allow estimation of the influence which soil productivity has on agricultural land values (Chicoine, 1981). Alternatively, if urban factors dominate in the urban-rural fringe, septic-suitability of soils is the fundamental market concern about soil quality and its influence may be proxied by a binary septic-suitability soils attribute (Chicoine, 1981; Gleeson, 1979). For Marion County, the USDA Soil Conservation Service measures animal unit months (AUMS) - the equivalent of one-half ton of pasture feed produced per acre - continuously across all soil types found within the study area. AUMs vary between 9 and 21 within the study area and offer interpretive robustness: as AUM productivity improves for farmers, so do the drainage, topographic, foundation suitability, and excavation features for developers. In all soil groups, however, septic-suitability is virtually constant. This research measures soil quality in terms of AUMs.

\section{(d). INCOME}

The concept of neighborhood quality is among the most often specified land value determinants. Neighborhood quality has been proxied in terms of family or household income (Brigham, 1965; Oates, 1973; Pollakowski, 1973; Kain \& Quigley, 1970; Grether \& Mieszkowski, 1974; and Wieand \& Muth, 1972), structural dilapidation (Mills, 1969; Downing, 1970), education level (Downing, 1970; McDougall, 1976), local school quality (Kain and Quigley, 1970), neighborhood density (Butler, 1982); overcrowding (Reuter, 1973; Crecine, Davis \& Jackson, 
1967; Brigham, 1965), neighborhood racial composition (Maser, 1977; Downing, 1970), and crime rates (Brookshire, et a1., 1982; Smith, 1978), and air and water quality (Ridker \& Henning, 1967; Epp \& A1Ani, 1979). However, 1980 census information indicated little variation of data with respect to dilapidation and overcrowding. In addition, education level did not perform significantly when attempts were made to specify it. Finaliy, adequately disaggregated data for crime rates, school quality, neighborhood density, racial composition and air and water quality were either not available or meaningless for want of satisfactory variation. Given Salem's apparent socioeconomic and environmental homogeneity, a census tract level household INCOME attribute was selected to proxy neighborhood quality.

$$
\text { (e). TERMS }
$$

Nearly half of all of the cases involved seller participation in the form of land sale contracts or trust deeds. However, terms involved in these sales were not reported in about half of such cases. Under Oregon law, one need only record a memorandum indicating sales price, date, parties involved, and very little else. Lacking information on sales terms in these cases, bidder characteristics and seller concessions are not determinable. However, the extent to which terms of sale influence sales prices can be indicated from a binary TERMS attribute. Following Delacy (1983), a positive association between TERMS and PACRE is expected. 
(f). TAX

Bahl (1968) and Shoup (1970) theorize that property taxes (a) are a holding cost, (b) reduce land value, (c) reduce holding periods, and (d) encourage more intensive 1and uses. However, empirical work of Pasour (1972), Hushak (1975) and Hushak and Sadr (1979) suggest that property taxes have a small influence on urban-rural land values. Hushak (1975) implies that only with widely varying tax rates across many jurisdictions can one expect to recover significant TAX coefficients.

Property tax rates observed within the study did not vary notably. However, property tax deferral was accorded about thirteen percent of the urban and rural cases, apparently because they met minimum agricultural production criteria. Qualifying landowners pay property taxes calculated on the agricultural income approach, which has the effect of reducing the effective tax rate to a fraction (ten to twenty percent) of its tax liability under the market value approach. A binary TAX attribute may recover the implicit value of participation in this program. Within the urban area, the TAX coefficient is expected to be positive. On the other hand, five years' property taxes calculated at the current market value of land plus statutory interest become due when land is converted from agricultural to urban uses. Thus, short term advantages to participation may be negligible and the TAX coefficient may be negative if the bidder discounts the market price by the value of deferred taxes. The TAX coefficient is expected to be negative among 
rural cases because policymakers will view participation as prima facie evidence that the land is in productive farm use and it should not be converted accordingly; landowners anticipating urbanization therefore tend not to enroll in deferral programs (Hanson \& Schwartz, 1975).

\section{(g). SERVICES}

Goldberg (1974) and Goldterg and Ulinder (1976) report that access to trunk sewers is one of the four considerations of residential land developers. Adams, et al. (1968), estimated that the availability of trunk sewer lines increased the value of undeveloped land by an average of 75 percent. Gleeson (1979) reports that proximity to water and sewer mains and laterals has positive influences on land values. The influence of urban services on 1 and values appear adequately measured by binary attributes. In this research, cases were either adjacent to both water and sewer, or not.

(h). $\underline{R R}$

Within the study area, all cases situated inside the UGB are zoned for single family residential development at the same density, though any given subdivision may be approved for more or less than the zoning standard. Within the rural area however, three zones are applied to two different classes of land. The most productive farmland in the region is generally subject to "exclusive farm use" (EFU) zoning, which severely restricts land uses and parcelization. "special agricultural" and "rural residential" zoning affect the 
balance of rural land in the study area. These are considered "Targe lot" (five to forty acre) and "smaill lot" (two to five acre) rural residential zones. A binary RR attribute allows differentiation between rural parcels subject to EFU or rurai residential zoning. Due to the restrictions of EFU zoning, iarid value should be positiveiy associated with RR designation.

(i). $\underline{D C B D}$

Classical rent theory views land as having the property of diminishing returns with respect to distance from the CBD (Alonso, 1960, 1964; Muth, 1961, 1969; Mills, 1969, 1972). While some have considered accessibility in terms of driving time from the CBD and/or accessibility to nearby freeways and major streets, Mills (1969) concludes from his review of empirical work that it is adequately measured in terms of airline distance from the CBD. While the land value function will be negative-curvilinear with respect to distance from the CBD, empirical work suggests that a linear function is expected within the band around an urban area constituting the urbanrural fringe (Wieand and Muth, 1972; Alonso, 1964; Richardson, Vipond and Furbey, 1974; Hushak and Saúr, 1979; Diamond, 1980). This research specifies distance from the CBD linearly. A negative association is expected between "DCBD" and PACRE. 
(j). UGB

The unified theory expects urban containment programs to affect urban-rural land values in three ways: (1) segmenting the urban-rural land market - or otherwise creating an excessive demand for urban land - resulting in a gap in the locus of land values at the UGB, (2) removing speculation in the agricultural land market and (3) creating a greenbelt proximity amenity in the urban land market. The UGB attribute is specified differentiy for models testing for each of these aspects.

\section{(1). Market Segmentation}

Market segmentation can be indicated by a Chow (F) test of submarkets (Freeman, 1978; see also Nelson, 1978), or a binary attribute segmenting cases spatially (Freeman, 1979; see also Gleeson, 1979; Beaton, et al., 1977) or socieconomically (Becker, 1957; Harrison and Rubinfeld, 1978; Schnare and Struyk, 1976). While this dissertation focuses attention on the binary approach, the Chow procedure employed initially to test the null hypothesis that the price functions of the "urban" and "rural" submarkets are the same. The Chow test defines the restricted sums of squares as deriving from a pooled urban-rural regression equation and the unrestricted sums of squares as deriving from separate urban and rural regression equations. These equations do not include the UGB attribute. The Chow test F-ratio calculated here is significant at the 0.01 level, and the null hypothesis that the price functions of the urban and 
rural submarkets are similar is rejected (see Appendix). This test does not indicate whether the price functions were similar prior to urban containment policies.

The unified theory expects that an urban containment program will result in a gap in the locus of urban and rural land values at the $U G B$, indicating that market segmentation has been effected. The gap may be manifested as a significant coefficient on a binary UGB attribute, which is specified to indicate whether cases are located on the "urban" (1) or "rural" (0) side of the UGB. Results from this approach are reported in Chapter 4.

\section{(2). Eliminating Speculative Use Value of Greenbelts}

If conservancy zoning (Rosser, 1978) effects creation of a greenbelt and eliminates speculative use land value of farmland, then the land value gradient proximate to urban development should conform to the convex quadratic polynomial theorized by Sinclair (1967) and Boal (1970). The UGB attribute specified in (1) may be substituted by two attributes representing this quadratric polynomial; the first measuring distance from the UGB in units uí one hundred feet, "DUGB", and the second being the squared transformation of the first, "DUGB2". (Because northern and southern rural cases are subject to different urban development proximity and zoning conditions, this researcher suspected that the price functions of these rural submarkets were not

the same; the Chow test F-ratio, reported in the Appendix, supported this suspicion because it was significant at the 0.01 level, thus allowing for rejection of the null hypothesis that their price 
functions were the same.) Under conditions where conservancy zoning is imposed on farmland proximate to urban development and the UGB, as found in the northern region, the DUGB attribute should be positively associated with PACRE and the DUGB2 attribute should be negatively associated. On the other hand, under conditions found in the southern region where rural residential zoning is imposed on rural land, suggesting that low density urban sprawl is allowed, the sign of the DUGB coefficient should be negative; the sign expected of the DUGB2 coefficient is not determinable under the unified theory.

Because thirty-nine of the one-hundred-twenty-seven rural cases are proximate to a portion of the UGB delineating the state's extensive prison farm, a bible college, and other irstitutional land not intended for development, interpreting UGB proximity influences on these cases may be problematic. While land value is expected to be negatively associated with prison proximity, the same may not be true for proximity to extensive prison farms and bible colleges. Twentyeight of these cases are interrupted in their line-of-sight to urban development by these institutional properties, and they are excluded from the rural UGB proximity regressions, therefore. The remaining cases are within direct line-of-site of urban development and are included accordingly. (A regression equation which identified these particular cases in a binary attribute resulted in an insignificant coefficient on that attribute; all other attributes remained reasonably stable. The results of this procedure are reported in the Appendix). 
(c). Greenbelt Proximity as an Amenity

If Salem's urban containment program effects creation of a greenbelt, then the unified theory expects the urban land market to value proximity to it as an amenity and the resulting land value gradient should appear as concave quadratic polynomial with respect to distance from the UGB. (Because conservancy zoning is imposed only on rural cases beyond the northern region UGB, there may not be a detectable greenbelt amenity in the southern section of the urban land market. Support for the suspicion that the price functions of the northern and southern urban land submarkets are not similar is indicated by a Chow-test F-ratio, which is significant at the 0.01 level and results in rejection of the null hypothesis. This procedure is reported in the Appendix.) Separate northern and southern urban land market regression equations are reported in Chapter 4. The sign of the OUGB coefficient in the northern regression equation should be negatively associated with PACRE, while the sign of the DUGB2 coefficient should be positive. Alternatively, the sign of the DUGB coefficient should be negative in the southern regression equation, but the unified theory does not expect a determinable sign for the DUGB2 coefficient.

\section{(k). Specification Summary}

The model employed in this research to evaluate the performance of Salem's urban containment program is:

$$
\text { PACRE }=f(\text { SIZE, TIME, SOILS, INCOME, TERMS, TAX, SERVICES, RR, DCBD, DUGB) }
$$


where: PACRE is the parcel sales price per acre, SIZE is parcel acreage, TIME is month in which parcel sale took place $10=$ September, 1977 and 23 = August, 1979), SOILS is parcel AUM rating (sometimes averaged where more than one soil rating is observed), INCOME is the average household income of the census tract within which a parcel is located, in units of one hundred dollars, TERMS indicates whether the parcel sold for cash (0) or involved seller financing (1), TAY indicates whether parcel enjoyed property tax deferral (1) or not (0), SERVICES indicates whether parcel was adjacent to both water and sewer (1) or not (0), RR indicates whether rural parcels were subject to EFU restrictions (0) or not (1), DCBD is the parcel distance from the CBD in units of one hundred feet, and UGB indicates either parcel location within (1) or beyond (0) the UGB, a quadratic measure of the distance from the UGB in units of one hundred feet. The means and standard deviations of these attributes for each market specified above are reported in the Appendix.

\section{Modelling and Specification Comments}

Salem's urban containment program was previously evaluated by Beaton, et al. (1977), who reported an insignificant coefficient on i binary UGB attribute. Their modelling apparently suffered from timing and specification problems. First, their research period commenced about one year after major elements of the urban containment program were implemented, leading them to suggest that perhaps the local land market lagged in internalizing the effects of this program. Alternatively, they admit that their UGB attribute suffered from 
modest to high multi-collinearity with respect to CBD distance, their binary School District location attribute, and their binary urban service availability attribute. This research also suffers from modest UGB collinearity with the DCBD and UTILITYS attributes.

Second, they suggest that perhaps both the urban and rural residential land markets were similarly affected by Salem's program. If UGBs restrict the supply of urban land, and if EFU zoning restricts the supply of land remaining available for rural residential use, then perhaps Salem's urban containment program simultaneously creates an excessive demand for urban and rural residential land. Since their model could not indicate this rural residential effect, they suggested that the performance of their UGB attribute may have been biased. This research accounts for this possibility by including the RR attribute.

This research improves upon Beaton's work by: (a) selecting a study period occurring after the locai land market had more time to adjust to urban containment policies, (b) limiting research to one side of the Willamette River (Marion County), (c) extending the period of research over two years, (d) improving specification of the SIZE attribute (their binary SIZE attribute distorted and misspecified the relationship betheen Marion and Folk Councy casesi, and (e) improving model specification by including the SOILS, INCOME, RR, TIME, TERMS and TAX attributes.

This research initially specified a model with only the SIZE, TIME, SERVICES, SOILS, DCBD, RR and UGB (including DUGB and DUGB2) attributes because these were considered to be the most influential 
factors in the local land market. Though these attributes have the most consistently significant and influential coefficients of the various models reported, the additional attributes (TERMS, TAX, and INCOME Jare included for completeness.

Finally, in light of the possibility that Salem's urban-rural land market trades vacant land as a nonhomogeneous commodity, a sales price per parcel (PRICE) dependent variable was entertained. Considering that various regulatory and seller factors prohibit the transfer of land in any denomination desired by bidders, this initial approach was pursued extensively. However, in light of the weight and interpretive influence of land value theory, the unit land value attribute, PACRE, was employed as the appropriate dependent variabli. If unit value empirical efforts are largely considered reduced forms, then modelling a system of simultaneous equations to allow for a variety of interactions between land and other attributes may be a useful avenue of future research.

\section{Choice of Functional Form}

While the model employed here may assume any of several functiona? forms, this researcher was porsuaded to use the linear form for a number of practical reasons. First, it allows for convenient communication of policy influences on land value because the coefficients will generally be in dollars and cents per unit of measure. This may be the reason why a large number of other researchers reporting the effect of urban containment policies on 1 and values have also used the linear functional form (see Correll, 
Lillydahl and Singe11, 1978; Beaton, 1977; Gleeson, 1979; Clonts, 1970; Hushak, 1975; e.g.). Second, if PACRE is logged and distance from the UGB assumes a quadratic functional form, interpreting the association of DUGB and DUGB2 with PACRE is problematic because (a) variation of DUGB and DUGB2 will be especially compressed and (b) conveying to policymakers the effects of policies on land values proximate to the UGB may be unnecessarily complicated. Third, the derivative of DUGB and DUGB2 with respect to PACRE carn indicate the mean distance beyond the UGB wilere urban development does not exert a detectable influence on rural land values, or where greenbelts do not have an amenity effect on urban land values; in this regard, Correll, et al. (1978), lamented their inability to include this particular feature in their analysis.

One possible problem with a linear functional form is the interpretation of the SIZE coefficient, inasmuch as it suggests a quadratic association with respect to PACRE (see Colwell and Sirmans, 1978). This problem is minimized because (a) only plattage value is expected to exist within the study area, (b) only at parcel sizes exceeding the largest case included in this study would the quadratic Function generate problematic interpretations, and (c) inasmuch as this research is chiefly concerned with the linear covariation between UGB and PACRE, specifying SIZE linearly appears adequate.

\section{Expected Results}

For summary convenience, the direction of associations expected between the attributes and land value are presented in Table 3.1. 
TABLE 3.1

EXPECTED DIRECTION OF ASSOCIATIONS BETWEEN

ATTRIBUTE COEFFICIENTS AND PRICE PER ACRE (PACRE)

\begin{tabular}{|c|c|c|c|c|c|}
\hline \multirow{3}{*}{ Attribute } & \multirow{3}{*}{$\begin{array}{l}1 \\
1 \\
1 \\
1 \\
1 \\
1\end{array}$} & \multicolumn{2}{|c|}{ Model } & \multirow[b]{2}{*}{ Urban UGB } & \multirow[b]{2}{*}{ Proximity } \\
\hline & & Rural UGB & Proximity & & \\
\hline & & North & South & North & South \\
\hline SIZE & - & - & - & - & - \\
\hline TIME & + & + & + & + & + \\
\hline SOILS & + & + & + & + & + \\
\hline INCOME & + & + & + & + & + \\
\hline TERMS & + & + & + & + & + \\
\hline TAX & - & - & - & - & - \\
\hline SERVICES & + & & & + & + \\
\hline$R R$ & + & + & * & & \\
\hline DCBD & - & - & - & - & - \\
\hline UGB & + & & & & \\
\hline DUGB & & + & - & - & + \\
\hline DUGB2 & & - & $?$ & + & + \\
\hline
\end{tabular}

*No rural South Salem cases subject to EFU zoning. 


\section{CHAPTER 4}

\section{Results and Interpretations}

Ordinary least squares regressions were performed on each of the market segmentation and UGB proximity models described in Chapter 3, and their results and interpretations are reported here.

\section{A. MARKET SEGMENTATION}

Regression of the market segmentation model:

PACRE $=f($ SIZE, TIME, SOILS, INCOME, TERMS, TAX, SERVICES, RR, DCBD, UGB $)$

provided the following results:

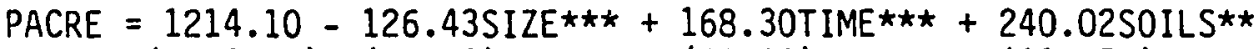

$$
\begin{aligned}
& \begin{array}{llll}
(4571.65) \quad(35.41) \quad(42.03) \quad \text { (116.70) }
\end{array} \\
& +1.48 \text { INCOME - 515.44TERMS - 1141.40TAX + 1946.91SERVICES** } \\
& \begin{array}{llll}
(13.45) & (651.52) & (972.32) & \text { (1148.62) }
\end{array} \\
& +1649.35 R R *-0.520 C B D+3877.88 U G B \star \star \star \\
& \begin{array}{lll}
(1129.47) \quad(6.09) \quad(1380.09)
\end{array} \\
& n=209 ; R^{2}=.33 ; \text { S.E. }=4297.17 ; \text { d.f. }=198 ; \quad F=9.97 \\
& \text { One-tailed significant } t \text {-levels indicated by } \star \star \star=.01, \star \star *=.05 \text {, } \\
& \star=.10 \text {. (Standard error of attribute estimates in parentheses.) }
\end{aligned}
$$

The correlation matrix indicates multicollinearity of: (a) UGB with SERVICES(.76), RR(-.77) and DCBD(-.75); (b) SERVICES with DCBD(.73), and; (c) RR with $\operatorname{DCBD}(.64)$, all of which were expected. Only parcels inside the UGB enjoy SERVICES and only parcels outside the UGB enjoy RR status. Additionally, as one approaches the CBO, the likelihood of also being located within the UGB improves, and the likelihood of RR status deteriorates. These problems of collinearity are endemic to the study area, and not easily avoided (see also Beaton, et al., 
1977); nonetheless, these correlation coefficients possessed signs consistent with a priori expectations about data distribution, and their magnitudes were not excessively high. As regards other equation factors, (a) the F-ratio is significant at the .01 level, (b) there were no signs of systematic bias in the residuals, and (c) significant attribute coefficients possessed the expected signs. The coefficient of determination is on the low side but actually similar to Beaton's (1977). One suspects that a variety of site specific factors (views, highly localized physical development factors such as on-site drainage, driveway and road access considerations, etc) not included in the equation account for much of the unexplained variation.

The coefficients of SIZE, TIME, SOILS, SERVICES, RR and UGB are significant at least at the .10 level, carry the expected signs and have reasonable magnitudes. The SIZE roefficient indicates that land value declines by $\$ 126$ for each additional acre of 1 and. The TIME coefficient indicates that land value increased by an average of $\$ 168$ per acre per month, which converts to a compounded monthly inflation rate of about 1.625 percent. Local appraisers assert that this rate was too high for the rural land market and too low for the urban land market during the period of study. More discussion about the TIME attribute is offered later in this section. The SOILS coefficient indicates that PACRE increases by $\$ 240$ for each addition init of Aưf productivity, a reasonable magnitude according to staff of the USDA Soil Conservation Service. The RR coefficient suggests that rural residential status increases PACRE by $\$ 1649$; this indicates that an excessive demand for RR land may have been created. 
The SERVICES coefficient indicates that availability of both water and sewer adds $\$ 1947$ to the unit value of land. This appears smaller than expected, a priori, and may be due to its collinearity with UGB. For Chow-test purposes, a regression of the same equation without UGB provided a SERVICES coefficient half again higher than this equation (see Appendix). The sum of the SERVICES and UGB coefficient equal about two-thirds of the mean value PACRE, roughly the same magnitude of contribution to the mean unit value of vacant urban land which Adams, et a1. (1968), reported.

The UGB coefficient indicates that the local land market attributes the highest premium to land located inside the UGB. Inasmuch as UGB proxies urban density zoning directly, and is itself somewhat collinear with SERVICES, and DCBD, the UGB coefficient suggests that an urban containment program limiting attractive zoning and urban services to central locations results in a substantial gap in the locus of regional urban-rural land values favoring urban locations. Fig. 4.1 illustrates this effect. Contrary to Beaton's (1977) findings and published interpretations (see, e.g., Jeffrey, 1983), it appears that Salem's urban-rural land market internalized urban land supply restrictions effected by urban containment policies within a far shorter period of time than he predicted.

Whitelaw (1980) suggests another view of market segmentation. Despite his admittedly nonrigorous analysis of the effect that an urban services limit had on urban and rural land in Eugene, Oregon, Whitelaw suggests that urban containment policies will result in diverging urban and rural land inflation rates over time. This 


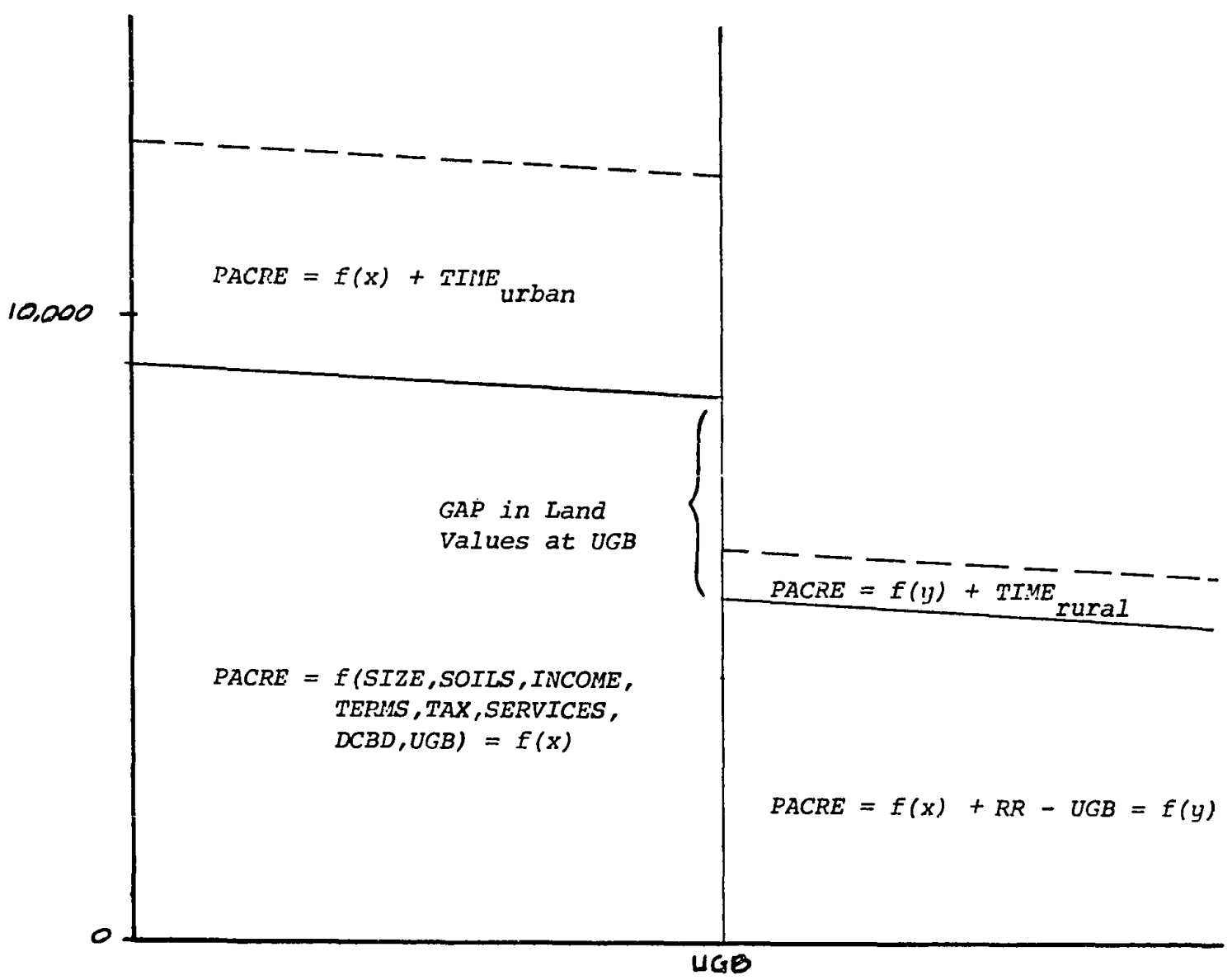

FIGURE 4.1: SEGMENTATION OF THE URBAN-RURAL LAND MARKET IN SALEM, OREGON. The nrociuct of the attribute coeflicients and their means are summed from the Urban-Rural regression equation as indicated. The product of the TIME coefficient and its mean from the separate Urban and Rural regression equations are indicated as increments on this Figure for illustration purposes only. 
effect is treated more rigorously here. Based on the Chow test procedure discussed in Chapter 3, which resulted in separate regression equations for the urban, rural, and pooled cases (see the Appendix), one finds that the urban and rural TIME coefficients fall beyond the ninety-five percent confidence interval of the pooled equation TIME coefficient. The compounded monthly rate of inflation of urban and rural land during the study period was apparentiy 2.2 percent and 0.9 percent, respectively; this is consistent with opinions of local appraisers (interviews, Marion County Department of Assessment and Taxation, indexing personne1, and Powe11, Totten \& Associates; October, 1982). Salem's urban containment program appears to have so adjusted the supply characteristics of the urban-rural fringe land market as to result in widely varying inflation rates between urban and rural submarkets. This effect is noted in Fig. 4.1.

B. SPATIAL INFLUENCES OF CONTAINMENT POLICIES ON RURAL LAND VALUES

Salem's urban containment program applies zoning to rural land differentially. Because conservancy zoning is applied extensively along Salem's northern UGB, where the region's best farmland is also largely proximate to urban development, and rural residential zoning is applied extensively beyond the southern UGB, a Chow test indicated that the price functions of these submarkets are different (see Appendix). Thus, the regression equation:

PACRE $=f($ SIZE, TIME , SOILS, INCOME, TERMS , TAX , RR , DCBD , DUGB , DUGB2)

is applied to these rural submarkets. 
1. Removing Farmland Speculation in Rural North Salem

The rural North Salem regression equation results are:

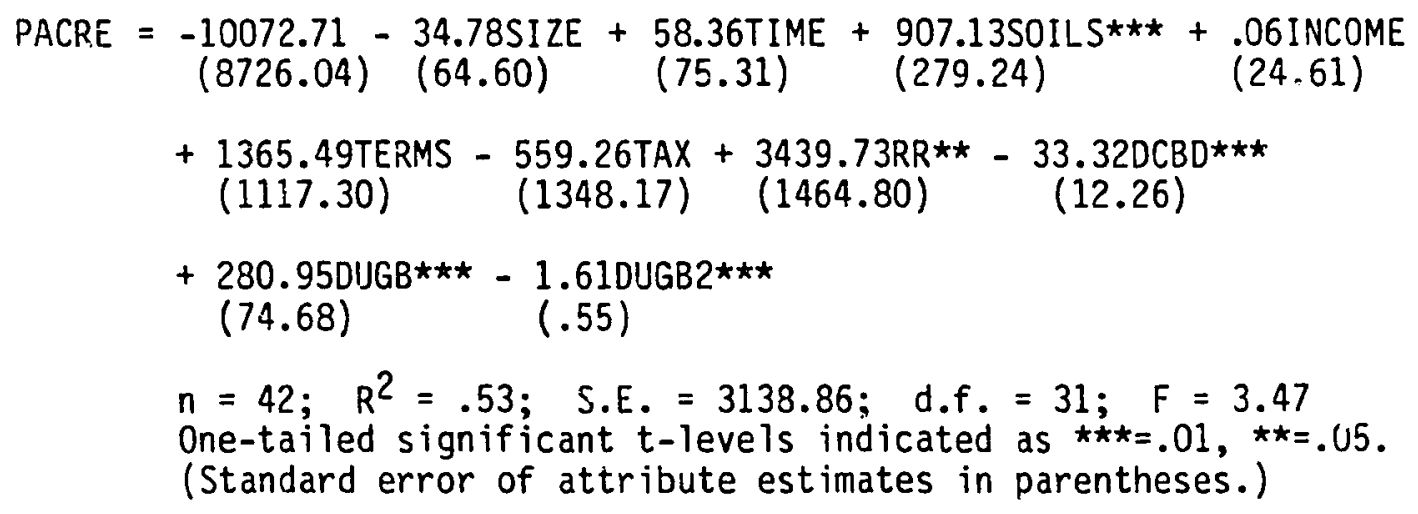

Except for the expected positive correlation of DCBD with DUGB(.66), there was little evidence of multicollinearity in the correlation matrix. In addition: (a) the F-ratio is significant at the .01 level, (b) there are no signs of systematic bias in the residuals, (c) all significant attribute coefficients possessed the expected signs, and (d) the coefficient of determination is of modest size.

The coefficients of SOILS, RR, DCBD, DUGB, and DUGB2 are significant at least at the .10 level, carry the expected signs, and have reasonable magnitudes. It is interesting to note that the SIZE and TIME coefficients are not significant and carry smaller vaiues than those in the urban-rural regression equation. Their performance may indicate that land value in this submarket (a) is linearly associated with size, hence the poor performance of PACRE's nonlinear SIZE attribute, and (b) is not significantly associated with the passage of time. 
The large size of the SOILS coefficient suggests that this submarket puts a premium on higher quality farmland. AUM productivity in this submarket varies considerably, ranging from a high of 21 in the extensive Willamette River bottom land surrounding much of the northern UGB to a low of 14 in the foothills and rural residential areas along and north of the Santiam Highway. It is not surprising to find that, where an agricultural land market operates, land value is substantially sensitive to soil quality. The extent to which conservancy zoning removes alternative use expectations, the agricultural land market is free to assign a premium to AUM productivity. Further evidence of market differentiation between agricultural and rural residential use expectations is provided by a sizeable RR coefficient. This submarket apparently discounts land value where land is subject to conservancy zoning; the size of the RR coefficient also suggests that an excessive demand for land of this designation may have been effected by Salem's program. The DCBD coefficient indicates that land value declines with increasing distance from the CBD in this submarket, as expected.

According to the unified theory, rural value land proximate to Salem's northern UGB shouid conforri to Sinclair's (1967) theorized convex quadratic polynomial agricultural use land value gradient because, according to Boal (1970) and Rosser (1978), the application of conservancy zoning beyond a UGB should effect removal of speculative use value of rural land. Sinclair's theory and Boal's and Rosser's expectations are supported here. The DUGB and DUGB2 coefficients show a convex quadratic polynomial association between 
Tand value and the UGB. By setting the derivative of PACRE with respect to DUGB and DUGB2 at zero, the inhibiting influence of UGB proximity on land value is estimated to reach minima at about 8,500 feet from the UGB. However, because decreasing market proximity also inhibits land values, the land value gradient with respect to DCBD, DUGB and DUGB2 reaches minima at about 7,500 feet. This relationship is illustrated in Fig. 4.2(a).

2. Maintaining Low Density Sprawl in Rural South Salem

The rural South Salem regression equation results are:

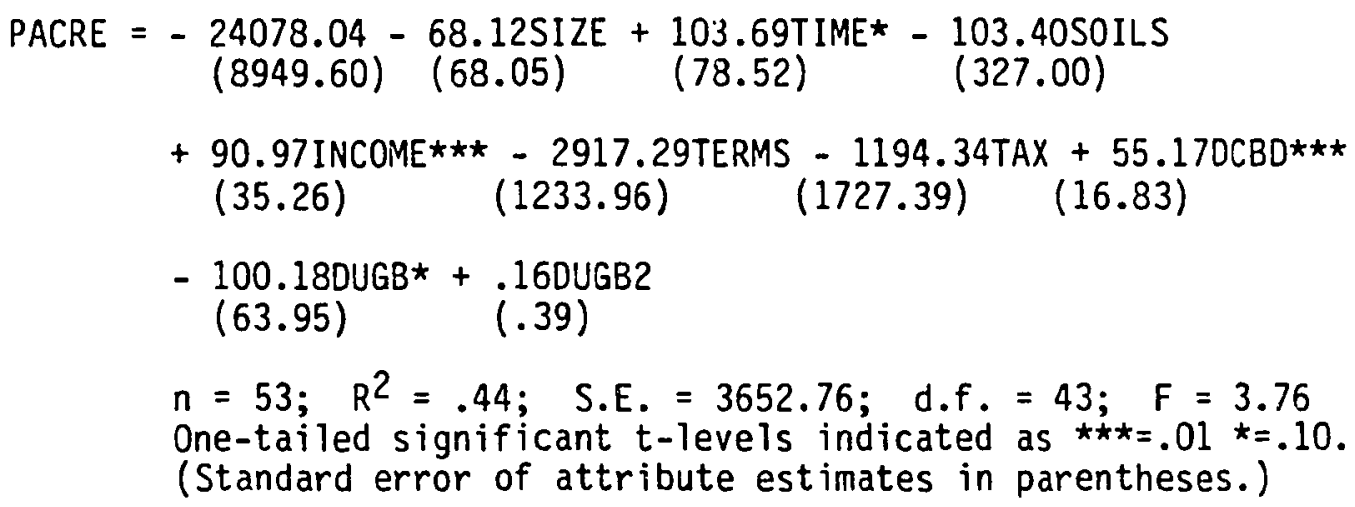

The correlation matrix shows problematic multicollinearity of DCBD with DUGB(.81). While multicollinearity is expected because both measure distance from points of the urban area, the degree of association will require a special note below. In addition: (a) the F-ratio is significant at the .01 level, (b) there were no signs of systematic bias in the residuals, (c) significant coefficients possessed expected signs and, (d) the coefficient of determination is modest. 
The coefficients of the TIME, INCOME, TERMS, OCBD and DUGB are significant at least at the .10 level, but the signs for TERMS and $D C B D$ are contrary to expectations. The quotient of the TIME coefficients with respect to PACRE indicate an average monthly inflation rate of 1.50 percent, which equates to a compounded monthly rate of about 1.30 percent. This rate is consistent with rural residential inflation expectations of local appraisers for the study period. The INCOME coefficient indicates preference for locations within higher income census tracts.

The sign of the TERMS coefficient is contrary to expectations, it would mean that sellers providing their own financing accept sales prices less than their cash value expectations. Records of the County Clerk indicate that cash sales typically preceded home construction many were cashed-out as a result of take-out mortgages. Perhaps because home construction in rural residential areas involves greater public agency review than typical for urban locations - albeit less review than typical for conservancy areas - cash sales may indicate bidder confidence that a home may be constructed on the site. In uncertain situations, financial institutions may be unwilling to provide loans, thus forcing bidders to discount land value for its uncertainty and require seller financing. Lacking individual bidder information, the TERMS result remains a curiosity.

Given their high level of multicollinearity, perhaps the DCBD and DUGB attributes represent similar spatial phenomena. Alternative models, which either excluded DCBD or included a quadratic DCBD but excluded DUGB attributes, resulted in no significant DCBD or DUGB 
coefficients. While the direction of the DCBD coefficient is peculiar, the land value gradient with respect to both DCBD and DUGB is negative, as illustrated in Fig. 4.2(b).

The rural South Salem land value gradient, together with the performance of the TIME, INCOME, and perhaps the TERMS attributes, indicate that this submarket behaves as one might expect under conditions of urban spraw1. This outcome is reasonable given that (a) the area has been extensively zoned for large or small acreage rural residential development, (b) the area does not contain the highly productive soils found throughout rural North Salem, and (c) policymakers appear to have conceded low density urban development in this area in exchange for imposing conservancy zoning elsewhere.

\section{SPATIAL INFLUENCES OF CONTAINMENT POLICIES ON URBAN LAND VALUES}

The pattern of urban development differs betweer. Salem's northern and southern urban areas. Urban development has largely filled in to the UGB in North Salem, but has not largely approached the UGB in South Salem. In addition, the pattern of conservancy and rural residential zoning differs between the northern and southern areas. Conservancy zoning is extensively applied to farmland beyond the urban North Salem UGB, while rural residential zoning is extensively applied beyond the urban South Salem UGB. The influence which rural zoning patterns and spatial urban development constraints have on urban land values may result in different price functions between these urban submarkets. A Chow test of this possibility rejected the null hypothesis that their price functions were stable (see Appendix). 


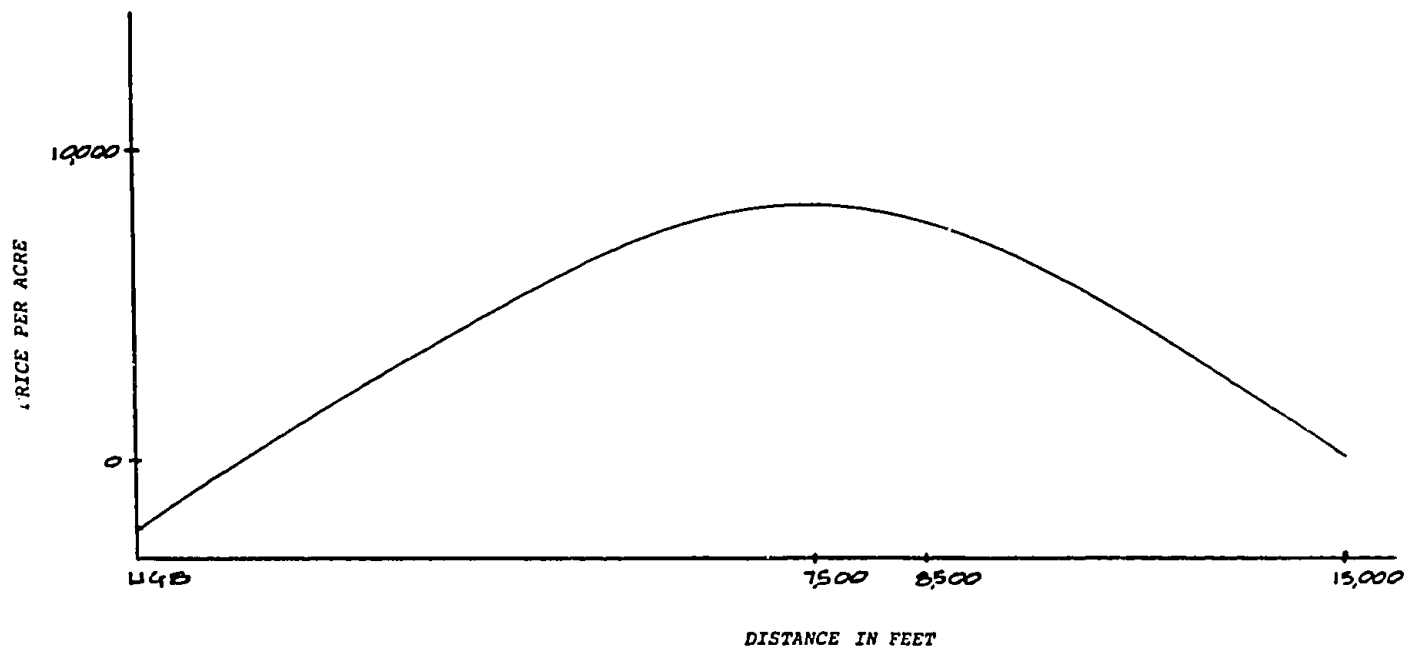

FIGURE 4.2(a): REVEALING THE AGRICULTURAL USE LAND VALUE GRADIENT IN RURAL NORTH SALEM.

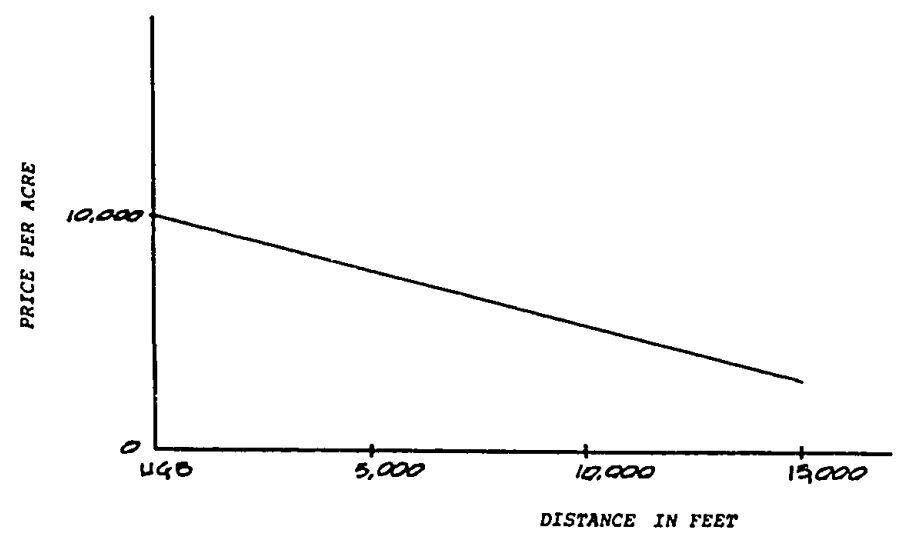

FIGURE $4.2(b)$ : MAINTAINING URBAN LAND VALUE CHARACTERISI'ICS IN RURAL SOUTH SALEM 
Thus, the equation:

PACRE $=f($ SIZE, TIME, SOILS, INCOME, TERMS, TAX , SERVICES , DCBD , DUGB , DUGB2 $)$

is applied separately to each urban submarket.

1. Greenbelt Proximity as an Amenity in Urban North Salem

The urban North Salem regression equation results are:

$$
\begin{aligned}
& \text { PACRE }=\underset{(22816.57)}{22493.49}+\underset{(78.29)}{(26.61 S I Z E}+\underset{(98.49)}{301.71 T I M E * \star *}+\underset{(455.70)}{49.48 S O I L S}-\underset{(60.60)}{25.47 \text { INCOME }} \\
& \text { - 364.88TERMS + 4727.72TAX + 2900.40SSERVICES - 57.49DCBD** } \\
& \begin{array}{llll}
(1369.83) \quad(4243.04) \quad(3006.78) & \text { (32.09) }
\end{array} \\
& -150.290 U G B^{\star}+2.97 D U G B 2 \star \star \\
& (115.01) \quad(1.28) \\
& n=42 ; R^{2}=.62 ; \quad S . E .=3384.26 ; \text { d.f. }=29 ; \quad F=4.78 \\
& \text { One-tailed significant } t \text {-levels indicated as } \star \star \star=.01, \star \star *=.05 \text {, } \\
& \star=.10 \text {. (Standard error of attribute estimates in parentheses.) }
\end{aligned}
$$

The correlation matrix indicates modest multicollinearity of SERVICES with DCBD (.64), which may account for SERVICES' performance. Âs one approaches the CBD, the likelihood of also enjoying urban services improves. In other regards: (a) the F-ratio is sigrificant at the .01 level; (b) there are no signs of systematic bias in the residuals, (c) significant attribute coefficients possessed expected signs and; (d) the coefficient of determination is modestly impressive.

Only the TIME, DCBD, DUGB and DUGB2 coefficients are significant. They carry the expected signs and have reasonable magnitudes. The TIME coefficient indicates a compounded monthly inflation rate of nearly two percent during the study period, a reasonable estimate according to local appraisers. The DCBD coefficient indicates the 
expected negative association between land value and distance from the CBD. The signs and magnitudes of the DUGB and DUGB2 coefficients indicate that UGB proximity is an amenity in this submarket. By setting the derivative of PACRE with respect to DUGB and DUGB2 at zero, the amerity influence of UGB proximity on land value is estimated to reach maxima at about 2,500 feet from the UGB. However, because increasing distance from the CBD inhibits 1 and values, the land value gradient with respect to DCBD, DUGB and DUGB2 reaches maxima at about 1,500 feet from the UGB. Fig. 4.3 illustrates this.

Boal (1970) and Rosser (1978) apparently did not anticipate that the urban land market would internalize greenbelt proximity as an amenity. In this regard, empirical work of Correll, et al. (1978), Hammer, et a1. (1971), and others indicates that urban land proximate to publicly owned greenbelts and large urban parks exclusively enjoys a vector of open space goods. Hitherto, detecting this amenity effect under conditions where open spaces remain in private ownership has not been empirically demonstrated. This research indicates that, where urban development is proximate to a UGB delineating privately owned open spaces subject to conservancy zoning, the urban land market values greenbelt proximity as an amenity. 


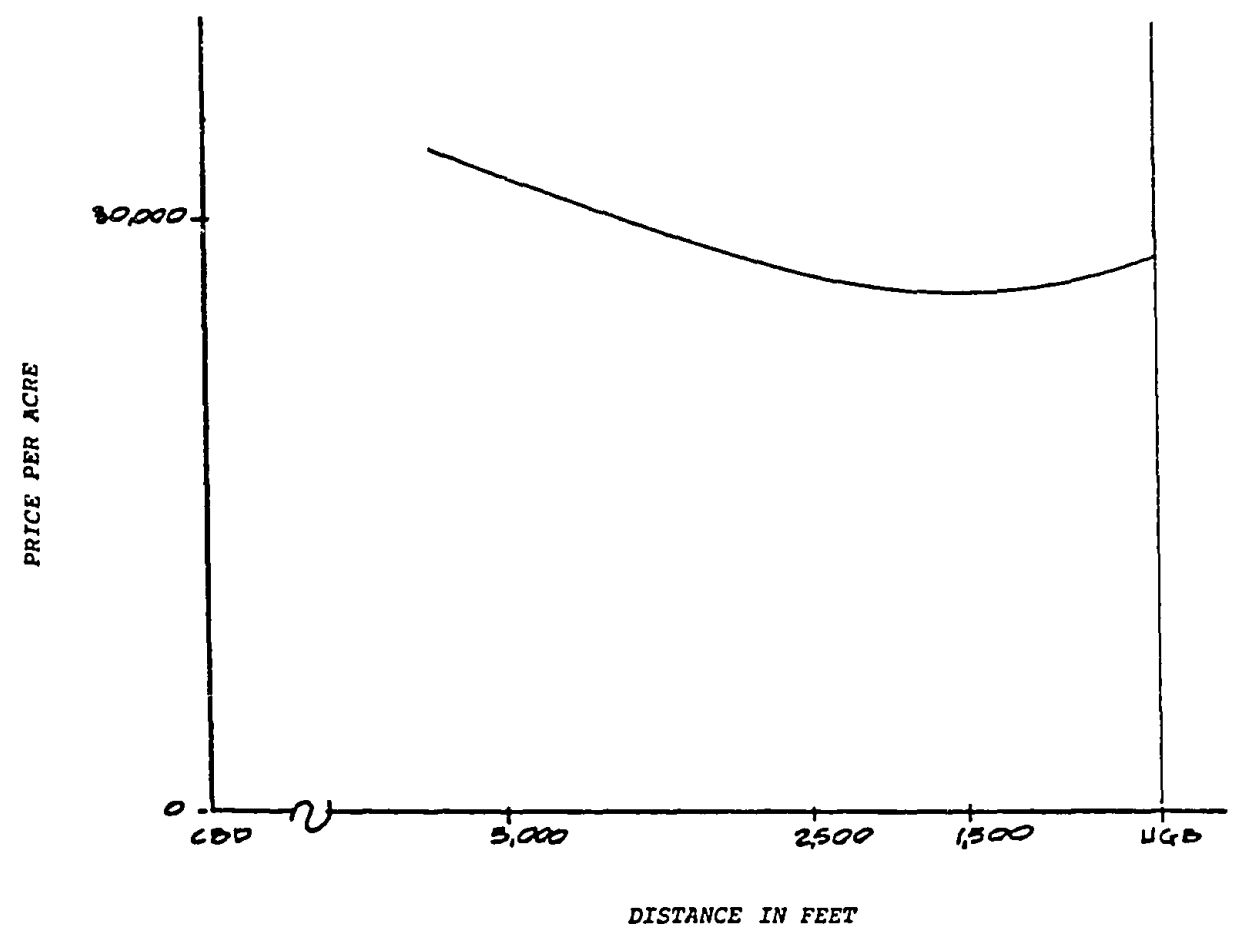

FIGURE 4.3: GREENBELT PROXIMITY AS AIN AMENITY IN URBAN NORTH SALEM. 
2. Disequilibrium in Urban South Salem?

The urban South Salem regression equation results are:

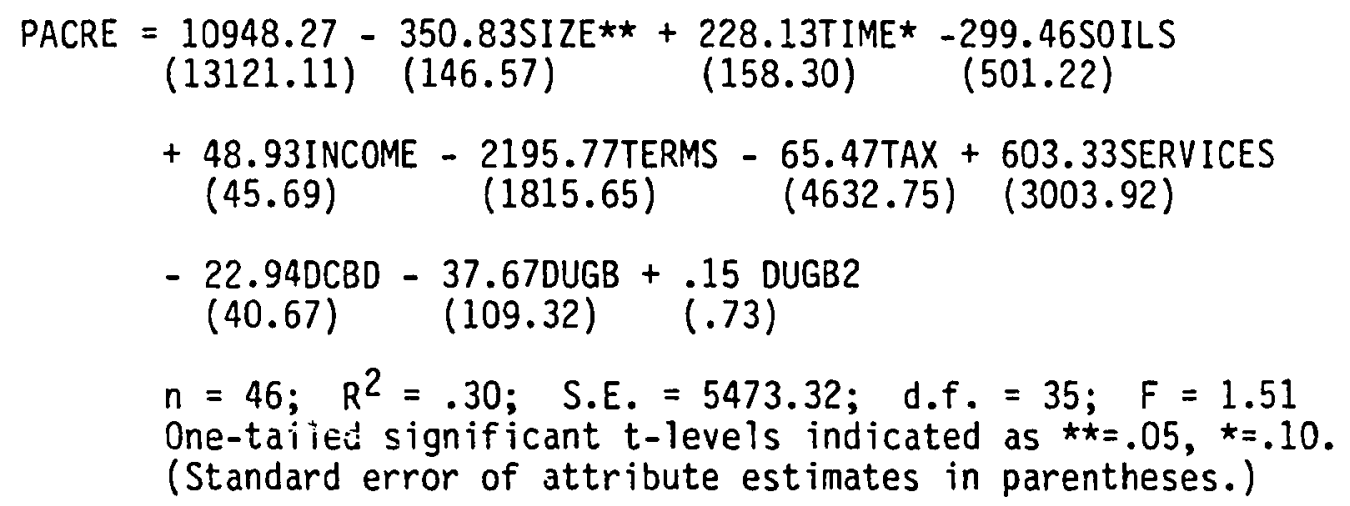

The correlation matrix shows multicollinearity of DCBD with SERVICES(.65) and DUGB(.77), and multicollinearity of DUGB with SERVICES(.63). These associations may explain why none of these attributes performed significantly; as one approaches the CBD, travelling away from the UGB, the likelihood of enjoying urban services increases. In other regards: (a) the F-ratio indicates that the regression equation itself is not significant at any acceptable level; (b) there are no signs of systematic bias in the residuals, significant attribute coefficients possessed the expected signs, and (d) the coefficient of determination is smaller than desired.

Only the SIZE and TIME coefficients are significant. They carry the expected signs and have reasonatle magnitudes. The SIZE coefficient indicates that plattage exists in this submarket. Following Hushak and Sadr (1979), this suggests that the cost of subdividing, which is largely constant, is spread over loss area as parcel size increases. The TIME coefficient indicates a monthly 
compounded inflation rate of 1.85 percent, which is consistent with local appraisers' observations covering the study period.

Given the performance of the regression equation, conclusions based on these results are not reasonably supported. This situation may be addressed by two considerations. First, policymakers appear to have assigned the urban South Salem submarket for substantial urban development. For example, planning documents show that this area is intended to accommodate about 100,000 people, or roughly twice its 1980 population; the area has been well stocked with vacant urbanizable land accordingly. Given that urban South Salem is forced to absorb the majority of the region's urban residential growth, detectable development patterns may not evidence themselves until some time after this submarket has adequately internalized the effects of these policy directives.

Second, even though urban development is generally short of the range of UGB influence, which is limited to 1,500 of the UGB in urban North Salem, this researcher does not expect this submarket to ever value UGB proximity as an amenity. This is because (a) rural residential zoning has been extensively employed along the south Salem UGB, which encourages low density urban sprawl beyond the UGB, and (b) in their efforts to maintain conservancy zoning in rural North Saiem, policymakers may have to extend the urban South UGB into rural residential areas in order to accommodate development pressures. These various factors presently render difficult a conclusive analysis of urban containment influences on the urban South Salem land market. 


\section{CHAPTER 5}

\section{Conclusions and Policy Implications}

Urban containment programs are becoming an increasingly popular mode of controiiing spatial urban expansion throughout America. These programs typically contain urban development within delineated urban service limits or urban growth boundaries (UGBS). These programs also typically create greenbelts surrounding urbanizable areas. Greenbelts are created by acquisition of rural land either fee simple or its development rights, or by imposing conservancy regulations, such as exclusive farm use (EFU) zoning, on it. Whatever technique is employed, these programs typically intend to focus growth into urbanizable areas, eliminate speculation of rural land for nonrural uses, and preserve the benefits attributable to the availability of vast open spaces near urban areas.

Hitherto, theoretical and empirical efforts describing the effect of urban containment programs on urban-rural land behavior have been scant and generally inconclusive. Despite policymaker's explicit expectations of them, few urban containment programs are systematically evaluated for their ability to realize these expectations. This situation exists for want of an adequate theoretical and methodological basis by which to perform grounded evaluations. This dissertation set forth to provida pianning analysts with a theoretical and methodological basis by which to evaluate the influence of urban containment programs on urban-rural land behavior.

Developing a theory of program influences on land behavior requires borrowing from and unifying separate theories offered by the economic, geographic and planning disciplines. Such a unified theory 
is determined to consist of three basic components. First, based on traditional market segmentation and zoning literature, an urban containment program is intended to segment the urban-rural fringe land market into urban and rural components (Whitelaw, 1980). Market segmentation shou?d be detectable as a gap in the locus of 1 and values at the UGB; in turn, the gap should indicate that an excessive demand for urban land will have been created. Second, when a program includes a greenbelt program imposed on rural land then, according to Boal (1970) and Rosser (1978), rural land values should conform to Sinclair's (1967) peculiar convex land value gradient extending outward from the UGB. Such a gradient will indicate that the speculative value component of rural land has been removed and that the rural land market values land solely for its agricultural productivity. The gradient will be convex because, at some point beyond the UGB, agricultural land value will decline with decreasing distance from the UGB as urban externalities (such as trespassing and prohibitions against hours of operation, noise, dust, fertilizers, pesticides, etc.) increasingly inhibit agricultural productivity. Third, when programs create greenbelts beyond the UGB then, based largely on the hedonic literature, this researcher theorizes that the urban land market will value UGB proximity as an amenity. Taking these expectations together, the unified theory predicts that a properly devised urban containment program should affect urban-rural land values in the manner shown in Fig. 5.1.

The unified theory is operationalized by reduced form regression equations patterned after classical acessibility models of land value 


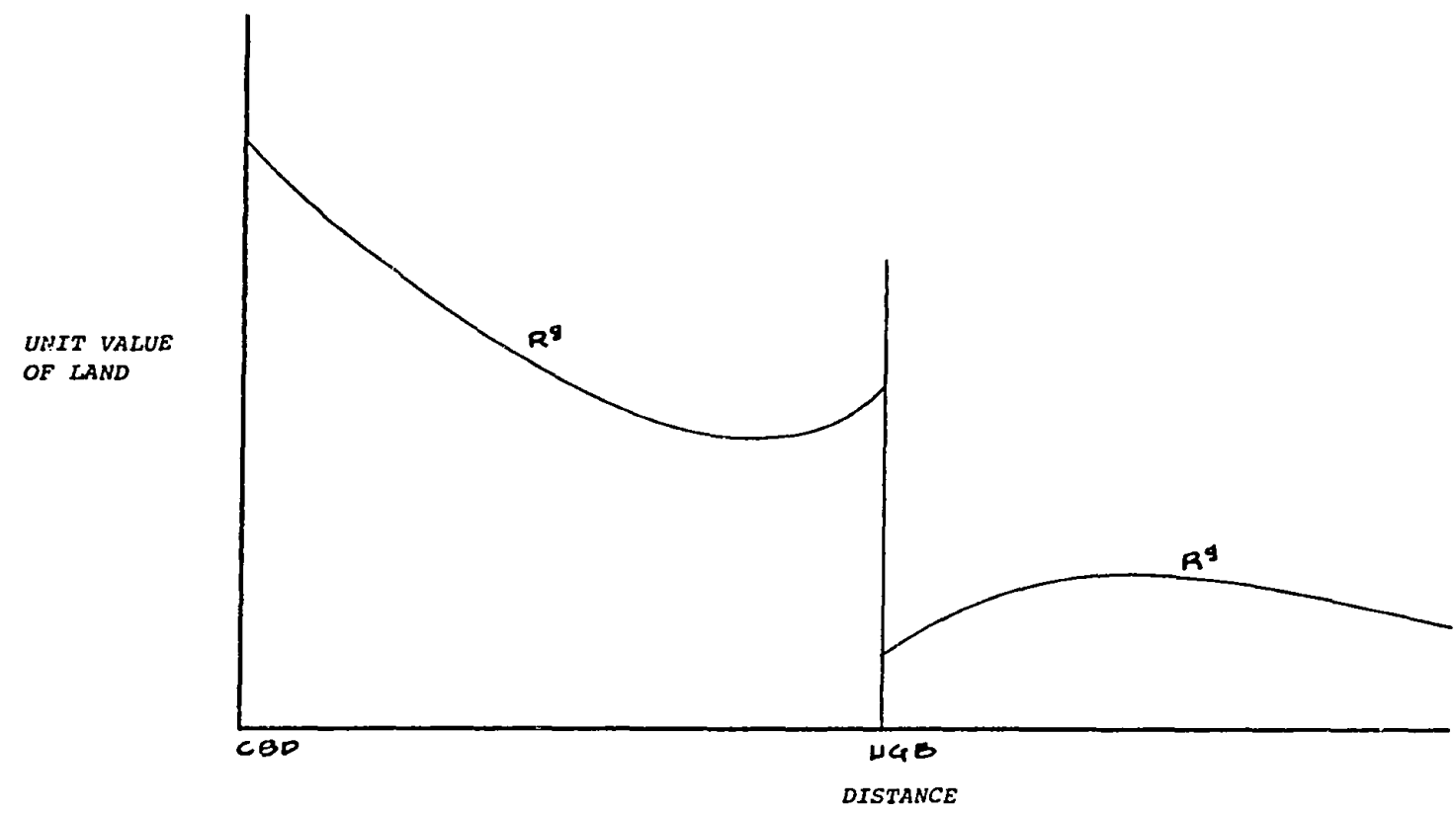

FIGURE 5.1: EFFECTS OF AIN URBAI CONTAIIMENT PROGRAM ON URBAIV-RURAL IAND VALUES.

When an urban containment program includes urban development incentives, conservancy zoning on rural 1and, and an urban growth boundary differentiating between urban and rural land uses, the urban-rural fringe land value gradient will appear as shown. 
theory; the equations are then applied to more than two hundred sales of vacant urban and rural land occuring during 1977-1979 in the Salem, Oregon, area. Results and implications following from this exercise are summarized according to the segmentation, rural submarket, and urban submarket components of the unified theory. Some policy questions are then addressed to Salem's policymakers. This dissertation concludes with a word on the generalizability of the unified theory and research approach undertaken here.

\section{A. URBAN-RURAL MARKET SEGMENTATION}

Based upon both a test of urban and rural price functions and performance of a UGB binary attribute, this research found that Salem's urban containment program appears to be associated the segmentation of its urban-rural land market into uniquely operating urban and rural submarkets. This finding counters Beaton, et al's. (1977) 1976 research, which concluded that no such association should be found in the near-term. In addition, this work found more conclusive segmentation evidence than that reported by Gleeson (1979), the only other relevant segmentation study available.

The differences between the impact of Salem's and Brooklyn Park's programs on urban-rural land behavior may be related to their structure. According to Gleeson (1979), Brooklyn Park's program includes an urban services limit and downzoning of rural land from one-third acre to five acre minimum parcel sizes for homesites. In addition, the City's affordable housing programs appear to have increased urban residential densities. Gleeson's evidence of market 
segmentation was limited to large acreage tracts, which provided landowners with more holding flexibility than offered by small tracts. The real influence of Salem's program appears to be on its control of rural land. All nonagricultural use proposals, including rural residential (RR) homes, require approval at a quasi-judicial tribunal; participants may appeal the tribunal's decision through the Land Use Board of Appeals to the Oregon Supreme Court. While owners of RR land are ustally able to gain approval for home construction and minor partitioning (into less than four lots), owners of EFU land are restricted from such activities unless they can prove that agricultural productivity will improve. In this regard, it was not surprising to find that Salem's program is also associated with segmentation of the rural submarket into RR and EFU categories.

The long-term effects of market segmentation on the quality of urban life and the pattern of urban development have not been seriously explored in literature, but some comments are worthy here. For example, the ability of urban containment programs to drive urban land prices up and thereby adversely affect the quality of urban life shouid not be dismissed. For example, Hall, et al. (1973), appear to lament the effectiveness of Britain's urban containment program:

... the biggest single failure of the (British) planning system is that it failed to check the rise in land prices, which has probably been the largest and most potent element of Britain's postwar inflation .... As well as encouraging higher densities, the price of 1 and has influenced both the nature and level of housing output .... The high level of house prices means that the proportion of the population who can afford to buy out of income a house which is in good condition and provided with what is generally regarded as acceptable standards of domestic facilities is probably as $10 \mathrm{w}$ as any period in Britain's history. (vol. 2, p. 294) 
They note this outcome despite Britain's extensive commitments to urban redevelopment, the construction of millions of subsidized housing units, and development of new and satellite towns. While low density rural development has been largely curbed, they note that government-authorized expansion into agricultural areas remains a predominant feature of urban development. Much like American analysts, British analysts have not reached any consensus on the nature of trade-offs incurred as a result of urban containment programs.

In the long-term, and perhaps despite its greenbelt preservation efforts, Salem's UGB may be forced to expand into the greenbelts. This research found that $R R$ zoned land enjoyed considerable price advantages over land subject to EFU zoning; an outcome which may influence the future pattern of urbanization. By restricting the supply of RR land, an excessive demand for RR land may be created and only the affluent may afford it. Such appears to be the case in rural South Salem - an area of gently rolling hills and pleasant views within roughly a fifteen minute commute from downtown Salem and the state capitol. Deprived of rural residential opportunities in the fertile agricultural area in rural North Salem, the RR market is focused into the South, and RR land prices rise so that only the affluent can enjoy the RR lifestyle. Based on Altshuler (1970), Morris \& Hess (1975), Hunter (1953) and Brager \& Specht (1973), one should expect rural South Salem to become an increasingly defined community of homogeneous socioeconomic and political orientations. What happens when Salem's UGB becomes filled-in and must be expanded? Will the affluent and perhaps influential rural residential South 
Salem community allow the city to "sprawl" into it? On the other hand, would not expanding the city's UGB into the agricultural district violate the premise of Salem's urban containment program? Inasmuch as Salem does not have a definitive UGB expansion policy, the issue is left to be resolved by another generation.

\section{B. RURAL SUBMARKET EFFECTS}

This research provides perhaps the first direct empirical evidence of Sinclair's theorized agricultural land value gradient. It also provides empirical support for the theorized conditions under which Sinclair's gradient may be observed, namely, the containment of urbanization within a stopline or UGB (Boal, 1970) and the removal of the speculative use value component of rural land by way of conservancy zoning (Rosser, 1978). Thus, it appears that Sinclair's gradient provides for an effective method of evaluating the success of an urban containment program. A program may be considered successful in removing speculative and nonagricultural use value of rural 1 and when Sinclair's gradient is found, as in the case of rural North Salem. Put another way, the failure of a program to preserve rural land strictly for agricultural uses may be evidenced by the traditional downward sloping land value gradient extending through the urban-rural fringe, as in the case of rural south Salem.

It is interesting to note that Salem's program apparently removed speculative use value of rural land without compensation. Britain's program, for example, was predicated on setting aside a three hundred million pound sterling fund to compensate rural landowners for the ir 
negotiated loss of specuiative use value. In addition, certain greenbelt programs in America (e.g., King County, Washington; Suffolk County, New York; Boulder, Colorado) involve either the outright purchase of land or the purchase of its development rights. It is remarkable, therefore, to find that Salem's program has apparently effected removal of speculative use value without giving consideration to equity issues (see, e.g., Hagman \& Misczynski).

The equity consideration should not be limited to speculative losses. This research indicates that agricultural land value is depressed by urban externalities when it is proximate to urban areas. Thus, it may be one thing to eliminate speculative use land value, but it may be quite another to avoid compensating greenbelt owners for losses strictly attributable to urban externalities.

Salem's policy documents appear to have deflected equity concerns by implying that areas subject to EFU zoning may be targeted for urbanization in the long term. Unlike Britain, Salem's program does not include the feature of directing "spillover" urbanization into a system of satellite towns. In fact, except for the Portland metropolitan area, Oregon's statewide program does not include a shared growth mechanism; all cities are required to contain the ir own growth and no city is allowed to plan for any more growth than its state-approved projections indicate. Thus, Salem's UGB may have to be expanded whenever the urban area becomes substantially filled-in. Such expansion may occur in EFU areas because owners of such 1 and will argue that (a) unlike rural residential areas which are difficult to assemble and develop because of ownership patterns and terrain, the 
large EFU tracts may be efficiently developed, (b) policy documents strongly suggest that short-term losses attributable to growth controls will be offset in the long run when the UGB is expanded, and (c) conservancy areas proximate to the UGB are already underproductive owing to urban externalities.

In the long term, if Salem continues to grow, then Sinclair's gradient may give way to the traditional downward sloping gradient as landowners speculate on the imminent expansion of the UGB. This situation is feasible because Salem's program does not result in the acquisition of rural land fee simple or its development rights; except for politically vulnerable land use controls, Salem does not enjoy the measure of greenbelt control that ownership of rights would provide. The emergence of a traditional downward sloping gradient may portend a period when greenbelt owners place economic and political pressure on decision makers to expand urbanization into greenbelts.

\section{URBAN SUBMARKET EFFECTS}

This research adds a dimension to the evaluation of urban containment programs not previously reported. While preyious research shows that the urban land market considers proximity to publicly owned greenbelts and open spaces as amenity, this research shows the conditions where such an amenity majy be detected if greentelt 1 and is privately owned. Some implications for policymakers emerge.

First, when a program includes both UGBs and conservancy zoning to create greenbelts, then the program may be deemed effective if the urban land market exhibits such confidence in the program that a 
greenbelt proximity amenity is obseryed, as in urban North Salem. Put another way, the failure of a program may be evidenced if the amenity is not detectable in that portion of the urban land market which is proximate to the UGB; this failure may be explained as the market's iack of confidence in the program's ability to contain urbanization and preserve greenbelts. In this regard, however, there are some interesting intermediate possibilities. For example, if landowners perceive that greenbelts will generate benefits to proximate urban land over a twenty or so year period, then the present value of that stream of benefits can be capitalized into the land. Over time, as UGB expansion becomes imminent, the present value of this stream of benefits declines. Alternatively, if policymakers should decide to renew their greenbelt commitment (e.g., by purchasing development rights), then this stream of benefits would be recapitalized.

Second, if a program effects creation of a greenbelt proximity amenity, then it may be viewed as giving a windfall to the benefiting urban land. Bidders who acquire land with a greenbelt proximity amenity can be expected to militate against public and private actions which threaten to dilute the amenity value, such as initiatives to expand the UGB or to allow greenbelt owners rural residential activities. In Oregon, these bidders enjoy especially favorable prospects for protecting their amenity, as Oregon's statewide planninis program consists of legal mechanisms designed to frustrate urbanization or low density rural residential development of greenbelts; This situation may create a combative relationship between owners of urban and greenbelt land; on the one hand, greenbelt 
owners are implicitly assured through policy statements that they can expect to enjoy windfalls when the city's UGB expands, but on the other hand, urban landowners can be expected to jealously defend their greenbelt proximity amenity. Fig. 5.1 illustrates the nature of this conflict. Salem's program has effected urban and rural land values in North Salem in the manner expected by the unified theory; a substantial proportion of rural land values have apparently been wiped out while urban land values have enjoyed a modest windfall.

\section{WINDFALLS FOR WIPEOUTS AND THE UTILITY OF THIS DISSERTATION}

Oregon does not have a mechanism for acquiring greenbelt rights or otherwise compensating greenbelt owners for losses associated with urban containment programs. In view of the considerations mentioned above, long-term preservation of greenbelts may not be assured if urban containment programs rely solely on politically vulnerable land use controls. What may the present generation of planners and decision makers do to ensure the long-term preservation of greenbelts?

One solution to this question may be to assess the windfalls accrued by benefiting urban landowners in order to acquire from greenbelt owners their development rights. If an average land value gradient is imagined to extend from the CBD outward through the rural countryside and superimposed on Fig. 5.1, then the value of 1 and above or below that line would become the basis for calculating both the windfall assessment and the approximate value of foregone development rights attributable to an urban containment program. Such an acquisition program has already been described theoretically and 
empirically (see, e.g., Correll, et al.) and it could help Salem ensure its long-term commitment to the preservation of greenbelts.

On the other hand, what are the consequences to efficient urban development under such an arrangement? As Salem grows, its program may provide some benefits which are not without certain costs to its residents such as smaller housing units, increased pollution, and decreased privacy. If greenbelt preservation (and a politically active rural South Salem community) prevents efficient development of large tracts coterminous with urban development, and considering that Oregon's statewide planning program does not allow for satellite development, how will Salem grow spatially? Perhaps Salem's implied intent to allow urbanization of greenbelts over time will enable the City to grow reasonably efficiently; urbanization of greenbelts, however, will not be without considerable political consequences.

Such policy considerations are logical extensions of properly executed evaluations of urban containment programs. However, this researcher notes concern that, while these programs are becoming increasingly relied upon to effect certain outcomes, comprehensive evaluations of them have not been performed hitherio. This researciser proposes that the theory and methodology developed in this dissertation provides the basis for evaluating any given urban containment program. In any event, this researcher implores analysts to improve and broaden their evaluation of American urban containment programs. 


\section{Selected Bibliography}

Adams, F. Girard, Grace Milgram, Edward W. Green, and Christine Mansfield, "Undeveloped Land Prices During Urbanization: A MicroEmpirical Study Over Time" in Review of Economics and Statistics, vol. 50, no. 2, pp. 248-258, 1968.

Alonso, Wiliiam, "A Theory of the Urban Land Market" in Papers and Proceedings of the Regiona! Science Association, vol. 6, 1950, pp. 149-157. See also excerpts under same title in Matthew Edel and Jerome Rothenberg, Readings in Urban Economics, MacMillan Co., New York, 1972, pp. 104-111,

Alonso, William, Location and Land Use, Harvard University Press, 1964.

Alonso, William, "A Reformulation of Classical Location Theory and its Relation to Rent Theory" in Papers and Proceedings of the Regional Science Association, vol. 19, pp. 23-44, 1967.

Altshuler, Alan, The Urban Transportation System: Policies and Policy Innovation, Joint Center for Urban Studies, M.I.T. and Harvard University, Cambridge, 1979.

Altshuler, Alan, Community Control, Pegasus, New York, 1970.

Archer, R.W., Policy and Research Issues in Subdivisions for Rural Residences, Hobby-Farms and Rural Retreats, 48th ANZAAS Congress, Melbourne, 1977.

Bahl, Roy W., "A Land Speculation Model: The Role of the Property Tax as a Constraint to Urban Sprawl" in Journal of Regional Science, vol. 8, no. 2, 1968.

Baumo l, W.J., Economic Theory and Operation Analysis Second ed., Prentice-Hall, Englewood Cliffs, 1965.

Beaton, C. Russe 11, Urban Growth Policies Paper No. 4: Costs of Urban Growth for the Salem, Oregon Area, Mid-Willamette Valley Council of Governments, Salem, 1972.

Beaton, C. Russe 11, James S. Hanson, and Thomas H. Hibbard, The Salem Area Urban Growth Boundary: Evaluation of Economic Impacts and Policy Recommendations for the Future, for Mid-Willamette Valley Council of Governments, Salem, 1977.

Becker, Gary S., The Economics of Discrimination, University of Chicago Press, Chicago, 1957.

Beriy, David, Ernest Leonardo and Kenneth Bieri, The Farmer's Response to Urbanization: A Study of the Middle AtTantic Region, Regional Science Research Institute, Unversity of Pennsyivania, Philadelphia, 1977. 
Berry, David and G. Steiker, "AnI Economic Analys is of Transfer of Development Rights", Natural Resources Journal, vol.17, pp.55-88, 1977.

Berry, David, Idling of Farmland in The Philadelphia Region, Regional Science Research Institute, Philadelphia, 1976.

Berry, David, "Effects of Urbanization on Agricultural Activities" in Growth and Change, vol. 9, no. 3, pp. 2-8, 1978.

Bish, Robert L. and Hugh 0. Nourse, Urban Economics and Policy Analysis, McGraw-Hill, New York, 1975.

Blomquist, Glenn and Lawrence Worley, "Hedonic Prices, Demands for Urban Housing Amenities, and Benefit Est imates" in Journal of Urban Economics, vol. 9, pp. 212-221, 1981.

Boal, Frederick W., "Urban Growth and Land Value Patterns: Government Influence" in The Professional Geographer, vol. XXII, No. 2, pp. 79$82,1970$.

Bourne, Larry S., Private Redevelopment of the Central City, Research Paper No. 112, Department of Geography, University of Chicago, 1967.

Bourne, Larry S., Private Redevelopment of the Central City, Research Paper No. 112, Department of Geography, University of Chicago, 1967.

Boyce, David E., Bruce Allen, Gene Desfor, and Richard Zuker, Impact of Rapid Transit on Suburban Residential Property Values and Land Development, Regional Science Research Institute, Philadelphia, 1972.

Brager, George and Harry Specht, Community Organizing, Columbia University Press, New York, 1973.

Brigham, Eugene F., "The Determinants of Residential Land Value" in Land Economics, vol. 41, no. 4, pp. 325-334, 1965.

Brookshire, David S., Mark A. Thayer, William D. Schulze, and Ralph d'Arge, "Valuing Public Goods: A Comparison Survey of Hedonic Approalites" in The Amiterican Economie Review, vol. 72, no. 1, pp. 165$177,1980$.

Brown, Gardner M. and Henry 0. Pollakowski, "Economic Valuation of Shoreline" in Review of Economics and Statistics, vol. 59, no. 3, pp. 272-278, 1977.

Bryant, William R. and Howard E. Conkling, "New Farmland Preservation Programs in New York" in Journal of the American Institute of Planners, American Institute of Planners, Washington, D.C., Vol. 41, pp. 390-396, 1975.

Bureau of Governmental Research and Service, Local Government Policies for Urban Development, University of Oregon, Eugene, 1974. 
Burchell, Robert W., Planned Unit Development: New Communities American Style, Rutgers, Center for Urban Policy Research, New Brunswick, N.J., 1972.

Burgess, Ernest W., "The Growth of the City" in The City, ed by R.E. Park, E.W. Burgess, and R.D. McKenzie, University of Chicago Press, Chicago, 1925.

Burgess, Ernest W., "Urban Area" in Chicago, an Experiment in Social Science Research, ed. by T.V. Smith and Leonard D. White, University of Chicago Press, 1929.

Butler, Richard V., "The Specification of Hedonic Indexes for Urban Housing" in Land Economics, vol. 58, no. 1, pp. 96-108, 1982.

Carter, Steve, Kendall Bert, and Peter Nobert, Local Government Techniques for Managing Growth, Management Information Service Report Vol. 6, No. 5, 1974.

Castle, E., "The Market Mechanism, Externalities, and Larid Economics" in Journal of Farm Economics, vol. 47, pp. 542-557, 1965.

Chapin, F. Stuart, Jr. and Edward J. Kaiser, Urban Land Use Planning, third ed., University of Illinois Press, Urbana, 1979.

Chicoine, David L., "Farmland Values at the Urban Fringe: An Analysis of Sales Prices" in Land Economics, vol. 57, no. 3, pp. 353-362, 1981.

Ciriacy-Wantrup, S.V., Resource Conservation: Economics and Policies, Third ed., llniversity of California Press, Berkeley: 1968.

Clawson, Marion, Suburban Land Conversion in the United States, The Johns Hopkins Press, Baltimore, 1971.

Clawson, Marion, and Harvey S. Perloff, "Urban Land Policy:

Alternatives for the Future" in Management and Control of Growth, Vol. 3, ed. by Randall W. Scott, David J. Brower and Dallas D. Miner, Urban Land Institute, Washington, D.C., pp. 8-21, 1975.

Clawson, Marion, "Urban Sprawl and Speculation in Suburban Land" in Land Economics, pp. 99-111, May, 1962.

Clonts, Howard A., Jr., "Influences of Urbanization on Land Values at the Urban Periphery", Land Economics, vol.46, no.4, pp. 489-491, 1970.

Colwell, Peter F. and C.F. Sirmans, "Area, Time, Centrality and the Value of Urban Land", Land Economics, vol.54, no.4, pp. 514-519, 1978.

Correl1, Mark A., Jane H. Lillydah1, Larry D. Singel1, "The Effects of Greenbelts on Residential Property Values: Some Findings on the Political Economy of Open Space" in Land Economics, vol. 54, pp. 207-217, 1978. 
Costonis, John J., "Development Rights Transfer: Easing the PolicePower, Eminent Domain Deadlock" in Zoning Digest, vol. 26, p. 6, American Society of Planning Officials, Chicago, 1974.

Coughlin, Robert E. and Thomas Plaut, "Less-than-fee Acquisition for the Preservation of Open Space: Does It Work?" in Journal of the American Institute of Planners, American Institute of Planning, Washington, D.C., vol. 44, pp. 452-462, 1978.

Coughlin, Robert E., et al, Saving the Garden: The Preservation of Farmland and Other Environmentally Valuable Land, Regional Science Research Institute, University of Pennsylvania, Philadelphia, 1977.

Coughlin, Robert E. and Tatsuhiko Kawashima, Property Values and Open Space in Northwest Philadelphia: An Empirical Analys is, Regional Science Reseach Institute, Discussion Paper No. 64, 1973.

Crecine, John P., Otto A. Davis and John E. Jackson, "Urban Property Markets: Some Empirical Results and Their Implications for Municipal Zoning" in Journal of Law and Economics, vol. 10, pp. 79-99, 1967.

Davis, Otto A., "Economic Elements in Municipal Zoning Decisions" in Land Economics vol. 39, November, 1963.

DeLacy, P. Barton, "Cash Value Equivalency in Residential Appraising" in Appraisal Journal, vol. 51, no. 1, pp. 81-88, 1983.

Department of Land Conservation and Development, Common Questions About Statewide Planning Goals, Salem, 1976.

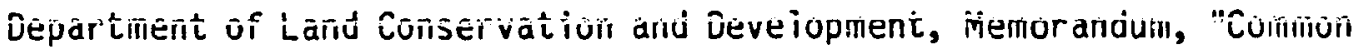
Questions on Urban Development Paper", Salem, November, 1979.

Department of Land Conservation and Deve?opment, Memorandum, "UGB Area and Joint Management Agreement Position Paper", Salem, February, 1979.

Diamond, Douglas B., Jr., "The Relationship Between Amenities and Urban Land Prices" in Land Economics, vol. 56, pp. 21-32, 1980.

Downing, Paul B., "Estimating Residential Land Value by Multivariate Analysis" in The Assessment of Land Value: Proceedings of a Symposium Sponsored by the Committee on Taxation, Resources and Economic Development, ed. by D.M. Holland, TRED Publication No. 5, University of Wisconsin Press, Madison and London, pp. 101-123, 1970.

Downing, Paul B., "Factors Affecting Commercial Land Value: An Empirical Siudy of Milwaukee, Wiscons in" in Land Economics, vol. 49, no. 1 , pp.44-56, 1973.

Dueker, Kenneth J., Irwin P. Levin, James G. Strathman, and Alan G. Phipps, Residentian Choice on the Urban Fringe, Final Report No. 24, Institute of Urban and Regional Research, University of Iowa, Ames, 1980. 
Dueker, Kenneth J., Irwin P. Levin, James G. Strathman, and Alan G. Phipps, "Rural Residential Development Within Metropolitan Area", School of Urban Affairs, Portland State University, Portland, 1981.

Dunford, Richard W., "Evaluating Alternative Compensation and Recapture Techniques for Expanded Public Control of Land Use" in Natural Resources Journal, vol. 19, pp. 21-41, 1979.

Einsweiler, Robert C., Michael E. Gleeson, Ian Traquair, Alan Morris and Diane Sprague, Urban Growth Management Systems, Planning Advisory Service, Report Nos. 309, 310, American Society of Planning Officials, Chicago, 1975a, see all under same title in Management and Control of Growth, Randall W. Scott, David J. Brower, Dallas D. Miner, eds., Urban Land Institute, Washington, D.C., 1975b.

Ely, R.T. and G.S. Wehrwe in, Land Economics, McMillan, New York, 1940.

Epp, Donald J. and K.S. Al-Ani, "The Effects of Water Quality on Rural Nonfarm Residential Property Values" in American Journal of

Agricultural Economics, vol. 61, pp. 529-534, 1979.

Fishman, Richard P. and Robert D. Gross, "Public Land Banking: A New Praxis for Urban Growth" in 23 Case Western Law Review 897, 1972.

Freeman, A. Myrick, III, "Hedonic Prices, Property Values and Measuring Environmental Benefits: A Survey of the Issues" in Scandinavian Journal of Economics, vol. 81, pp. 154-173, 1979.

Freilich, Robert H., "Development Timing, Moratoria, and Controlling Growth " in Management and Control of Growth, Randall W. Scott, David J. Brower, and Dallas D. Miner, eds., Urban Land Institute, Washington, D.C., 1975.

Furuseth, Owen J., "The Oregon Agricultural Protection Program: A Review and Assessment" in Natural Resources Journal, vol. 20, pp. 603$614,1980$.

Furuseth, Owen J., "Update on Oregon's Agricultural Protection Program: A Land Use Perspective" in Natural Resources Journal, vol. 21, pp. 57-70, 1981.

Gaffney, M., "Containment Policies for Urban Sprawl" in R. Stauber, ed., Approaches to the Study of Urbanization, Governmental Research Series No. 27, University of Kansas, Lawrence, 1964.

Gardner, B. Delworth, "Review of Trends in Land Use and Competition for Land to Produce Food and Fiber" in Perspectives on Prime Land, U.S. Department of Agriculture, USGPO, Washington, D.C., 1975.

Gemache, Adrian, Land Use Regulation in Oregon: An Evaluation, (Discussion Draft), Land Use Study Group, Portland, 1981. 
Gibson, James A., "On the Allocation of Prime Agricultural Land Preservation" in American Journal of Agricultural Economics, vol. 59, no. 5, pp. 1027-1036, 1977.

Gleeson, Michael E., "Effects of an Urban Growth Management System on Land Values" in Land Economics, vol. 55, no. 3, pp. 350-365, 1979.

Goldberg, Michael A., "Residential Developer Behavior: Some Empirical Findings" in Land Economics, vol. 50, no. 1, pp. 85-89, 1974.

Goldberg, Michael A. and Daniel D. Ulinder, "Residential Developer Behavior 1975" in Land Economics, vol. 52, no. 3, pp. 363-370, 1976.

Gottman, Jean, Megalopolis, The 20th Century Fund, New York, 1961.

Grether, D.M. and Peter Mieszkowski, "Determinants of Real Estate Values" in Journal of Urban Economics, vol. 1, no. 2, pp. 127-145, 1974.

Gustafson, Greg C, Thomas L. Daniels, and Rosalyn P. Shirack, "The Oregon Land Use Act:Implications for Farmland and Open Space Protection", Journal of the American Planning Association, vol. 48, no. 3, 1982.

Hagman, Donald and D. Misczynski, eds., Windfalls for Wipeouts American Society of Planning Officials, Chicago, 1978.

Haig, Robert M., "Toward an Understanding of the Metropolis" in Quarterly Journal of Economics, vol. XL, pp. 179-208, 1929.

Hal1, Peter, Ray Thomas, Harry Gracey, and Roy Drewett, The Containment of Urban England, two volumes, Sage, Beverly Hills, 1973.

Halprin, Lawrence \& Associates, Willamette Valley: Choices for the Future, Executive Department, State of Oregon, Salem, October 1972.

Hammer, Thomas R., Edward T. Horn, Robert E. Coughlin, The Effect of a Large Urban Park on Real Estate Value, Regional Science Research Institute, Philadelphia, 1971.

Hanson, David E. and S.I. Schwartz, "Landowner Behvaior at the RuralUrban Fringe in Response to Preferential Property Taxation" in Land Economics, vol. 51, no. 4, pp 341-354, 1976.

Hanson, John A., "Evaluation of Speculative Land Developments in Natural Resources Areas" unpub. mss., Portland State University, School of Urban and Public Affairs, Portland, 1976.

Harris, Chauncey D. and Edward L. Ullman, "The Nature of Cities", Annals of the American Academy of Political and Social Science, vol. 242, pp. 7-17, 1945.

Harrison, Bennett, Urban Economic Development, The Urban Institute, Washington, D.C., 1978. 
Harvey, Robert 0. and W.A.V. Clark, "The Nature and Economics of Urban Sprawl" in Land Economics, vol. 41, no. 1, 1965.

Hirsch, Werner Z., "The Efficiency of Restrictive Land-Use Restrictions" in Land Economics, vol. 53, no. 2, pp. 145-156, 1977.

Hirst, Joanna and Thomson Hirst, "Capital Facilities Programming As A Growth Control Tool" in Management and Control of Growth, Randall W. Scott, David J. Brower, Dallas D. Miner, eds., Urban Land Institute, Washington, D.C., 1975.

Howard, Ehenezer, Garden Cities of To-morrow, MIT Press, Cambridge, 1965 (orig. pub. 1902).

Hoyt, Homer, The Structure and Growth of Residential Neighborhoods in American Cities, Federal Housing Administration, Washington, D.C., 1939.

Hunter, Floyd, Community Power Structure, University of North Carolina Press, Chapel Hi11, 1953.

Hurd, Richard M., Principles of City Land Values, The Record and Guide, New York, 1903.

Hushak, Leroy J., "The Urban Demand for Urban-Rural Fringe Land" in Land Economics, vol. 51, pp. 112-123, 1975.

Hushak, Leroy J. and Kazem Sadr, "A Spatial Model of Land Market Behavior",American Journal of Agricultural Economics, pp.697-702, 1979.

Isberg, Gunnar, "Controlling Growth in the Urban Fringe" in Management and Control of Growth, Randall W. Scott, David J. Brower and Dallas D. Miner, eds., Urban Land Institute, Washington, D.C., 1975.

Jeffrey, Leonard H., Managing Oregon's Growth: The Politics of Development Planning, Conservation Foundation, Washington, D.C., 1983.

Kain, John F., Urban Form and the Costs of Urban Services, Program on Regional and Urban Economics, Harvard University, Cambridge, 1966.

Kain, John F. and John M. Quigley, "Measuring the Value of Housing Quality" in Journal of the American Statistics Association, vol. 65, pp. $532-548,1970$.

Kaiser, Edward J., et al, "Predicting the Behavior of Predevelopment Land Owners on the Urban Fringe" in Journal of the American Institute of Planners, vol. 34, pp. 328-333, 1968.

Kaplan, Marshall, Implementation of the Baltimore Regional Plan Alternative, Regional Planning Council, Battimore, 1965. 
Klein, John V. N., "Preserving Farmland on Long Island" in Management and Control of Growth, vol. 4, ed. Frank Schneidman, Jane A. Silverman, and Rufus C. Young, Jr., The Urban Land Institute, Washington, D.C., 1978.

Lafferty, Ronald N. and H.E. Frech, III, "Community Environment and the Market Value of Single-Family Homes: The Effect of the Dispersion of Land Uses" in The Journal of Law and Economics, vol. 21, no. 2, pp. 381-394, 1978.

Land Conservation and Development Commission, Statewide Planning Goals and Guidelines, Salem, December, 1974.

Lessinger, Jack, "Exclusive Agricultural Zoning - An Appraisal" in Land Economics, vol. 34, Nos. 2 and 3, May and August, 1958.

Lessinger, Jack, "The Case for Scatteration: Some Reflections on the National Capital Regional Plan for the Year 2000" in Journal of the American Institute of Planners, vol. 28, No. 3, Augus 1962.

Li, Mingche and H. James Brown, "Micro-Neighborhood Externalities and Hedonic Housing Prices", Land Economics, vol.56, no.2, pp.125-141, 1980.

Libby, Lawrence W., "Land Use Policy: Implications for Commercial Agriculture" in American Journal of Agricultural Economics, vol. 56, pp. 1143-1152, 1974 .

Lowenstein, Louis K., ed., Urban Studies MacMillan, New York, 1971.

Mandelker, Daniel R., Greenbelts and Urban Growth, University of Wisconsin Press, Madison, 1962.

Maser, Steven M., "The Effects of Zoning and Externalities on the Price of Land: An Empirical Analys is of Monroe County, New York" in The Journal of Law and Economics; vol. 20, no. 2, pp. 111-132, 1977.

Mattingly, Paul F., "Intensity of Agricultural Land Use Near Cities: A Case Study", The Professional Geographer, vol.XXIV, no.1, pp.7-10, 1972.

McDougall, G.S., "Local Public Goods and Residential Property Values: Some Insights and Extensions" in National Tax Journal, vol. 29, pp. $436-447,1976$.

Mid-Willamette Valley Council of Governments, An Urban Growth Policy for the Salem, Oregon Area, Salem, June 1971, revised December, 1974.

Mid-Willamette Valley Council of Governments, Papers and Discussion Outlines, Report No. 1, Salem, Jan., 1972.

Mid-Willamette Valley Council of Governments, Combining Public Regulation and Finlic Compensation to Guide Urban Growth, Report No. 2. Salem, Marcii, 1972. 
Mid-Willamette Valley Council of Governments, Developmental Effects of an Urban Growth Boundary on the Salem, Oregon Area, Report No. 5, SaTem, JuTy, 1972.

Mills, Edwin S., Urban Economics, Scott-Foresman \& Co., Glenview, Ill. 1972.

Mills, Edwin S., "The Value of Urban Land" in The Quality of Urban Environment, ed. by Harvey Perloff, Johns Hopkins Resources for the Future, Baltimore, 1969.

Mishan, E.J., "The Relationship Between Joint Products, Collective Goods, and External Effects" in Journal of Political Economics, vol. 77, pp. 329-348, 1969.

Morris, David and Karl Hess, Neighborhood Power, Beacon, Boston, 1975. Mumford, Lewis, The Culture of Cities, Harcourt, Brace \& Co., New York, 1939.

Mumford, Lewis, "The Social Function of Open Spaces" in Landscape, Vol. 10, No. 2, 1960-61.

Muth, Richard, "Economic Change and Rural-Urban Land Conversions" in Econometrica, vol. 29, pp. 1-23, 1961.

Much, Richard, Cities and Housing, University of Chicago Press, Chicago, 1969.

National Academy of Sciences, National Academy of Engineering, Urban Growth and Land Development: The Land Conversion Process report of the Land Use Subcommittee of the Advisory Committee to the Department of Housing and Urban Development, Washington, D.C., USGPO, 1972.

National Agricultural Lands Study, The Protection of Farmland: A Reference Guidebook for State and Local Governments, Washington, D.C., 1981.

Nelson, A. C., "Comment On 'The Oregon Limi Use Act: Implications for Farmland and Open Space Preservation ", Journal of the American Planning Association, Chicago, vo 1.49, no. 1, pp. 85-87, 1983a.

Nelson, A.C., Comment in Natural Resources Journal, vol. 23, no. 1 , pp. 1-5, 1983b.

Nelson, J. P., Economic Analysis of Transportation Noise Abatement, Harvard University Press, Cambridge, 1978.

Niedercorn, J.H., "A Negative Exponential Model of Urban Land Use Densities and Its Implications for Metropolitan Development" in Journal of Regional Science, vol. 11, pp. 317-26, 1971. 
Northan, R.M., "Vacant Urban Laîu in the Ainerican City" in Land Economics, vol. 47, 1971.

Oats, Wallace E., "The Effects of Property Taxes and Local Public Spending on Property Values: A Comment and Further Results" in Journal of Political Economy, vol. 81, pp. 1004-1008, 1973.

1000 Friends of Oregon, Administration of Exclusive Farm Lands in Twelve Oregon Counties: A Case Study of County Application of State Standards to Protect Oregon Farmland, Portland, 1981.

Ohls, James C., Richard Chadbourn Weisberg, Michelle J. White, "The Effect of Zoning on Land Value" in Journal of Urban Economics, vol. 1, no. 4, pp. 428-444, 1974.

Ohls, James C., Richard Chadbourn Weisberg, Michelle J. White, "Welfare Effects in Alternative Models of Zoning" in Journal of Urban Economics, vol. 3, no. 1, pp. 95-96, 1976.

Oregon Revised Statutes, Chapters 92, 197, 215, 380; 1974.

Osborn, Frederick J. and Arnold Whittick, The New Towns: The Answer to Megalopolis, McGraw-Hill, New York, 1946.

Pasour, E.C., "The Capitalization of Real Property Taxes Levied on Farm Real Estate" in American Journal of Agricultural Economics, vol. 52, pp. 549-556, 1972 .

Plaut, Thomas, The Effects of Urbanization on the Loss of Farmiand at the Urban Rural Fringe: A National and Regional Perspective Discussion Paper No. 94, Regional Science Research Institute, University of Pennsylvania, Philadelphia, 1976.

Pollakowski, Henry 0., "The Effects of Property Taxes and Local Public Spending on Property Values: A Comment and Further Results" in Journal of Political Economy, vol. 81, pp. 994-1003, 1973.

Ratcliff, Richard U., "The Dynamics of Efficiency in the Locational Distribution of Urban Activities", reprinted in Readings in Urban Geography, eds. H.M. Mayer and C.F. Kohn, University of Chicago Press, Chicago, 1959.

Ratcliff, Richard U., Urban Land Economics, McGraw-Hil1, New York, 1949.

Real Estate Research Corporation, The Costs of Sprawl, Council on Environmental Quality, Dept. of Housing and Urban Development, Environmental Protection Agency, Washington, D.C., USGPO, 1974a.

Real Estate Research Corporation, The Costs of Sprawl: Literature Review, Council on Environmental Quality, Dept. of Housing and Urban Development, Environmental Protection Agency, Washington, D.C., USGPO, $1974 b$. 
Regional Science Research Institute, Untaxing Open Space: An

Evaluation of the Effectiveness of Differential Assessment of Farms and Open Space, Council on Environmental Quality, Washington, D.C., USGPO, Apri 1, 1976.

Reuter, Frederick H., "Externalities in Urban Property Markets: An Empirical Test of the Zoning Ordinance of Pittsburgh", Journal of Law and Economics, vol. 16, pp. 313-349, 1973.

Richardson, Harry W., Joan Vipond, and R.A. Furbey, "Land Prices in Edinburgh: 1952-1967" in Scottish Journal of Political Economy, yol. $2 i$, no.1, pp. 67-75, 1974 .

Ridker, Ronald G. and John A. Henning, "The Determinants of Residential Property Values With Special Reference to Air Pollution" in Review of Economics and Statistics, vol.49, no.2, pp.246-257, 1967.

Rogers, William R., A Model for Rating Agricultural Suitability of Land Parcels in Western Oregon, master thesis, Soil Science Department, Oregon State University, June, 1980.

Rosen, Sherwin, "Hedonic Prices and Implicit Markets: Product Differentiation in Pure Competition" in Journal of Political Economy, vol. 82, pp. 34-55, 1974.

Resser, J. Barkley, Jr., "The Theory and Policy Implications of Spatial Discontinuities in Land Values" in Land Economics, vol.54, no. 4, pp. 430-441, 1978.

Samuelson, Paul A., "The Pure Theory of Public Expenditures" in Review of Economics and Statistics, vol. 36, pp. 387-398, 1954.

Schmid, A. Allan, Converting Rural Land to Urban Uses, Johns Hopk ins, Baltimore, 1968.

Schnare, Ann B. and Raymond Struyk, Jr., "Segmentation in Urban Housing Markets" in Journal of Urban Economics, 1976.

Shoup, Donald C., "The Optimal Timing of Urban Land Development" in Papers and Proceedings of the Regional Science Association, vol. 25, pp. 33-44, 1970 .

Sinclair, Robert, "von Thunen and Urban Sprawl" in Annals of the Association of American Geographers, vol. 57, pp. 72-87, 1967.

Smith, Barton A., "Measuring the Value of Urban Amenities" in Journal of Urban Economics, vol. 5, no. 3, pp. 370-387, 1978.

Smith, Halbert C., Carl J. Tschappat and Ronald L. Racster, Real Estate and Urban Development, Irwin; Homewood, I11., 1977. 
Soil Conservation Society of America, Land Use: Tough Choices in Today's World. Special Publication No. 22, Ankeny, Iowa, 1977.

Strong, Ann Louise, Open Space in the Penjerdel Region: Now or Never, Penjerdel, Philadelphia, 1963.

Sullivan, Edward J., "The Greening of the Taxpayer: The Relationship of Farm Zone Taxation in Oregon Land to Land Use" in Willamette Law Journal, Vol. 9, pp 1-25, 1975.

Toulan, Nohad A., Public and Private Costs of Open Space Preservation, dissertation, University of Pennsylvania, Graduate School of Arts and Sciences, Philadelphia, 1965.

U.S. Bureau of the Census, U.S. Census of Population: 1970, "Number of Inhabitants", Final Report PC(1)-Al, United States Summary (Washington, D.C., USGP0, 1971).

U.S. Bureau of the Census, U.S. Census of Population: 1980: "Oregon Summary" (Washington, D.C., USGPO, 1981).

Von Thuenen, J.H., Isolated State. An English Edition of Der Isolierte Staat, trans. by Carla M. Wartenberg, 1966, orig. 1826.

Weicher, John C. and Robert H. Zerbst, "The Externalities of Neighborhood Parks: An Empirical Investigation" in Land Economics, vol. 49, pp. 99-105, 1973.

Whitelaw, W. Ed., "Measuring the Effects of Public Policies on the Price of Urban Land" in Urban Land Markets: Price Indices, Supply Measures, and Public Policy Effects, ed. byt J. Thomas Black and James E. Hoben, ULI Research Report No. 30, Urban Land Institue, Washington, D.C., 1980.

Wieand, Kenneth, Jr. and Richard F. Muth, "A Note on the Variation of Land Values With Distance From the CBD in St. Louis" in Journal of Regional Science, vol. 12, no. 3, pp. 469-473, 1972.

Willamette Basin Task Force, Willamette Basin, Comprehensive Study, Pacific Northwest River Basins Commission, 1969.

Witte, Anr D. and Sharon K. Long, "Evaluating the Effects of Public Policies on Land Prices in Metropolitan Areas: Some Suggested Approaches" in Urban Land Markets: Price Indices, Supply Measures, and Public Policy Effects, ed. by J. Thomas Black and James E. Hoben, ULI Research Report No. 30, Urban Land Institute, Washington, D.C., 1980 
APPENDIX

SUPPLEMENTAL INFORIATION

This appendix includes (a) chow tests and related regression results for all cases, rural cases, and urban cases, (b) means and standard deviations of the attributes of specific regressions reported in the text, (c) correlation matrices of specific ragressions reported in the tex, (d) casewise plots of standardized residuals by increasing DCBD scores of specific regressions reported in the text, and (e) alternative regressions of models otherwise reported in the text using the semi-log functional form.

Some information presented in the text has different nomenclature than found in the appendix, namely (a) appendix significant $t$ levels are tivo tailed while the text converts them to one tail levels, and (b) title of some attributes are different: RR in the text means NONEFU here, DUGB in the text means eitiner DWUGB or DBUGB here, depending on whether the regression is of urban or rural cases respectively, and SERVICES in the text means UTILITYS here. 
CHOW TESTS

1. All cases, urban cases, rural cases. Model:

PACRE $=f($ SIZE, TIME, SOILS, INCOME, TERMS , TAX, UTILITYS, EFU, DCBD $)$

$F=\frac{\left(1.69463(10)^{9}-7.14088(10)^{15} / 10\right.}{7.14088(10)^{15} / 187}=18.70$

2. All rural cases measured to UGB, Rural North cases, Rural South cases. Model:

PACRE $=f($ SIZE, TIME , SCILS, INCOME, TERMS , TAX, EFU, DCBD, DUGB, DUGB2 $)$

$F=\frac{\left(4.00399(10)^{8}-8.52488(10)^{15} / 11\right.}{8.52488(10)^{15} / 71}=6.45$

3. All urban cases, Urban North cases, Urban South cases. Model: PACRE $=$ F(SIZE, TIME, SOILS, INCOME, TERMS, TAX, UTILITYS, DCBD, DUGB, OUGB2)

$$
F=\frac{\left(6.37582(10)^{8}-1.62216(10)^{16} / 11\right.}{1.62216(10)^{16 / 62}}=5.64
$$

Chow Test Procedure:

$F=\frac{(\text { RRSS }- \text { URSS }) / k+1}{\left(U R S S / n_{1}+n_{2}-2 k-2\right)}$ 
Chow Test Regressions: $\triangle 11$ Cases.

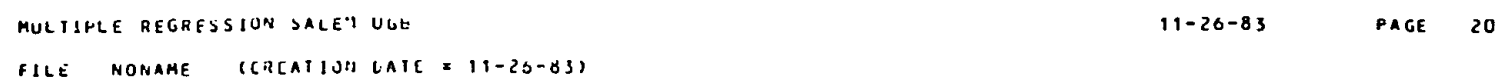

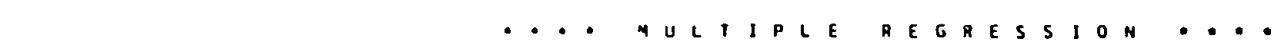

ELUAiJun number a.

Dependent variahle.. Pacre

Beginning block number 1. methoo: enter

VARIAGLE(S) ENTERED ON STEP NUTAER

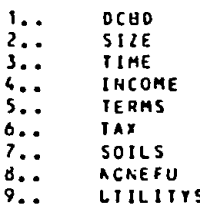

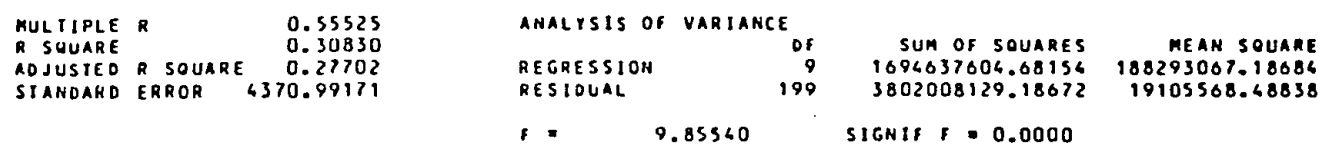

$\Rightarrow 9.85560$ SIGNis: $=0.0000$

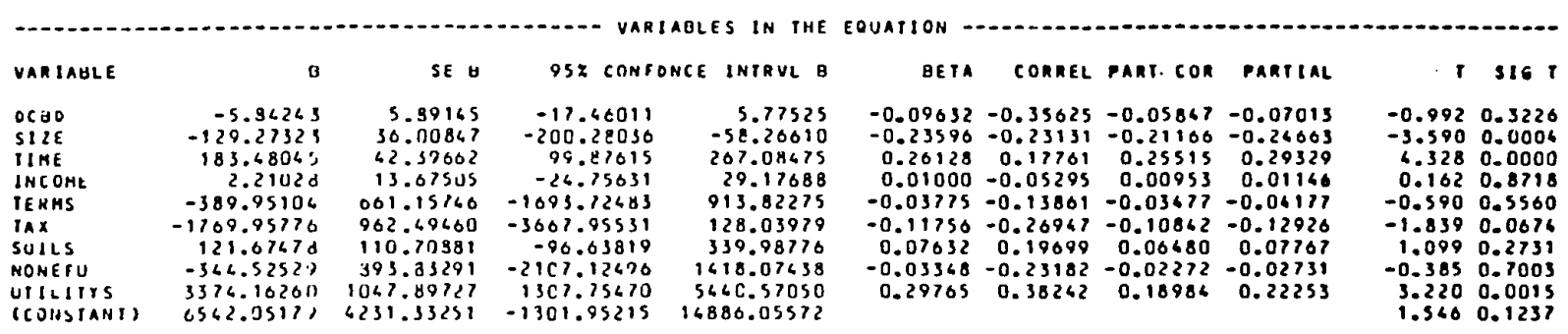

for uluck number I thl reouested vartagles entereo. 
Urban Cases

multiple negnession salen ugB

11-28-83 PAGE 14

GILE homake (CREATION OATE = 11-28-83)

$$
\text { ... MUL I }
$$

Govation MUMEe: 2 .

(t)

PACRE

SIZE

oependent variable.. packe

the sollovimg, 1 variazles ane constants or have missing

geginhing alock munaen 1. methon: enten

VARIAELE (S) ENTEREO ON STEP MUMBER

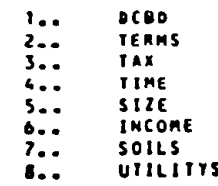

SOILS

INCOME

TERMS

TAX

TAX ILITYS

NONEFU

DHUGB

DOUGB.

8.. villitrs

DBUGBZ

$\begin{array}{rr} & 11-28-83 \\ \text { MEAN } & \text { STO DEV } \\ 11036.033 & 5402.185 \\ 8.122 & 10.192 \\ 9.799 & 7.360 \\ 16.791 & 3.471 \\ 212.093 & 28.356 \\ 0.430 & 0.498 \\ 0.035 & 0.185 \\ 0.698 & 0.662 \\ 0.0 & 0.4 \\ 226.953 & 45.435 \\ 39.733 & 31.703 \\ 2572.081 & 4053.169 \\ 0 . & 0 . \\ 0 . & 0 .\end{array}$

$\begin{array}{ll}\text { MULIIPLE } & 0.50612 \\ \text { a SOUARE } & 0.25613\end{array}$

AMALTSIS OF VARTANCE

\begin{tabular}{l} 
ADJUSIED R SQUARE 00.17664 \\
SIAMDARO ERROR \\
\hline
\end{tabular}

aEgaEsSIOH
aESIOUAL

of
77

SUN Of SQUaties

MEAN SOUARE

F $3.27963 \quad 516$ NIF $=0.0029$

78800292.16508
26028630.56329

\begin{tabular}{|c|c|c|c|c|}
\hline VARIABLE & $:$ & SE $B$ & OE IA & $1516^{8}$ \\
\hline $\begin{array}{l}\text { OCBD } \\
\text { IERMS } \\
\text { IAX } \\
\text { IINE } \\
\text { SIIE } \\
\text { INCOME } \\
\text { SOILS } \\
\text { UIILITYS } \\
\text { ICONSIANIS }\end{array}$ & 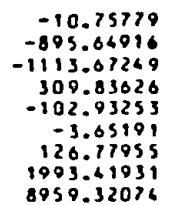 & $\begin{array}{r}20.60096 \\
1209.68127 \\
3056.76003 \\
78.82720 \\
06.35893 \\
23.89532 \\
195.86781 \\
1955.85686 \\
8198.36638\end{array}$ & $\begin{array}{l}-0.09068 \\
-0.08257 \\
-0.03205 \\
0.02212 \\
-0.19620 \\
-0.01817 \\
0.08140 \\
0.17066\end{array}$ & 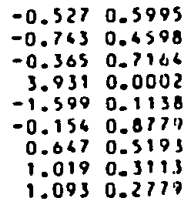 \\
\hline
\end{tabular}

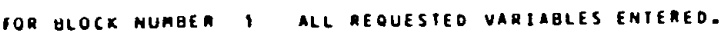


Rural Cascs

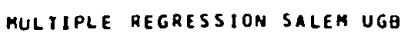

$11-28-83$

FILE NONAME (CREAIION DATE $=11-28-83)$

$$
\text { ... nultiple aegression.... }
$$

EGUABion nUmber 2.

DEPENDENT VARTAGLE.. PACRE

THE folloning I variables are constants cr have hissing correlations ano can nOt

UIILITYS

Beginning block number 1. method: entea

VARIAGLE(S) EMIERED ON STEP NUMBER

$$
\begin{aligned}
& \begin{array}{l}
1 . . \quad \text { DCBO } \\
2 . . \quad \text { JnCONE }
\end{array} \\
& \text { 3.: TIME } \\
& \text { 5.. IAX }
\end{aligned}
$$

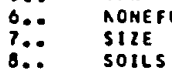

\section{RULTIPLE R $\quad 0.67392$}

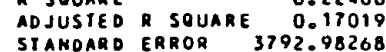

\begin{tabular}{|c|c|c|c|c|}
\hline VARIAGLE & a & SE 8 & BETA & 5167 \\
\hline $\begin{array}{l}\text { OCHO } \\
\text { INCONE } \\
\text { IINE } \\
\text { IERAS } \\
\text { IAX } \\
\text { TONEFU } \\
\text { SIILE } \\
\text { SOILLS } \\
\text { (CONSTANT) }\end{array}$ & $\begin{array}{r}0.95968 \\
15.36701 \\
72.07707 \\
-673.21279 \\
-875.15921 \\
1930.72122 \\
-136.47726 \\
219.08308 \\
-971.61023\end{array}$ & $\begin{array}{r}5.84337 \\
19.05205 \\
67.90978 \\
763.45913 \\
950.22622 \\
1187.57250 \\
46.84610 \\
169.23942 \\
5680.79985\end{array}$ & $\begin{array}{r}0.01455 \\
C .06573 \\
0.12612 \\
-0.08072 \\
-0.08493 \\
c .19271 \\
-c .28732 \\
0.15185\end{array}$ & $\begin{array}{rr}0.166 & 0.8098 \\
0.806 & 0.6222 \\
1.506 & 0.1352 \\
-0.906 & 0.3671 \\
-0.912 & 0.3636 \\
1.026 & 0.1068 \\
-2.913 & 0.0043 \\
1.2995 & 0.1981 \\
-0.111 & 0.8665\end{array}$ \\
\hline
\end{tabular}

\section{ANALYSIS OF VARIANCE}

$\begin{array}{lcrrr}\text { REGRESSION } & \text { SH } & \text { SUM OF SOUARES } & \text { MEAM SOUARE } \\ \text { RESIOUAL } & 114 & 165071709.79052 & \text { S9383963.72382 } \\ & & \end{array}$

$$
f=4.12769 \quad \text { Signif } F=0.0002
$$

for ulock number, all requesteo variables entered. 


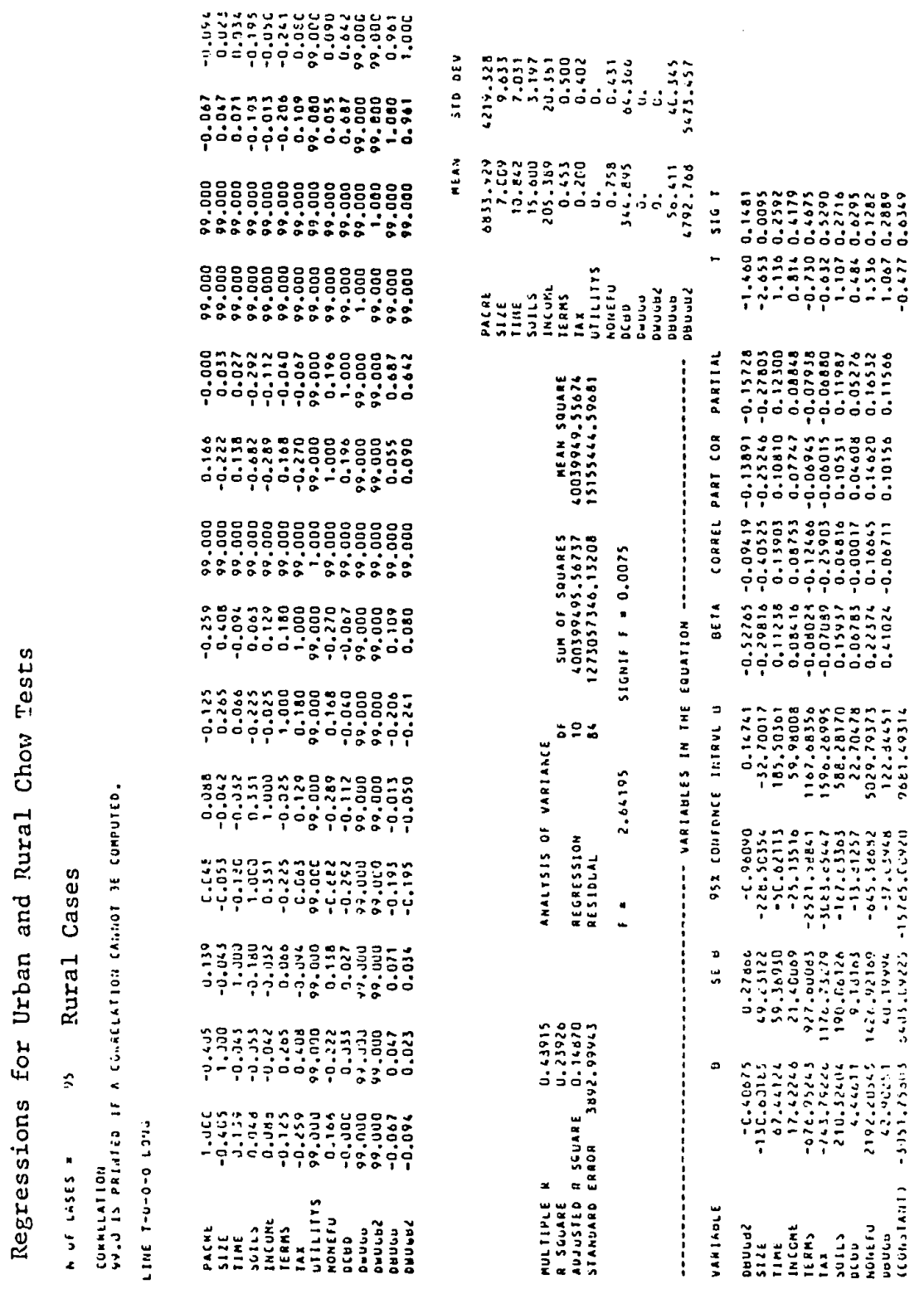


Urban Cases MULTIPLE REGRESSION SALEN UGB

$11-28-83$

GILE NOHAME (CREATION OATE : $\mid 1-28-83)$

-... nultiple regkession ....

Equation Rumaea 1.

DEPENOENT VARIABL:.. PACRE

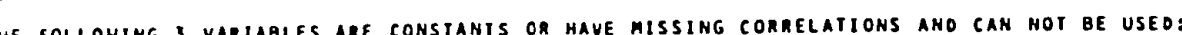

THE FOLLOWING 3 VARTABLES

BEGSANING QLOCK RURBEA T. METHOD: ERTER

WARIAULE (S) ENTERED ON STEP NUABEA

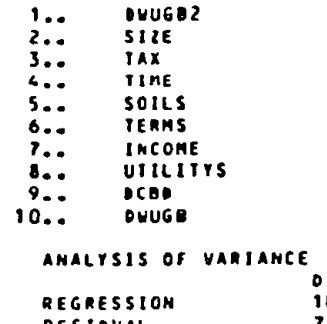

MULTIPLE R 0.50898

a souare square 0.2570

\begin{tabular}{|c|c|c|c|c|}
\hline & • & SE 8 & IEIA & 5160 \\
\hline $\begin{array}{l}\text { OUUGBZ } \\
\text { SIIE } \\
\text { IAX } \\
\text { JIAE } \\
\text { SOILS } \\
\text { JERMS } \\
\text { INCOME } \\
\text { UYILIIYS } \\
\text { OCBO } \\
\text { ONUGE } \\
\text { (CONSTANT) }\end{array}$ & $\begin{array}{r}-0.21515 \\
-95.98967 \\
-885.89540 \\
303.20028 \\
142.13242 \\
-841.23045 \\
-8.31667 \\
1715.27073 \\
-11.31819 \\
30.89110 \\
8891.12123\end{array}$ & $\begin{array}{r}0.63539 \\
67.07972 \\
3120.06274 \\
80.06263 \\
220.00686 \\
1226.86276 \\
26.016470 \\
2053.91962 \\
26.03603 \\
57.15684 \\
8903.26453\end{array}$ & $\begin{array}{r}-0.16162 \\
-0.18110 \\
-0.03026 \\
0.611308 \\
0.05133 \\
-C .07155 \\
-0.03315 \\
0.116068 \\
-C .09519 \\
0.181129\end{array}$ & 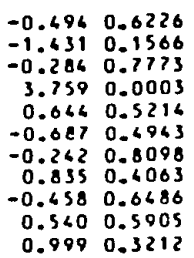 \\
\hline
\end{tabular}

AOJusTe R SQUARE 4057.15790
- 2.59658 SIGNIF $=0.0093$ 
IEANS AND STANDARD DEVIATIONS OF PDEGRESIONS REPORTED IN TEXT

$\begin{array}{lrr}\text { Urban-Rural } & \mathrm{n}=209 & \\ & \text { MEA.S } & \text { STD DEV } \\ \text { PACKE } & 8553.105 & 5140.640 \\ \text { SIZE } & 7.262 & 9.383 \\ \text { TIME } & 10.457 & 7.320 \\ \text { SOILS } & 15.370 & 3.225 \\ \text { IHCUHE } & 210.105 & 23.265 \\ \text { TEEHS } & 0.440 & 0.498 \\ \text { TAX } & 0.134 & 0.341 \\ \text { UTILITYS } & 0.287 & 0.453 \\ \text { NONEFU } & 0.459 & 0.500 \\ \text { OCLU } & 302.431 & 34.71 .7 \\ \text { UGUAOJ } & 0.411 & 0.493\end{array}$

Rural Nortin $\mathrm{n}=42$

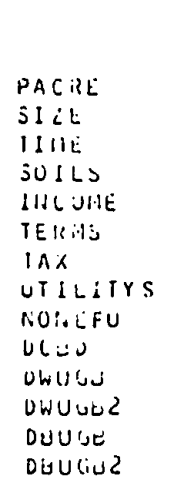

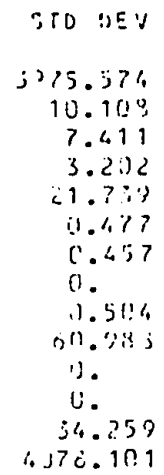

Urban North $n=40$

\begin{tabular}{|c|c|c|}
\hline & "IEA:I & STO CEV \\
\hline PAC:?E & $121: 35.740$ & 4750.051 \\
\hline$S I \angle E$ & 1.736 & 13.037 \\
\hline TI 1 的 & 9.1375 & 7.650 \\
\hline SÜIL & 20.000 & $1.67 \%$ \\
\hline linc cint & $1 \% 4.325$ & 10.203 \\
\hline IEFIis & Q.j;0 & $\mathrm{C}^{2} .4 .33$ \\
\hline TAX & $3.2 \geq 5$ & L . 153 \\
\hline UIILIIYS & C. & 0.374 \\
\hline NOR.EFU & J. & $\tilde{L}$ \\
\hline OCUO & $21 \% .775$ & 35.675 \\
\hline Cพบい: & $? 1.150$ & 20.0 .57 \\
\hline Chive & $: 1: 4.550$ & $1,27.172$ \\
\hline DUUUS & ก. & 0 \\
\hline DUUGUC & 0. & 0 . \\
\hline
\end{tabular}

Zura1 South $\mathrm{n}=53$

PACRE
SILE
TIME
SOILS
INCOME
TERMS
TAX
UTILITYS
NONEFU
DCBD
DWUGB
DWUGBZ
OBUGB
DBUGGL

MEAN

STO DEV

6883.717

6.728

11.000

13.792

198.566

0.547

0.132

0 .

1.000

364.226

0 .

0.

54.660

4959.868

4440.086

9.326

6.782

1.691

16.460

0.503

0.342

0 .

0.
60.787

0 .

44.833

6401.482

Urban South $n=46$

\begin{tabular}{|c|c|c|}
\hline & "EAN & STO DEV \\
\hline FACRE & 10036.288 & 5776.539 \\
\hline$S 12 E$ & 0.675 & 0.053 \\
\hline TIIIE & 9.717 & 7.122 \\
\hline SOILS & 14.000 & 1.757 \\
\hline INCONE & 227.543 & 27.634 \\
\hline TERPS & C.500 & 1). 500 \\
\hline $\operatorname{IAX}$ & $0.0 \% 3$ & 0.2116 \\
\hline UTILITYS & C. 522 & 0.505 \\
\hline AÜIIEFU & 0 & 0 \\
\hline DCUU & 240.234 & 1.4 .434 \\
\hline OHUGB & 49.304 & 30.427 \\
\hline DWU GU2 & 3778.543 & 5053.420 \\
\hline UUUGL & 0 & 0 \\
\hline ouviuz & $C$. & 0. \\
\hline
\end{tabular}




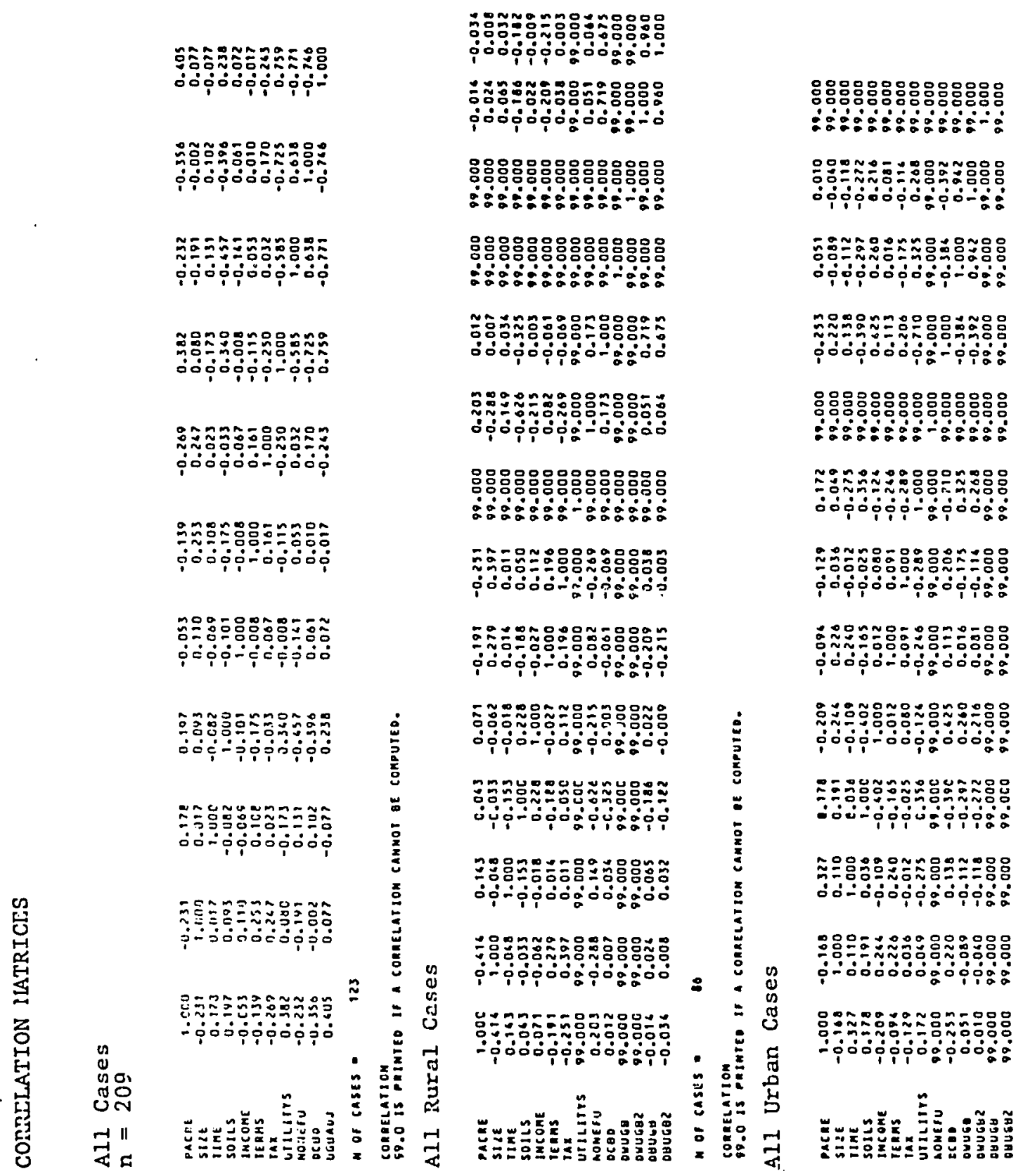


Rural iNorth

A Uf cKSES =

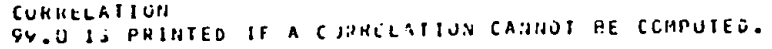

GHE t-u-0-0 Lor.:

\begin{tabular}{|c|c|c|c|c|c|}
\hline PACHE & 1.000 & -0.440 & 0.220 & $0.30 ?$ & -0.020 \\
\hline $51<t$ & $-0.4,40$ & ن נ. & -J.311 & $\begin{array}{l}-2.041 \\
-9, \pi, 6\end{array}$ & $\begin{array}{r}0.013 \\
-0.103\end{array}$ \\
\hline $\mathrm{TIHE}$ & $0.22 t$ & $-0 . \$ 11$ & 1.1300 & $-2.24 i c$ & -0.103 \\
\hline sults & $0.3 C ?$ & -0.341 & -3.240 & 1.uLC & 0.1176 \\
\hline INCUAit & $-0.1) 3 c$ & U.J13 & -3.1113 & $\begin{array}{r}0.07 t \\
-0.181\end{array}$ & 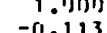 \\
\hline IEKMS & $-0 .: 113$ & U.c?! & $-0.0 \$ 7$ & -0.181 & $\begin{array}{l}-0.113 \\
-11.013\end{array}$ \\
\hline $\operatorname{tax}$ & -0.273 & $40 \div 23$ & -77.169 & -0.126 & $\begin{array}{l}-4.0 \mathrm{~J} 22 \\
99.000\end{array}$ \\
\hline WILAYS & $99.1) \cap \mathrm{C}$ & $99 . .1,16$ & 99.0013 & $99.00 \mathrm{C}$ & $\begin{array}{l}99.000 \\
-0.0 \times 9\end{array}$ \\
\hline nolvefu & 0.324 & -0.370 & 0.227 & $\begin{array}{l}-0.5<c \\
-5.385\end{array}$ & $\begin{array}{r}-0.089 \\
0.229\end{array}$ \\
\hline 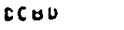 & $-0.11 ?$ & 0.167 & U. 124 & $-C .2 \varepsilon[$ & 0.229 \\
\hline & $97 . J \mathrm{JC}$ & $79 . J 30$ & 49.0 & $99 . \operatorname{ccc}$ & 99.000 \\
\hline 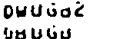 & $\begin{array}{c}99.00 \mathrm{C} \\
0.1 \div 1\end{array}$ & $\begin{array}{r}94 . j J u E \\
0.0 \geqslant 3\end{array}$ & $\begin{array}{r}99.000 \\
0.260\end{array}$ & $\begin{array}{l}48.000 \\
-0.6005\end{array}$ & $\begin{array}{r}99.000 \\
0.176\end{array}$ \\
\hline & & & & & \\
\hline
\end{tabular}

ouvitas $\begin{array}{ll}0.1001 & 0.023 \\ 0.070\end{array}$

$0.212 \quad-0.533$
0

0.226

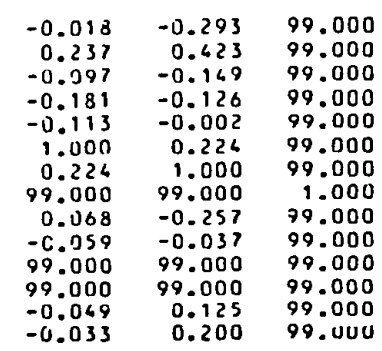

$\begin{array}{rrr}0.329 & -0.117 & 99.000 \\ -0.376 & 0.147 & 99.000 \\ 0.227 & 0.129 & 99.000 \\ -0.540 & -0.280 & 99.000 \\ -0.089 & 0.229 & 99.000 \\ 0.068 & -0.059 & 99.000 \\ -0.257 & -0.037 & 99.000 \\ 99.000 & 99.000 & 99.000 \\ 1.000 & -0.039 & 99.000 \\ -0.039 & 1.000 & 99.000 \\ 99.000 & 99.000 & 1.000 \\ 99.000 & 99.000 & 99.000 \\ 0.198 & 0.063 & 99.000 \\ 0.180 & 0.594 & 99.000\end{array}$

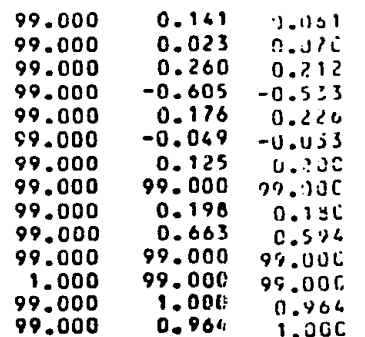

n or CASES -

53

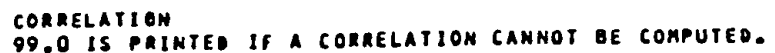

LINE T-O-O-O LONE

Rural South

\begin{tabular}{|c|c|c|c|c|c|c|c|c|c|c|c|c|c|c|}
\hline $\begin{array}{l}\text { ACRE } \\
\text { ILE } \\
\text { IME } \\
\text { OILS } \\
\text { NCOME } \\
\text { ERMS } \\
\text { AX } \\
\text { JILITYS } \\
\text { ONEFU } \\
\text { CBD } \\
\text { NUGB } \\
\text { UUGOZ } \\
\text { UUGS } \\
\text { OUGQ }\end{array}$ & $\begin{array}{r}1.000 \\
-0.382 \\
0.073 \\
0.176 \\
0.271 \\
-0.206 \\
-0.261 \\
99.000 \\
99.000 \\
0.076 \\
99.000 \\
99.000 \\
-0.179\end{array}$ & $\begin{array}{r}-0.382 \\
1.000 \\
0.208 \\
-0.196 \\
-0.161 \\
0.313 \\
0.399 \\
99.000 \\
99.000 \\
-0.038 \\
99.000 \\
99.000 \\
0.002\end{array}$ & $\begin{array}{r}0.073 \\
0.208 \\
1.000 \\
-0.097 \\
0.066 \\
0.0192 \\
-0.025 \\
99.000 \\
99.000 \\
-0.076 \\
99.000 \\
99.000 \\
-0.050 \\
-0.003\end{array}$ & $\begin{array}{l}6 \\
7 \\
6 \\
5 \\
5 \\
10 \\
0 \\
7 \\
0 \\
0 \\
1\end{array}$ & $\begin{array}{r}0.271 \\
-0.114 \\
0.066 \\
0.230 \\
1.000 \\
0.236 \\
0.156 \\
99.000 \\
99.0000 \\
-0.201 \\
99.000 \\
99.0000 \\
-0.206 \\
-0.221\end{array}$ & $\begin{array}{l}0.206 \\
0.313 \\
0.192 \\
0.045 \\
0.236 \\
1.000 \\
0.243 \\
9.000 \\
9.000 \\
0.171 \\
9.000 \\
9.000 \\
0.289 \\
0.367\end{array}$ & $\begin{array}{r}-0.269 \\
0.3399 \\
-0.0225 \\
0.015 \\
0.155 \\
0.263 \\
1.000 \\
99.000 \\
99.0000 \\
0.035 \\
99.000 \\
99.000 \\
0.090 \\
0.023\end{array}$ & $\begin{array}{l}99.000 \\
99.000 \\
99.001 \\
99.000 \\
99.000 \\
99.000 \\
99.000 \\
99.000 \\
99.000 \\
99.000 \\
99.000 \\
99.000 \\
99.000 \\
99.000\end{array}$ & $\begin{array}{l}9.000 \\
9.000 \\
9.000 \\
9.000 \\
9.000 \\
9.000 \\
9.000 \\
9.000 \\
1.000 \\
9.000 \\
9.000 \\
9.000 \\
9.000 \\
9.000\end{array}$ & $\begin{array}{r}0.076 \\
-0.038 \\
-0.076 \\
0.167 \\
-0.201 \\
-0.171 \\
0.035 \\
99.000 \\
99.000 \\
1.000 \\
99.000 \\
99.000 \\
0.810 \\
0.732\end{array}$ & & & $\begin{array}{r}-0.179 \\
0.062 \\
-0.050 \\
0.001 \\
-0.204 \\
-0.289 \\
0.090 \\
99.000 \\
99.000 \\
0.810 \\
99.000 \\
99.000 \\
1.000 \\
0.969\end{array}$ & \\
\hline
\end{tabular}


Urban Ilorth

uf lases =

CURnelation

LIHE $1-0-0-0$ LJ:I J

\begin{tabular}{|c|c|c|c|c|c|c|c|c|c|c|c|c|c|}
\hline 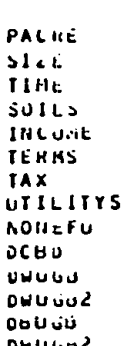 & $\begin{array}{r}1.000 \\
-0.1184 \\
0.505 \\
0.242 \\
-0.046 \\
0.042 \\
-0.078 \\
0.0258 \\
99.000 \\
-0.315 \\
0.455 \\
0.548 \\
94.000\end{array}$ & 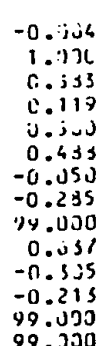 & $\begin{array}{r}0.365 \\
0.333 \\
1.000 \\
0.673 \\
. .375 \\
0.255 \\
0.109 \\
-0.059 \\
99.000 \\
0.310 \\
-9.124 \\
-0.011 \\
99.090 \\
99.000\end{array}$ & 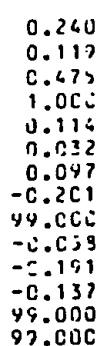 & $\begin{array}{r}-0.241 \\
0.550 \\
0.373 \\
0.116 \\
1.000 \\
0.257 \\
0.267 \\
-0.571 \\
99.030 \\
0.588 \\
-0.566 \\
-0.451 \\
99.000 \\
99.000\end{array}$ & $\begin{array}{r}0.042 \\
0.483 \\
0.255 \\
0.032 \\
0.257 \\
1.000 \\
-0.118 \\
-0.105 \\
99.006 \\
0.176 \\
-0.122 \\
-0.061 \\
99.000 \\
99.000\end{array}$ & $\begin{array}{r}-0.078 \\
-0.050 \\
0.109 \\
0.097 \\
0.207 \\
-0.118 \\
-1000 \\
-0.480 \\
99.000 \\
0.0328 \\
-0.098 \\
-0.093 \\
99.000 \\
99.000\end{array}$ & $\begin{array}{r}0.258 \\
-0.285 \\
-0.359 \\
-0.201 \\
-0.571 \\
-0.105 \\
-0.0480 \\
1.000 \\
99.000 \\
-0.061 \\
0.255 \\
0.198 \\
99.000 \\
99.000\end{array}$ & $\begin{array}{l}99.000 \\
99.000 \\
99.000 \\
99.000 \\
99.000 \\
99.000 \\
99.000 \\
99.000 \\
1.000 \\
99.000 \\
99.000 \\
99.000 \\
99.000 \\
99.000\end{array}$ & $\begin{array}{r}-0.315 \\
0.637 \\
0.380 \\
-0.058 \\
0.588 \\
0.176 \\
0.328 \\
-0.041 \\
99.000 \\
1.000 \\
-0.355 \\
-0.262 \\
99.000 \\
99.000\end{array}$ & $\begin{array}{r}0.465 \\
-0.305 \\
-0.124 \\
-0.191 \\
-0.506 \\
-0.122 \\
-0.098 \\
0.255 \\
99.000 \\
-0.355 \\
1.000 \\
0.955 \\
99.000 \\
99.000\end{array}$ & $\begin{array}{r}0.548 \\
-0.213 \\
-0.011 \\
-0.137 \\
-0.451 \\
-0.061 \\
-0.093 \\
0.198 \\
99.000 \\
-0.262 \\
0.955 \\
1.000 \\
99.000 \\
99.000\end{array}$ & $\begin{array}{l}99.000 \\
99.000 \\
99.000 \\
99.000 \\
99.000 \\
99.000 \\
99.000 \\
99.000 \\
99.000 \\
99.000 \\
99.000 \\
99.000 \\
1.000 \\
99.000\end{array}$ \\
\hline
\end{tabular}

h uf cAses =

40

CORRELATION

LINE T-0-0-0 LONG

Urban South

\begin{tabular}{|c|c|c|c|c|c|c|c|c|c|c|c|c|c|}
\hline 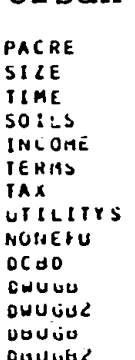 & $\begin{array}{r}1.000 \\
-0.022 c \\
0.3112 \\
-0.166 \\
-0.066 \\
-0.161 \\
-0.1140 \\
0.036 \\
99.06 c \\
-0.111 \\
0.061 \\
-0.021 \\
99.00 c \\
99.000\end{array}$ & $\begin{array}{r}-0.420 \\
1.030 \\
-0.370 \\
0.135 \\
0.416 \\
-0.033 \\
0.179 \\
0.254 \\
09.250 \\
-0.012 \\
0.172 \\
0.135 \\
0.03130 \\
90.0100\end{array}$ & $\begin{array}{r}0.311 \\
-0.370 \\
1.000 \\
-0.311 \\
-0.400 \\
0.230 \\
-0.0497 \\
-0.295 \\
99.000 \\
0.000 \\
-0.120 \\
-0.175 \\
99.000 \\
99.000\end{array}$ & $\begin{array}{r}-c .164 \\
0.135 \\
-c .111 \\
1.6 c c \\
0.351 \\
-0.147 \\
-0.000 \\
0.098 \\
99.06 c \\
c . c 65 \\
0.085 \\
0.055 \\
99.060 \\
99.060\end{array}$ & $\begin{array}{r}-0.006 \\
0.616 \\
-0.106 \\
0.151 \\
1.000 \\
-0.271 \\
-0.016 \\
0.383 \\
99.000 \\
0.788 \\
0.256 \\
0.117 \\
99.000 \\
99.000\end{array}$ & $\begin{array}{l}-0.141 \\
-0.083 \\
0.230 \\
-0.167 \\
-0.271 \\
1.000 \\
0.0213 \\
-0.261 \\
99.030 \\
-0.034 \\
-0.002 \\
0.064 \\
99.000 \\
99.000\end{array}$ & $\begin{array}{r}-0.166 \\
0.179 \\
-0.097 \\
-0.000 \\
-0.0160 \\
0.213 \\
1.0000 \\
-0.223 \\
99.000 \\
0.1162 \\
-0.247 \\
-0.157 \\
99.000 \\
99.000\end{array}$ & $\begin{array}{r}0.036 \\
0.256 \\
-0.295 \\
0.098 \\
0.383 \\
-0.261 \\
-0.223 \\
9.000 \\
99.000 \\
-0.053 \\
0.627 \\
0.521 \\
99.000 \\
99.000\end{array}$ & $\begin{array}{l}99.000 \\
99.000 \\
99.000 \\
99.000 \\
99.000 \\
99.000 \\
99.000 \\
99.000 \\
9.000 \\
99.000 \\
99.000 \\
99.000 \\
99.000 \\
99.000\end{array}$ & $\begin{array}{r}-0.111 \\
-0.012 \\
0.000 \\
0.065 \\
0.068 \\
-0.034 \\
0.142 \\
-0.053 \\
99.000 \\
1.000 \\
-0.772 \\
-0.776 \\
99.000 \\
99.000\end{array}$ & $\begin{array}{r}0.001 \\
0.192 \\
-0.120 \\
0.085 \\
0.256 \\
-0.002 \\
-0.247 \\
0.627 \\
99.000 \\
-0.772 \\
1.000 \\
0.951 \\
99.000 \\
99.000\end{array}$ & $\begin{array}{r}-0.021 \\
0.138 \\
-0.175 \\
0.055 \\
0.117 \\
0.066 \\
-0.157 \\
0.521 \\
99.000 \\
-0.776 \\
0.951 \\
1.000 \\
99.000 \\
99.000\end{array}$ & $\begin{array}{l}99.000 \\
99.000 \\
99.000 \\
99.000 \\
99.000 \\
99.000 \\
99.000 \\
99.000 \\
99.000 \\
99.000 \\
99.000 \\
99.000 \\
99.000 \\
99.000\end{array}$ \\
\hline
\end{tabular}




\section{A11 Urban and Rural Cases}

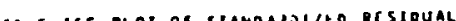

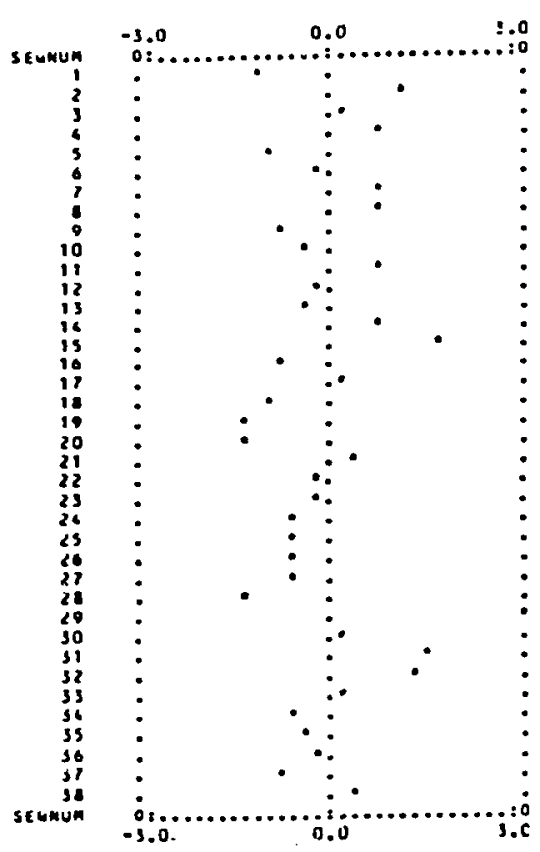

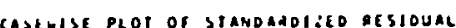
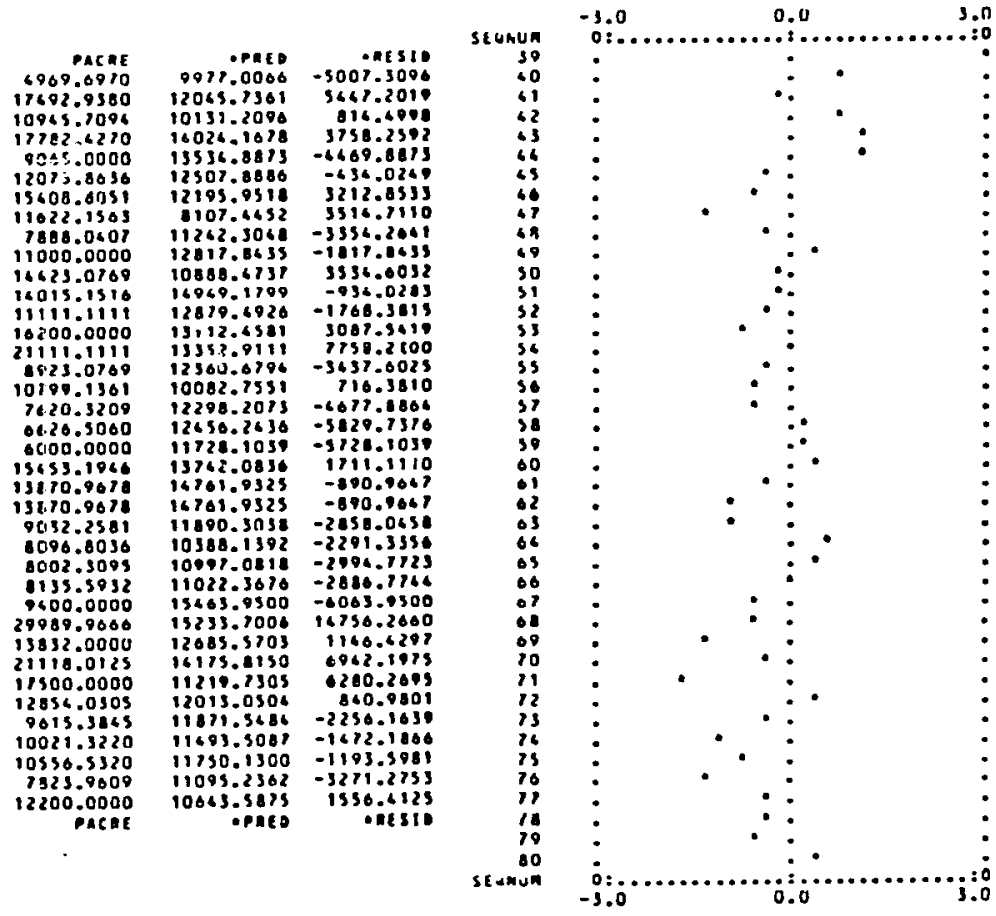

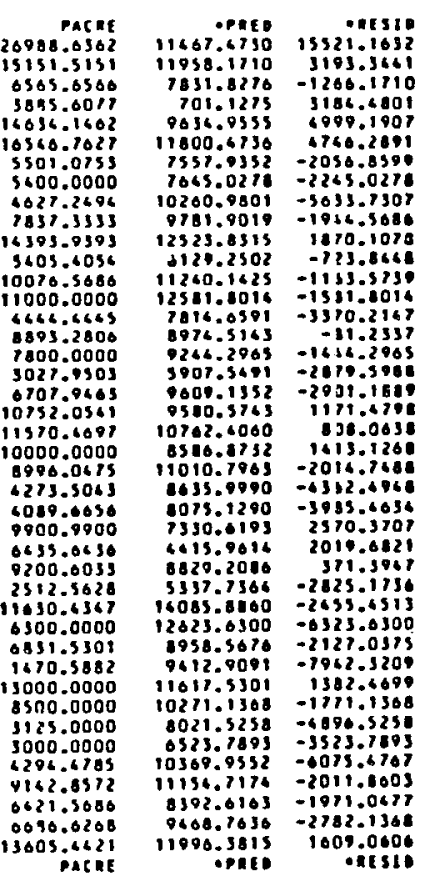


CASEUISE PLOS OR STALGARDILED HESTUUAL

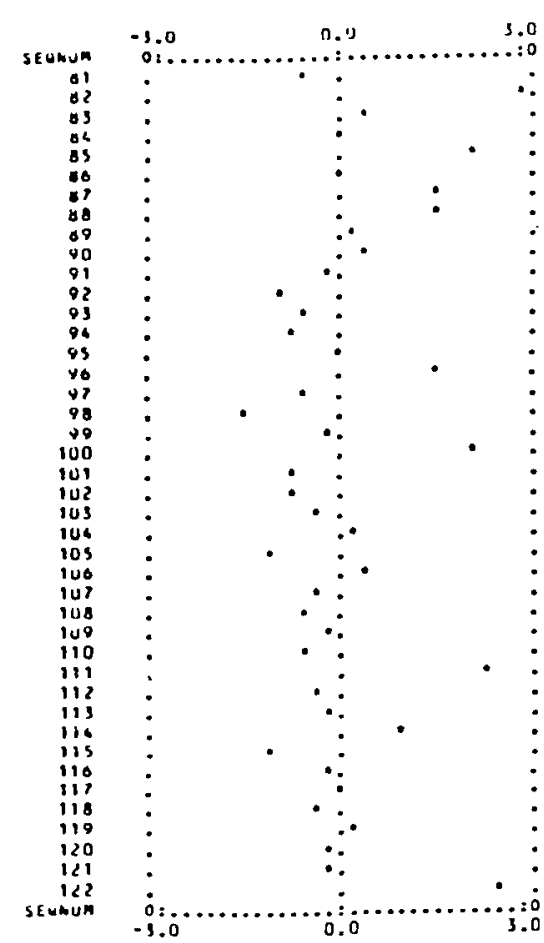

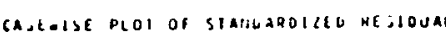
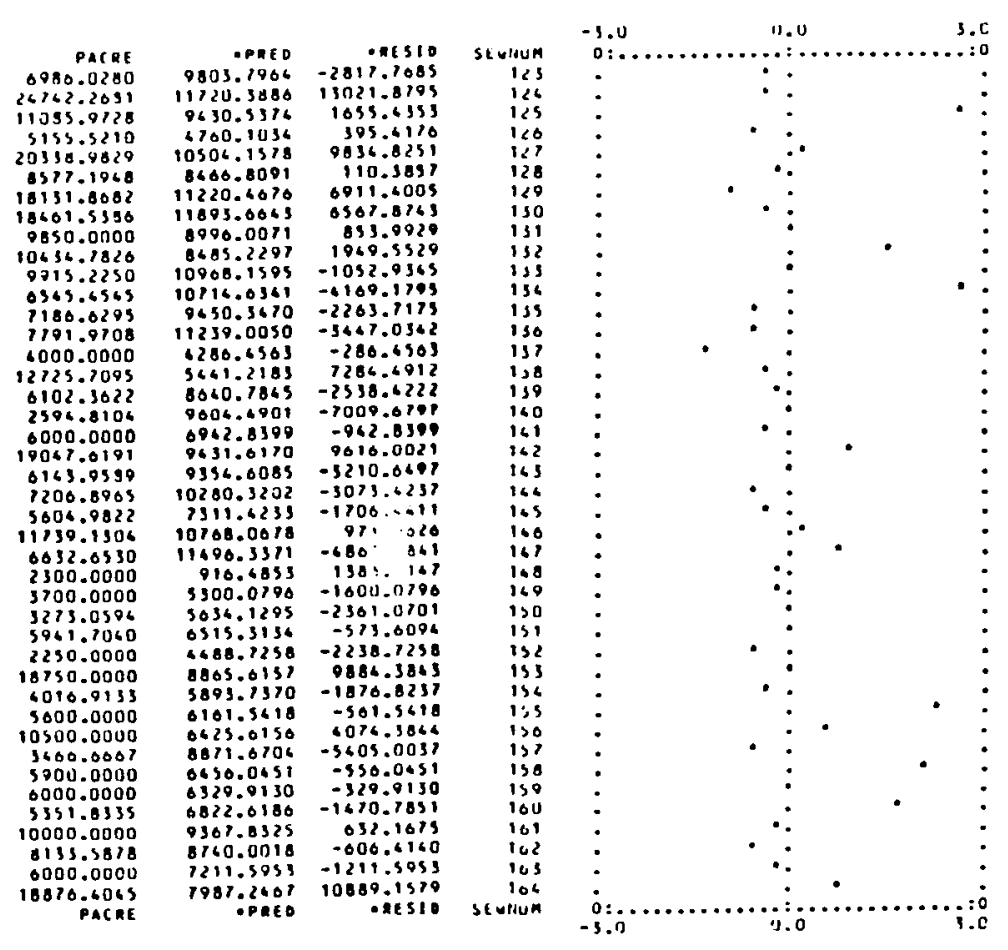
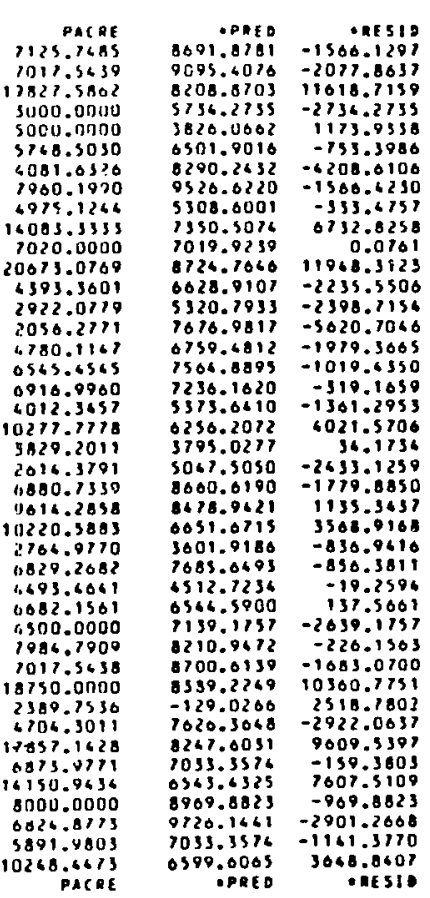
128

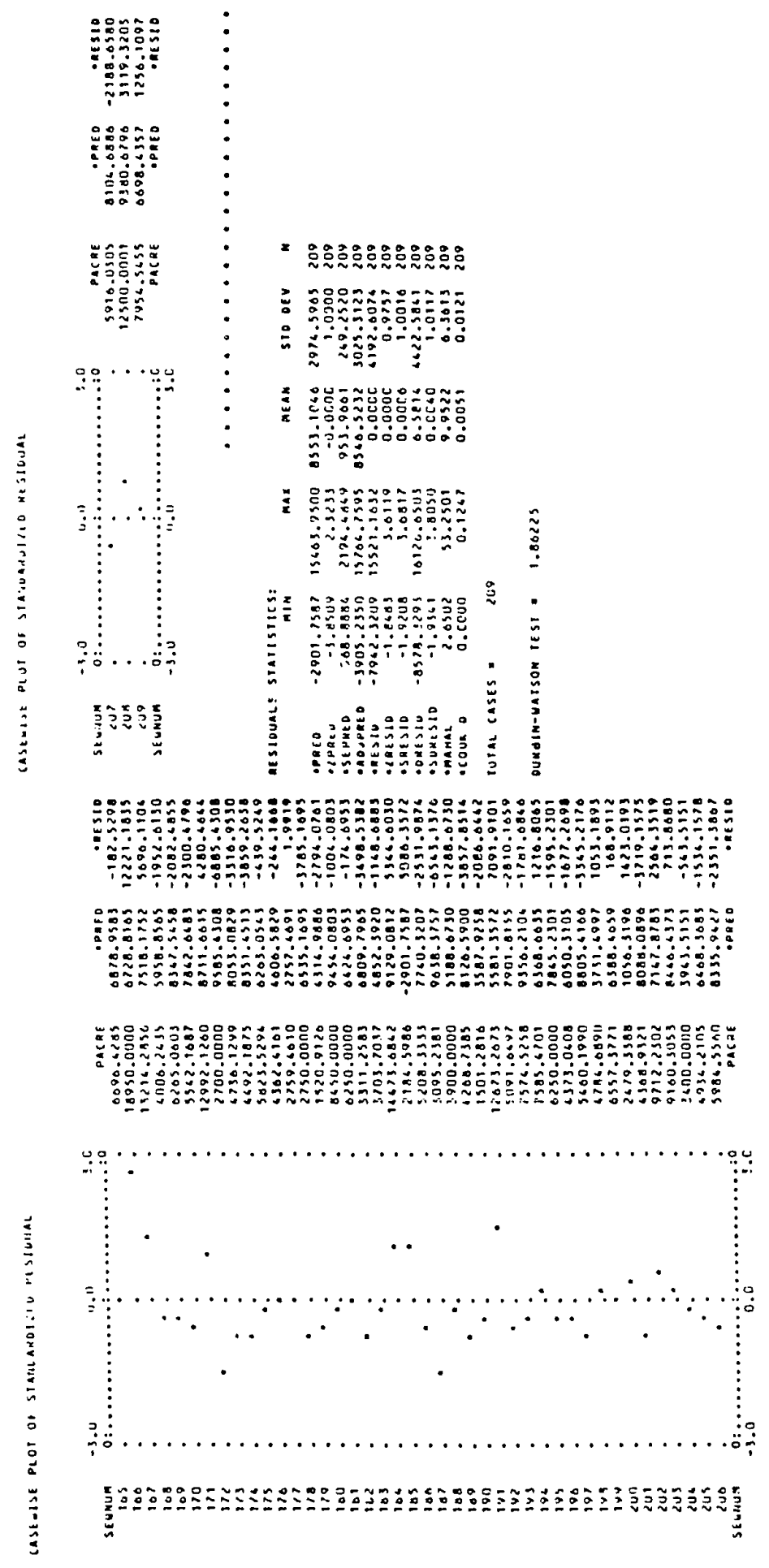




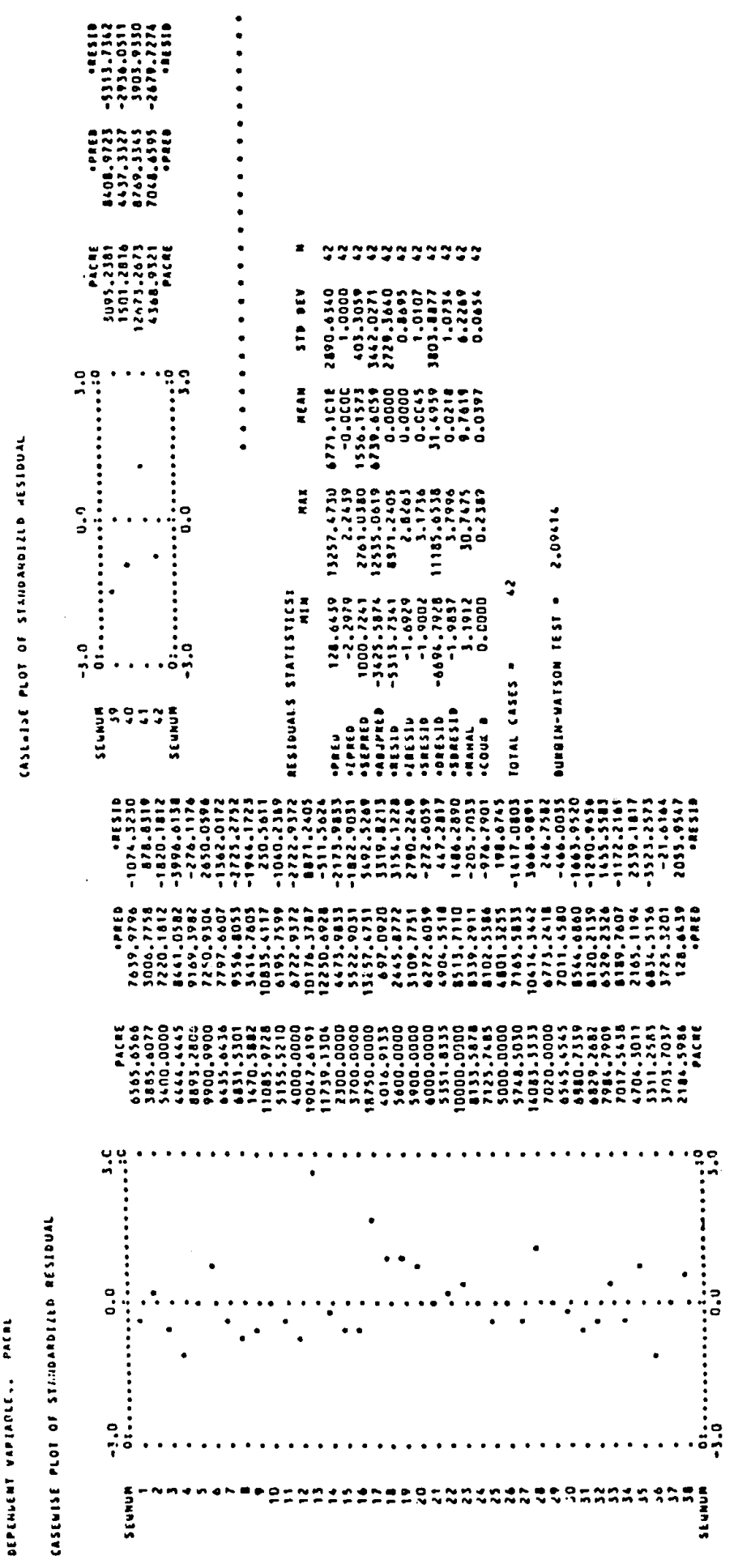



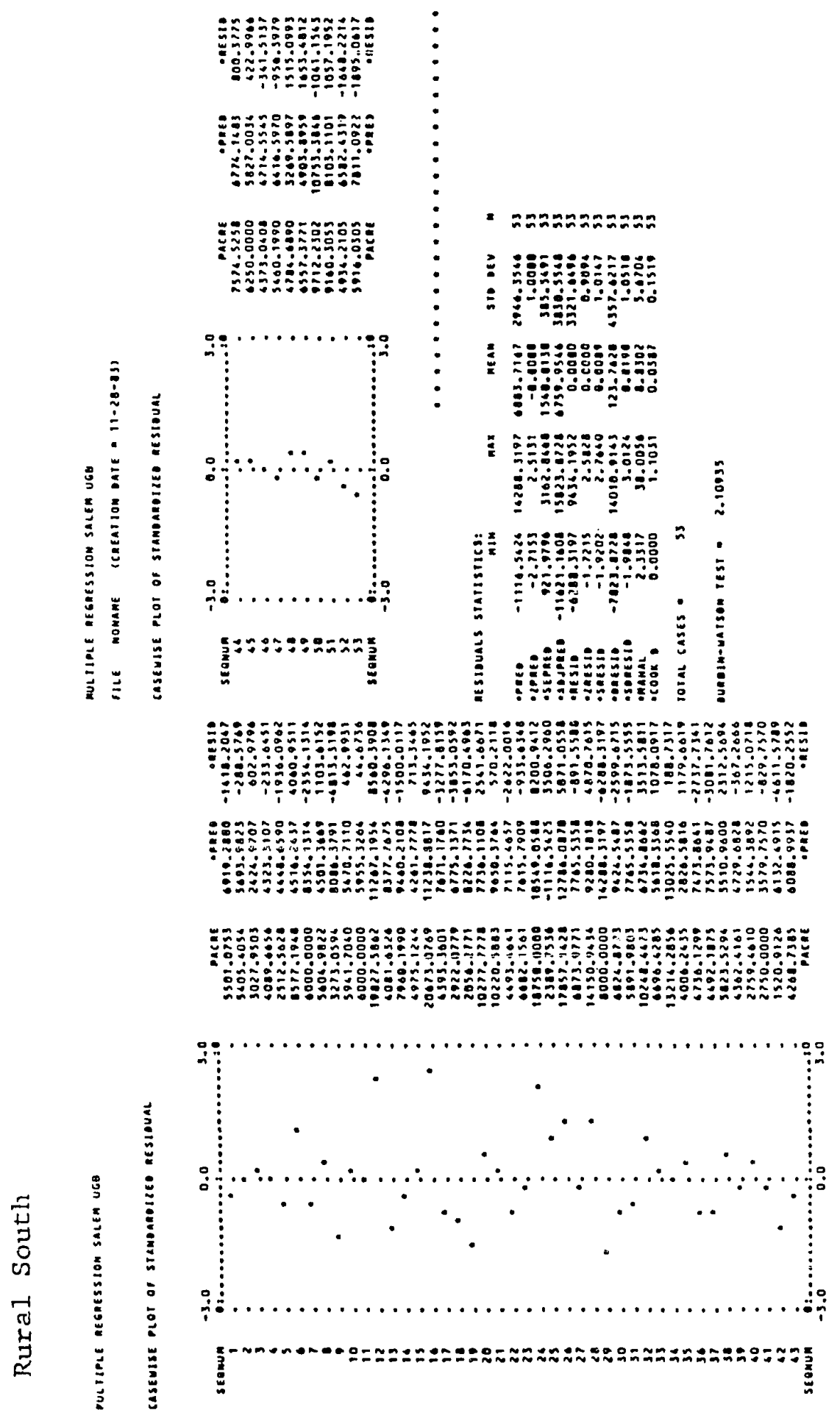


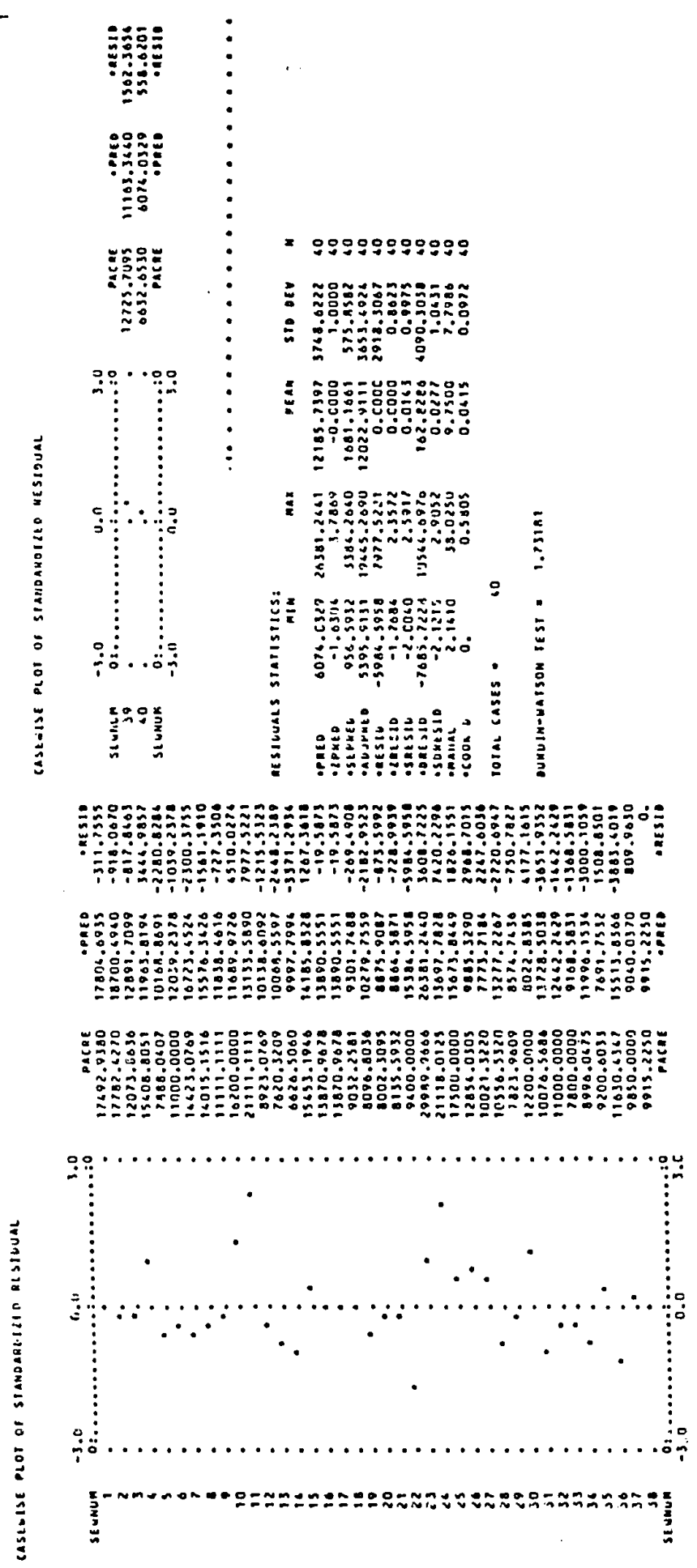



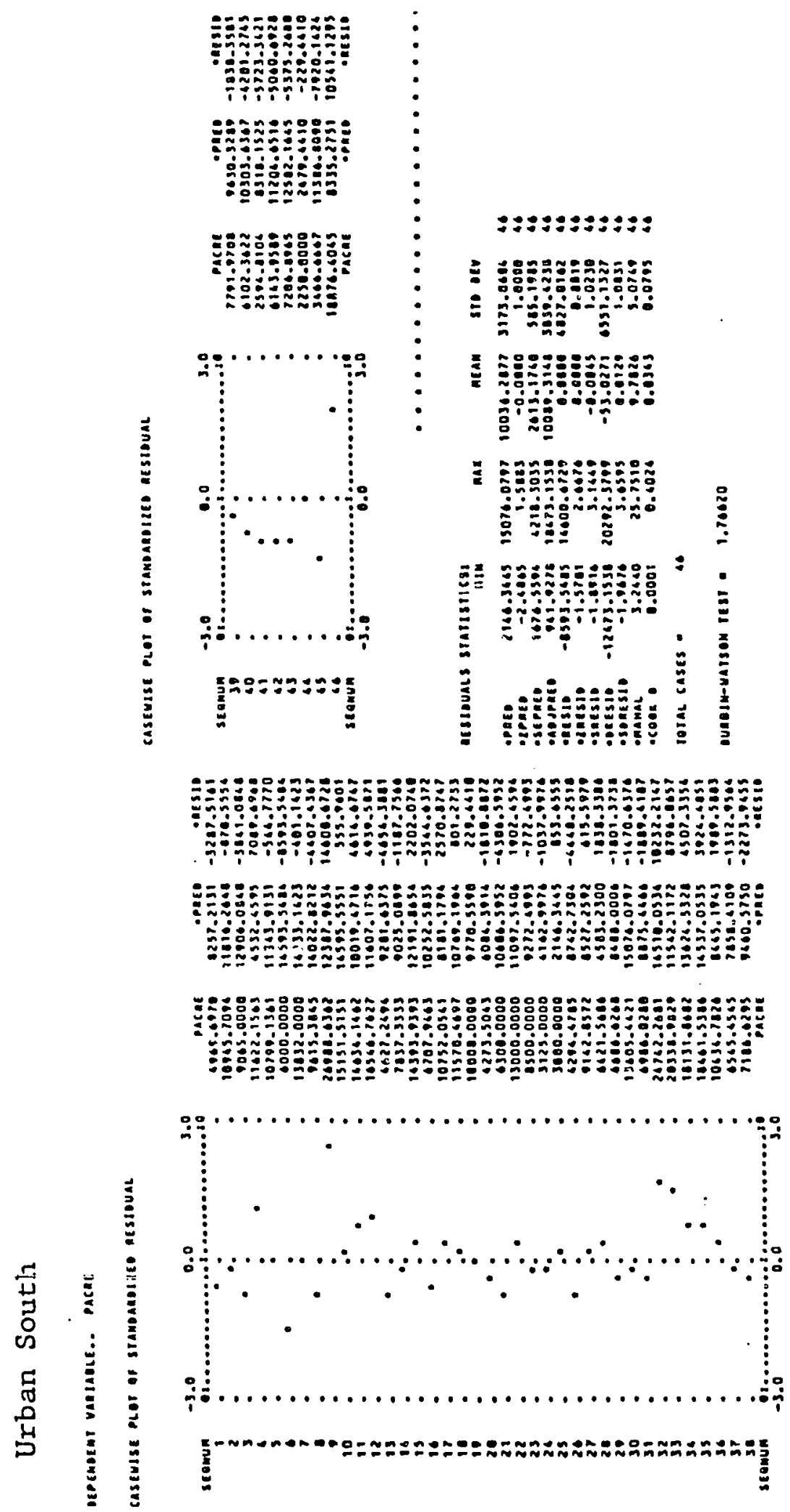


\section{Al1 Cases}

N OF CASES $=209$

COHRLLATION

LINE I-U-0-O LOAI

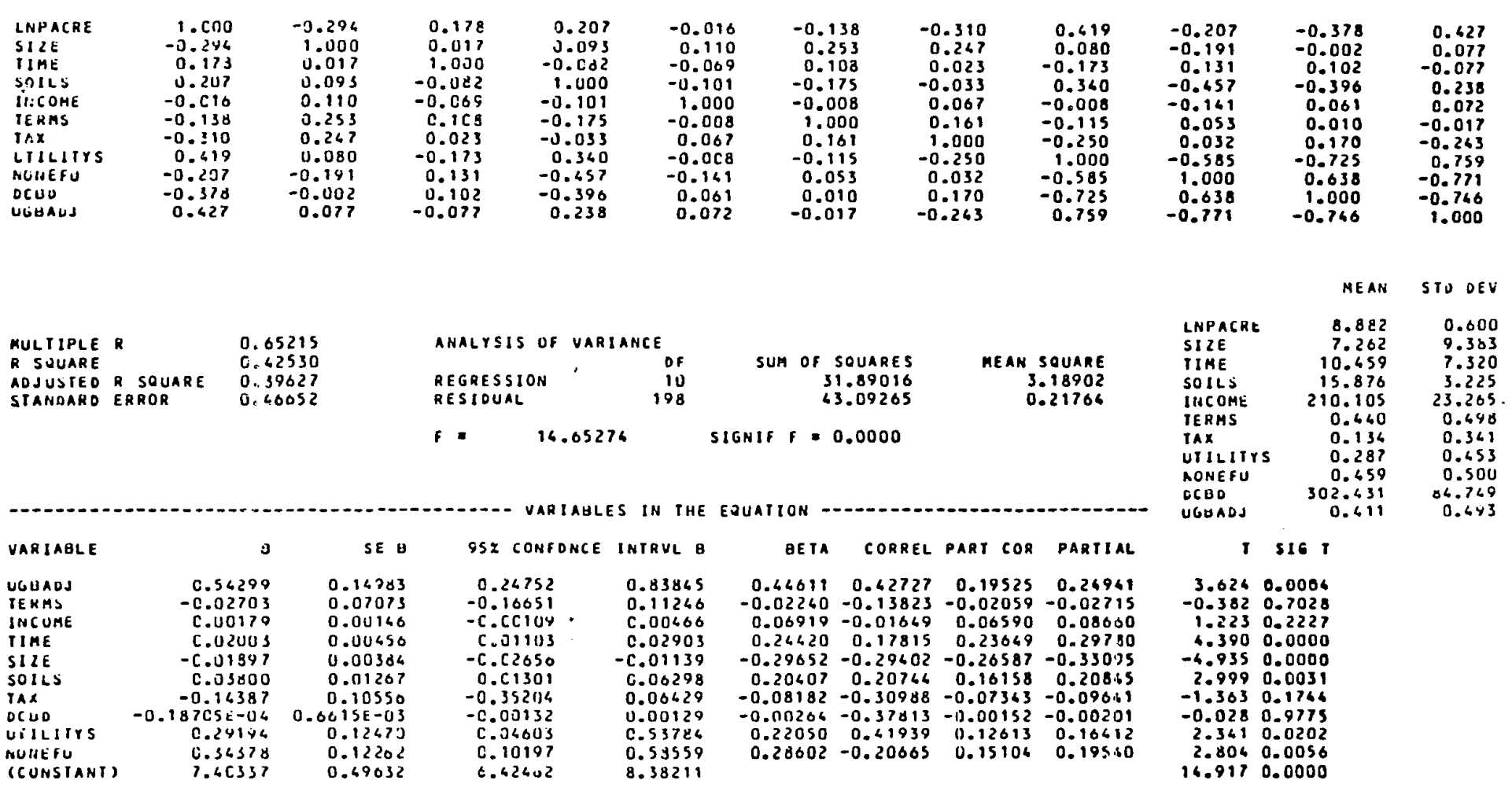

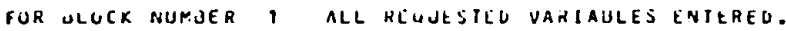




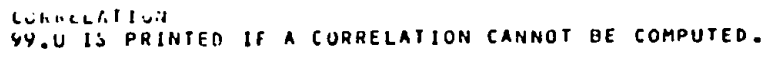

RURAL NORTH

\begin{tabular}{|c|c|c|c|c|c|}
\hline 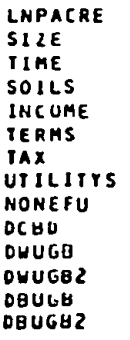 & $\begin{array}{r}1.000 \\
-0.556 \\
0.030 \\
-0.086 \\
-0.071 \\
0.003 \\
-0.275 \\
90.000 \\
0.422 \\
-0.167 \\
99.000 \\
19.000 \\
0.158 \\
0.096\end{array}$ & $\begin{array}{r}-0.558 \\
1.000 \\
-0.311 \\
-0.061 \\
0.013 \\
0.237 \\
0.023 \\
99.000 \\
-0.376 \\
0.1147 \\
99.000 \\
99.000 \\
0.023 \\
0.070\end{array}$ & $\begin{array}{r}0.230 \\
-0.311 \\
1.1100 \\
-1.290 \\
-0.103 \\
-0.097 \\
-0.149 \\
99.000 \\
0.227 \\
0.129 \\
99.000 \\
99.000 \\
0.260 \\
0.212\end{array}$ & $\begin{array}{l}-0.084 \\
-0.061 \\
-0.200 \\
1.06 c \\
0.076 \\
-c .181 \\
-0.126 \\
99.060 \\
-0.540 \\
-0.226 \\
99.000 \\
99.060 \\
-0.605 \\
-0.533\end{array}$ & $\begin{array}{r}-0.071 \\
0.013 \\
-0.103 \\
0.076 \\
1.000 \\
-0.113 \\
-0.002 \\
99.000 \\
-0.089 \\
0.229 \\
99.000 \\
99.000 \\
0.176 \\
0.226\end{array}$ \\
\hline
\end{tabular}

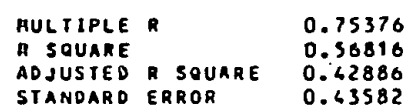

ANALYSIS OF VARIANCE

ADJUSTED R SOUARE

0.62886

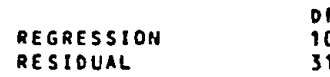

Sun of saunnes
7.76685
5.88810

REAN SOUARE
0.77669
0.78994

$F=4.07801$

SIGNIF: $=0.0012$

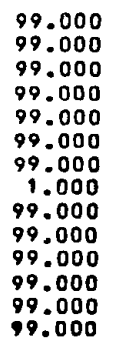

0.622
-0.376
0.227
-0.560
-0.089
0.068
-0.257
99.000
9.000
-0.059
99.000
99.000
0.198
0.180

$\begin{array}{rr}-0.167 & 99.000 \\ 0.167 & 99.000 \\ 0.129 & 90.000 \\ -0.280 & 99.000 \\ 0.229 & 99.000 \\ -0.059 & 99.000 \\ -0.037 & 99.000 \\ 99.000 & 99.000 \\ -0.039 & 99.000 \\ 1.000 & 99.000 \\ 99.000 & 9.000 \\ 99.000 & 99.000 \\ 0.663 & 99.060 \\ 0.596 & 99.000\end{array}$

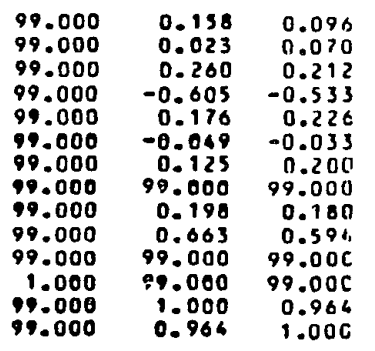

REAN STI DEY

\begin{tabular}{|c|c|}
\hline 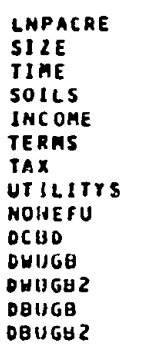 & 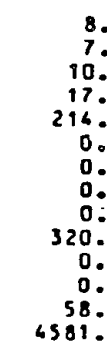 \\
\hline tof CASES & $s=$ \\
\hline$T$ & 3161 \\
\hline $\begin{array}{r}-2.205 \\
1.306 \\
2.119 \\
0.049 \\
0.326 \\
-0.270 \\
-1.859 \\
-2.806 \\
2.352 \\
3.041 \\
6.011\end{array}$ & $\begin{array}{l}0.0350 \\
0.1818 \\
0.0622 \\
0.9610 \\
0.7670 \\
0.7886 \\
0.0725 \\
0.0080 \\
0.0252 \\
0.0068 \\
0.0000\end{array}$ \\
\hline
\end{tabular}

$\begin{array}{rr}8.865 & 0.577 \\ 7.366 & 10.108\end{array}$

\begin{tabular}{l}
$.643 \quad 7.41$ \\
\hline .928
\end{tabular}

$16.000 \quad 21.739$

$\begin{array}{ll}0.323 & 0.677 \\ 0.280 & 0.457\end{array}$

$0.452 \quad 0.505$

0. 0.

34.259
4078.101

42

\begin{tabular}{|c|c|c|c|c|c|c|c|c|c|c|}
\hline ARIAGLE & y & SE $B$ & 95X CONFD & DNCE INTRVL $B$ & BETA & CORREL & PART COR & PARTIAL & & 3161 \\
\hline $\begin{array}{l}\text { OQUGGZ } \\
\text { IERAS } \\
\text { NONEFU } \\
\text { INCCME } \\
\text { TINE } \\
\text { IAX } \\
\text { SLLE } \\
\text { OCGO } \\
\text { SUILS } \\
\text { OHUGO } \\
\text { (COHSTANT) }\end{array}$ & $\begin{array}{r}-0.10761 E-03 \\
C .21191 \\
0.43100 \\
0.102385-03 \\
C .00340 \\
-0.05063 \\
-0.01608 \\
-0.00477 \\
0.07170 \\
0.03153 \\
7.28253\end{array}$ & $\begin{array}{r}.7592 E-06 \\
0.15513 \\
0.20338 \\
0.00342 \\
0.01066 \\
0.18719 \\
0.00397 \\
0.00170 \\
0.03877 \\
0.01037 \\
1.01158\end{array}$ & $\begin{array}{r}-0.32224 E-03 \\
-c .10648 \\
0 . c 1620 \\
-c . c c 080 \\
-C . c 1792 \\
-0.43240 \\
-0 . c 3697 \\
-0 . c c 825 \\
c . c 1212 \\
0.61039 \\
4 . d 1150\end{array}$ & $\begin{array}{r}-0.12573 E-04 \\
0.52831 \\
0.86580 \\
0.00716 \\
0.02473 \\
0.33115 \\
0.00162 \\
-0.00130 \\
0.17026 \\
0.05268 \\
9.75356\end{array}$ & $\begin{array}{r}-1.18386 \\
0.17533 \\
0.37650 \\
0.00635 \\
0.04374 \\
-0.06016 \\
-0.29232 \\
-0.550492 \\
0.50635 \\
1.87307\end{array}$ & $\begin{array}{r}0.09557 \\
0.00307 \\
0.42245 \\
-0.07103 \\
0.23004 \\
-0.27653 \\
-0.55753 \\
-0.16699 \\
-0.08392 \\
0.15818\end{array}$ & $\begin{array}{r}-0.26026 \\
0.16122 \\
0.25012 \\
0.00582 \\
0.03862 \\
-0.03192 \\
-0.21965 \\
-0.33089 \\
0.27760 \\
0.35887\end{array}$ & $\begin{array}{r}-0.36822 \\
0.23827 \\
0.35572 \\
0.00885 \\
0.05837 \\
-0.06852 \\
-0.31675 \\
-0.46974 \\
0.38914 \\
0.47929\end{array}$ & $\begin{array}{r}-2.205 \\
1.306 \\
2.199 \\
0.069 \\
0.326 \\
.0 .270 \\
-1.859 \\
-2.804 \\
2.352 \\
3.061 \\
6.011\end{array}$ & $\begin{array}{l}0.0350 \\
0.1818 \\
0.0622 \\
0.9610 \\
0.7670 \\
0.7886 \\
0.0725 \\
0.0080 \\
0.0252 \\
0.0068 \\
0.0000\end{array}$ \\
\hline
\end{tabular}




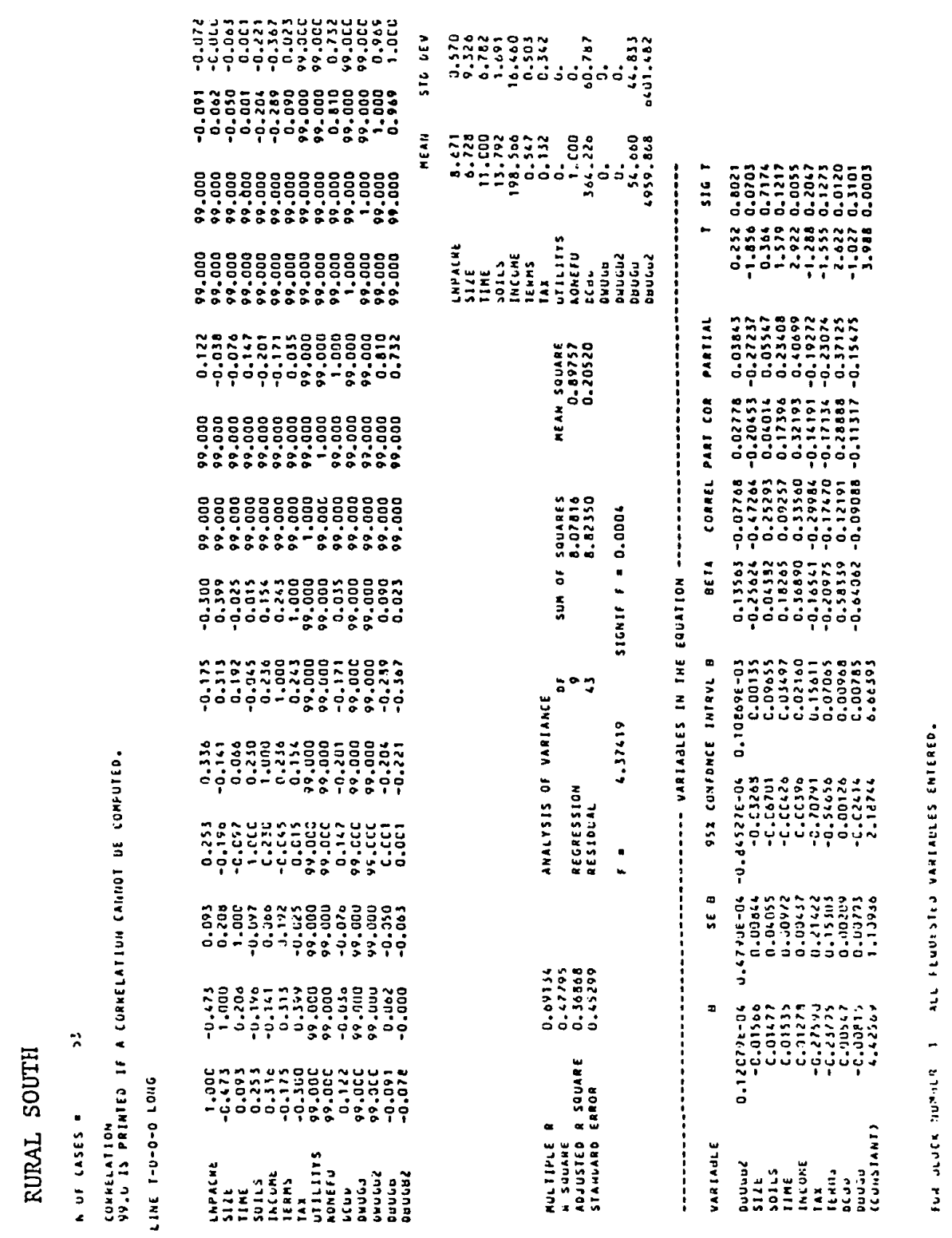


Urban North

n of cases :

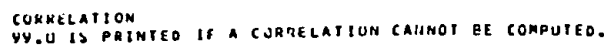

LINE T-U-0-O LONG

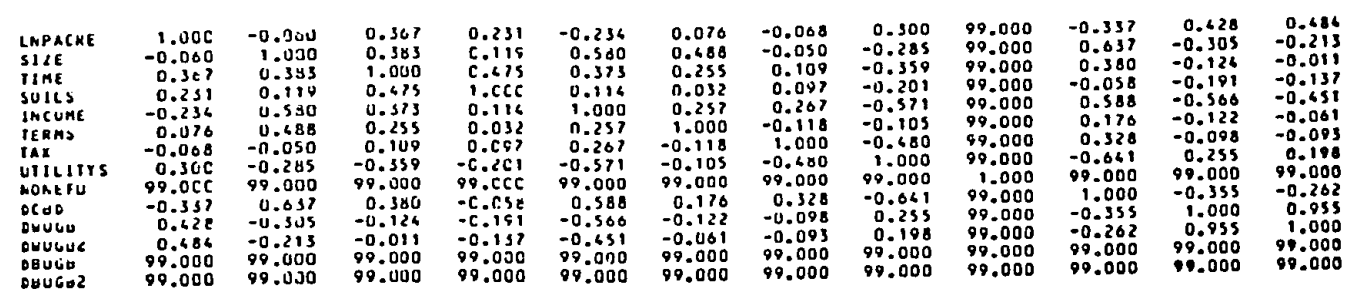

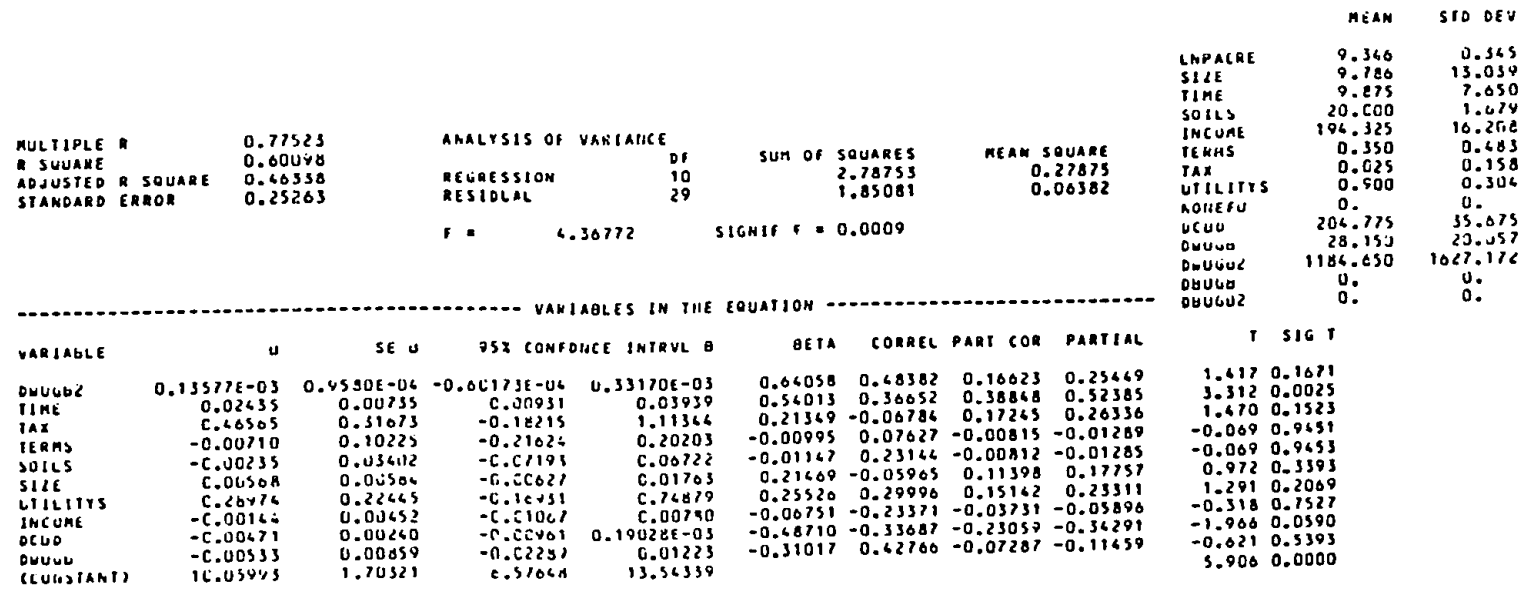




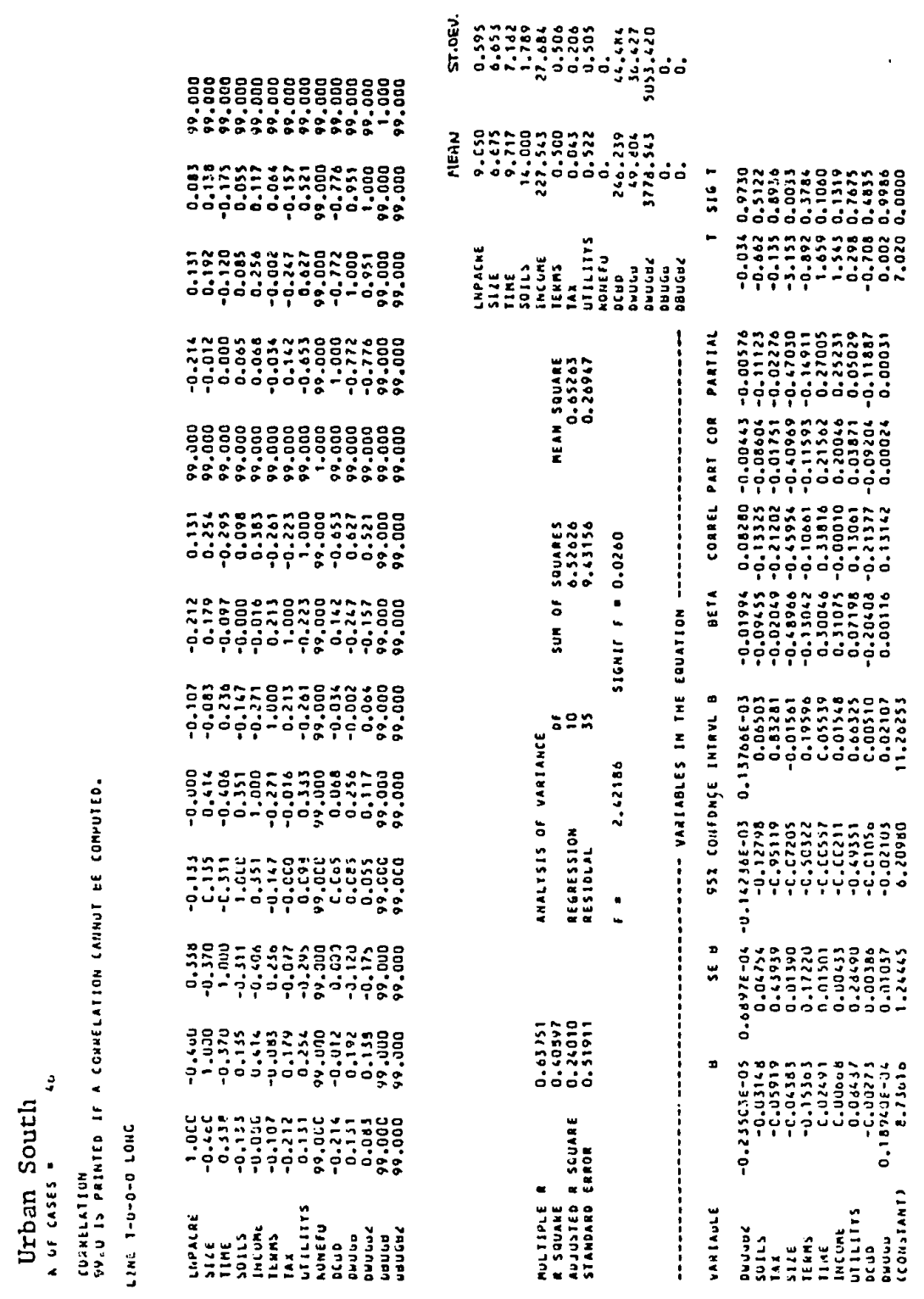

